NYPL RESEARCH LIBRARIES 




$$
\text { . }
$$




\section{.}


Digitized by the Internet Archive in 2008 with funding from Microsoft Corporation 


$$
\int \mu, a n=\frac{704}{R_{10}}
$$



$4 \frac{2}{2}=4:=$ 

THE EAGLE'S NEST 



\title{
THE EAGLE'S NEST
}

\section{TEN LECTURES}

\author{
ON THE RELATION OF
}

NATURAL SCIENCE TO ART

\author{
GIVEN BEFORE THE UNIVERSITY OF OXFORD \\ IN LENT TERM, I872
}

BY

JOHN RUSKIN, LL.D.

HONORARY STUDENT OF. CHRIJ̨T EHURCH, ANL HQNORARY FELLOW OF CORPUS CFAISII COLLEGE, JXFJRD

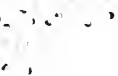

WITH AN INTRODGCTION BY CHARLES ELTOT NOFTON

NEW YORK, :"

Maynard, Merrill, \& Co., Publishers, 43, $45 \& 47$ EAst Tenth St. $\therefore$

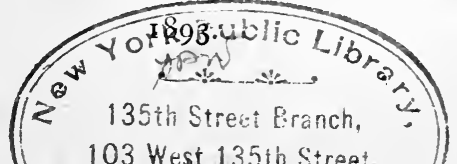




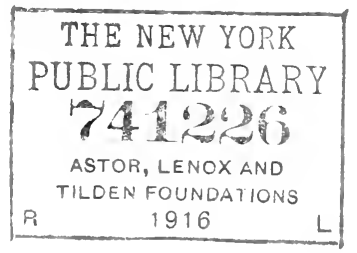

\section{SPECIAL ANNOUNCEMENT}

Mr. George Allen begs to announce that Ruskin's Works will hereafter be published in America by Messrs. Charles E. Merrill \& Co, of Nezw, York, who will issue the only authorized editions،

Copyright $189 \mathrm{r}$

Charles E. Merrill \& Co. 


\section{INTRODUCTION.}

THE ten Lectures which form this volume 1 were given before the University of Oxford in a single month, from February 8th to March 9th, 1872. In his Preface to them Mr. Ruskin says that they have been written, " not with less care, but with less pains than any in former courses," but that "the assertions I have made are entirely deliberate, though their terms are unstudied." In a letter written during the period of their delivery, on February I $3^{\text {th, he }}$ describes his work: "I am, as usual, unusually busy. When I get fairly into my lecture work at Oxford, I always find the lecture would come better some other way, just before it is given, and 
so work from hand to mouth. There are to be ten this spring. Two are given, and I have two a week for four weeks, on the relation of art to natural science, and am printing them as I go on,-besides" much other work.

It is not surprising that, prepared under such conditions, the Lectures have little of the character of an elaborate treatise, but are rather the free and unmethodical discourse of a man of genius on a general topic to which he had given much reflection, and with which his mind was full. They are to be regarded not so much as a carefully-compacted and well-ordered body of doctrine, as a looselystrung series of instructions, to be read with profit by the intelligent student, but often open to question, and seldom complete in their presentation of the subject under discussion.

The pages are rich in aphorisms on art and life; they abound in quotable sentences; 
they are not vacant of stimulating paradoxes, nor do they lack assertions which provoke dispute. The generous earnestness of the writer is apparent throughout; his scorn of prevailing habits of thought, his wrath with the moral deadness of his contemporaries, his contempt for the modern systems of education and theories of life.

Mr. Ruskin's mind towards the public in these times was settling more and more into a fixed temper of sad hopelessness. He had little comfort from his work at Oxford. Just a year before these Lectures were given, he wrote, "I am always unhappy, and see no good in saying so. But I am settling to my work here,-recklessly,-to do my best with it; feeling quite that it is talking at hazard, for what chance good may come. But I attend regularly in the schools as mere drawing-master, and the men begin to come one by one, about fifteen or twenty already; several worth having as pupils in any way, 
being of temper to make good growth of." Again, a week or two later he wrote: “I have an increasingly bitter sense of the total aberration from all right and wise rules of education in Oxford, and of the solitary voice that this art teaching may become for calmness and sacredness of life." And a little later still, in April I87I, he said: "At Oxford, having been Professor a year and a half, I thought it time to declare open hostilities with Kensington, and requested the Delegates to give me a room for a separate school on another system. They went with me altogether, and I am going to furnish my rear room with coins, books, drawings, engravings, and Greek vases. Then I am going to found a Teachership, on condition of the teaching being on such and such principles, and this whole spring I must work hard to bring all my forces well to bear, and show what I can do."

These plans were not the only projects 
that gave him occupation at this time. $\mathrm{He}$ had begun with the year the issue of his monthly appeals and addresses to the public, which, under the now well-known title of "Fors Clavigera," were for a long time to afford a vent for his most eager and strenuous thought on the aspects of society, on the reform of its evil conditions, on the fundamental principles of politics, and on many miscellaneous topics; and he was engaged also in establishing the St. George's Society, which he hoped might serve as an actual example and nucleus of practical reform in the modes of life of its members. "I can't do the tenth part of what I plan," he wrote in the course of the spring. "A heap of things that I ought to do nods over my head like a breaking wave."

He had been spending generously in money as well as time and energy in carrying out his designs. "I cannot afford to buy anything more, so set am I now on political work, 
as far as money is concerned." But not all his means were spent on politics: "I am going to give five thousand pounds to found the Mastership" (in the School at Oxford), "which will take the mechanical work off me, and block out Kensington. I've just finished Catalogue of those hundred pieces of Educational Series, and so on." At midsummer he wrote, "I am, drawing breath, after much disturbed work at Oxford."

But he was not to come off scot free from all this strain, and in July he was prostrated by a severe illness, in which for a time his life was at risk.

After his recovery a new interest added a new occupation to his days. "I have bought," he wrote in the middle of September, "a small place here" (Coniston, Lancashire), "with five acres of rock and moor, a streamlet, and I think on the whole the finest view I know in Cumberland or Lancashire, with the sunset visible over the same. The house small, old, 
damp, smoky-chimneyed, - somebody must help me to get to rights." This was Brantwood, henceforth to be his home. "Here I have rocks, streams, fresh air, and for the first time in my life the rest of the purposed home."

Meanwhile he had begun the publication of his Revised Works, the first volume of which, "Sesame and Lilies," had appeared in the spring, and the second volume, "Munera Pulveris," was in the press. "I am writing a word or two on Tintorct's work as true 'wealth' opposed to French lithographs and the like, in the preface; and Fors Clavigera is, I think, going on well. It takes more time than I like, but is beginning to make an impression."

In November he was "working very prosperously. About Christmas there (D.V.) will be a complete volume of Fors, a volume of Lectures on Sculpture, a volume of revised Political Economy, and a begun Natural 
History and Mythology of Birds, and the same of Fishes."

But at this time his mother was lying fatally ill. On December 5 th she died. $\mathrm{He}$ was left with a "surprising sense of loneliness;" a sense that was to increase rather than diminish as time went on. Her care of him and devotion to him had been more than the usual care of mothers, and he had repaid it with more than the usual devotion of sons. The precious continuity of more than fifty years of mutual dependence was broken, and with the change of home a new period was to begin, a period full of the ministries to him of faithful affection, but of increasing solitariness and gradually shortening and darkening days.

There was no intermission in his labours. Before the end of the year he was pursuing his varied courses of work with indefatigable energy. He had begun to write the Lectures contained in this volume. 
It would be strange if they did not show some signs of dispersed attention, of impatient ardour, of imperfect finish in thought and style. But whatever their failure in workmanship, there is no base metal in their composition; they bear the tower-stamp of sincerity.

C. E. N.

Cambridge, Massachusetts,

April I891. 



\section{PREFACE.}

THE following Lectures have been written, not with less care, but with less pains, than any in former courses, because no labour could have rendered them exhaustive statements of their subjects, and I wished, therefore, to take from them every appearance of pretending to be so: but the assertions I have made are entirely deliberate, though their terms are unstudied; and the one which to the general reader will appear most startling, that the study of anatomy is destructive to art, is instantly necessary in explanation of the system adopted for the direction of my Oxford schools.

At the period when engraving might have 
become to art what printing became to literature, the four greatest point-draughtsmen hitherto known, Mantegna, Sandro Botticelli, Dürer, and Holbein, occupied themselves in the new industry. All these four men were as high in intellect and moral sentiment as in artpower; and if they had engraved as Giotto painted, with popular and unscientific simplicity, would have left an inexhaustible series of prints, delightful to the most innocent minds, and strengthening to the most noble.

But two of them, Mantegna and Dürer, were so polluted and paralyzed by the study of anatomy that the former's best works (the magnificent mythology of the Vices in the Louvre, for instance) are entirely revolting to all women and children; while Dürer never could draw one beautiful female form or face; and, of his important plates, only four, the Melancholia, St. Jerome in his study, St. Hubert, and The Knight and Death, are of any use for popular 
instruction, because in these only, the figures being fully draped or armed, he was enabled to think and feel rightly, being delivered from the ghastly toil of bone-delineation.

Botticelli and Holbein studied the face first, and the limbs secondarily; and the works they have left are therefore (without exception) precious; yet saddened and corrupted by the influence which the contemporary masters of body-drawing exercised on them; and at last eclipsed by their false fame. I purpose, therefore, in my next course of lectures, to explain the relation of these two draughtsmen to other masters of design, and of engraving.

Brantwood. Sept. 2nd, 1872 . 



\title{
CONTENTS。
}

\author{
LECTURE I. \\ February 8, 1872.
}

THE FUNCTION IN ART OF THE FACULTY CALLED BY THE GREEKS $\sigma O \phi i ́ a . \quad$. . . . . . I

\section{LECTURE II.}

February 10, 1872.

THE FUNCTION IN SCIENCE OF THE FACULTY CALLED BY

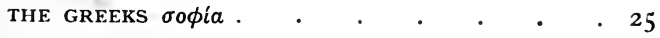

LECTURE III.

February 15, 1872.

THE RELATION OF WISE ART TO WISE SCIENCE • . 46

\section{LECTLRE IV.}

February 17, 1872.

THE FUNCTION IN ART AND SCIENCE OF THE VIRTUE CALLED BY THE GREEKS $\sigma \omega \phi \rho \sigma \sigma i ́ \nu \eta$ 


\section{LECTURE V.}

\section{February 22, 1872.}

THE FUNCTION IN ART AND SCIENCE OF THE VIRTUE

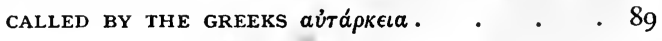

LECTURE VI.

February 24, 1872.

THE RELATION TO ART OF THE SCIENCE OF LIGHT . II4

LECTURE VII.

February 29, 1872.

THE RELATION TO ART OF THE SCIENCES OF INORGANIC FORM . . . . . . . . . 138

\section{LECTURE VIII.}

\section{March 2, 1872.}

THE RELATION TO ART OF THE SCIENCES OF ORGANIC FORM

LECTURE IX.

March 7, 1872.

INTRODUCTION TO ELEMENTARY EXERCISES IN PHYSIOLOGIC ART. THE STORY OF THE HALCYON • . I 88

LECTURE X.

March 9, 1872.

INTRODUCTION TO ELEMENTARY EXERCISES IN HISTORIC ART. THE HERALDIC ORDINARIES . . . . 225 


\title{
PROFERTY OF THE \\ CITY OF NEW YORK.
}

\section{THE EAGLE'S NEST.}

\author{
LECTURE I. \\ OF WISDOM AND FOLLY IN ART.*
}

8th February, 1872.

I. 'The Lectures I have given hitherto, though, in the matter of them conscientiously addressed to my undergraduate pupils, yet were greatly modified in method by my feeling that this undergraduate class, to which I wished to speak, was indeed a somewhat imaginary one; and that, in truth, I was addressing a mixed audience, in greater part composed of the masters of the University, before whom it was

* The proper titles of these lectures, too long for pageheadings, are given in the Contents. 
my duty to lay down the principles on which I hoped to conduct, or prepare the way for the conduct of, these schools, rather than to enter on the immediate work of elementary teaching. But to-day, and henceforward most frequently, we are to be engaged in definite, and, I trust, continuous studies; and from this time forward, I address myself wholly to my undergraduate pupils; and wish only that my Lectures may be serviceable to them, and, as far as the subject may admit of it, interesting.

2. And, farther still, I must ask even my younger hearers to pardon me if I treat that subject in a somewhat narrow, and simple way. They have a great deal of hard work to do in other schools: in these, they must not think that I underrate their powers, if I endeavour to make everything as easy to them as possible. No study that is worth pursuing seriously can be pursued without effort; but we need never make the effort painful merely for the sake of preserving our dignity. Also, I shall make my Lectures shorter than heretofore. What I tell you I wish you to remember; and I do not think it possible for you to remember well much more than I can easily tell you in half-an-hour. 
I will promise that, at all events, you shall always be released so well within the hour, that you can keep any appointment accurately for the next. You will not think me indolent in doing this; for, in the first place, I can assure you, it sometimes takes me a week to think over what it does not take a minute to say: and, secondly, believe me, the least part of the work of any sound art-teacher must be his talking. Nay, most deeply also, it is to be wished that, with respect to the study which I have to bring before you to-day, in its relation to art, namely, natural philosophy, the teachers of it, up to this present century, had done less work in talking, and more in observing: and it would be well even for the men of this century, pre-eminent and accomplished as they are in accuracy of observation, if they had completely conquered the old habit of considering, with respect to any matter, rather what is to be said, than what is to be known.

3. You will, perhaps, readily admit this with respect to science; and believe my assertion of it with respect to art. You will feel the probable mischief, in both these domains of intellect, which must follow on the desire rather to 
talk than to know, and rather to talk than to do. But the third domain, into the midst of which, here, in Oxford, science and art seem to have thrust themselves hotly, like intrusive rocks, not without grim disturbance of the anciently fruitful plain;-your Kingdom or Princedom of Literature? Can we carry our statement into a third parallelism, for that? It is ill for Science, we say, when men desire to talk rather than to know; ill for Art, when they desire to talk rather than to do. Ill for Literature, when they desire to talk,--is it ? and rather thanwhat else? Perhaps you think that literature means nothing else than talking?-that the triple powers of science, art, and scholarship, mean simply the powers of knowing, doing, and saying. But that is not so in any wise. The faculty of saying or writing anything well, is an art, just as much as any other; and founded on a science as definite as any other. Professor Max Müller teaches you the science of language; and there are people who will tell you that the only art I can teach you myself, is the art of it. But try your triple parallelism once more, briefly, and see if another idea will not occur to you. In science, you must not talk 
before you know. In art, you must not talk before you.do. In literature you must not talk before you-think.

That is your third Province. The Kingdom of Thought, or Conception.

And it is entirely desirable that you should define to yourselves the three great occupations of men in these following terms :-

Science. . . The knowledge of things, whether Ideal or Substantial.

ArT. ... The modification of Substantial things by our Substantial Power. Literature. The modification of Ideal things by our İdeảl Power.

4. But now observe. If this division be a just one, we ought to have a word for literature, with the 'Letter' left out of it. It is true that, for the most part, the modification of ideal things by our ideal power is not complete till it is expressed; nor even to ourselves delightful, till it is communicated. To letter it and label it-to inscribe and to word it rightly,-this is a great task, and it is the part of literature 
which can be most distinctly taught. But it is only the formation of its body. And the soul of it can exist without the body; but not at all the body without the soul; for that is true no less of literature than of all else in us or of us - "litera occidit, spiritus autem vivificat."

Nevertheless, I must be content to-day with our old word. We cannot say 'spiriture' nor 'animature,' instead of literature ; but you must not be content with the vulgar interpretation of the word. Remember always that you come to this University,-or, at least, your fathers came,- not to learn how to say things, but how to think them.

5. "How to think them! but that is only the art of logic," you perhaps would answer. No, again, not at all : logic is a method, not a power; and we have defined literature to be the modification of ideal things by ideal power, not by mechanical method. And you come to the University to get that power, or develop it ; not to be taught the mere method of using it.

I say you come to the University for this; and perhaps some of you are much surprised to hear it! You did not know that you came to the University for any such purpose. Nay, 
perhaps you did not know that you had come to a University at all ? You do not at this instant, some of you, I am well assured, know what a University means. Does it mean, for instance-can you answer me in a moment, whether it means-a place where everybody comes to learn something; or a place where somebody comes to learn everything? It means -or you are trying to make it mean-practically and at present, the first; but it means theoretically, and always, the last; a place where only certain persons come, to learn everything; that is to say, where those who wish to be able to think, come to learn to think: not to think of mathematics only, nor of morals, nor of surgery, nor chemistry, but of everything, rightly.

6. I say you do not all know this; and yet, whether you know it or not,-whether you desire it or not,-to some extent the everlasting fitness of the matter makes the facts conform to it. For we have at present, observe, schools of three kinds, in operation over the whole of England. We have-I name it first, though, I am sorry to say, it is last in influence-the body consisting of the Royal Academy, with 
the Institute of Architects, and the schools at Kensington, and their branches; teaching various styles of fine or mechanical art. We have, in the second place, the Royal Society, as a central body; and, as its satellites, separate companies of men devoted to each several science : investigating, classing, and describing facts with unwearied industry. And lastly and chiefly, we have the great Universities, with all their subordinate public schools, distinctively occupied in regulating,-as I think you will at once admit,- not the language merely, nor even the language principally, but the modes of philosophical and imaginative thought in which we desire that youth should be disciplined, and age informed and majestic. The methods of language, and its range; the possibilities of its beauty, and the necessities for its precision, are all dependent upon the range and dignity of the unspoken conceptions which it is the function of these great schools of literature to awaken, and to guide.

7. The range and dignity of conceptions! Let us pause a minute or two at these words, and be sure we accept them.

First, what is a conception? What is this 
separate object of our work, as scholars, distinguished from artists, and from men of science?

We shall discover this better by taking a simple instance of the three agencies.

Suppose that you were actually on the plain of Pæstum, watching the drift of storm-cloud which Turner has here engraved.* If you had occupied yourself chiefly in schools of science, you would think of the mode in which the electricity was collected; of the influence it had on the shape and motion of the cloud; of the force and duration of its flashes, and of other such material phenomena. If you were an artist, you would be considering how it might be possible, with the means at your disposal, to obtain the brilliancy of the light, or the depth of the gloom. Finally, if you were a scholar, as distinguished from either of these, you would be occupied with the imagination of the state of the temple in former times; and as you watched the thunderclouds drift past its columns, and the power of the God of the heavens put forth, as it seemed, in scorn of the departed power of the god who was thought by the heathen to shake the earth

* Educational Series, No. 8, E. 
- the utterance of your mind would become, whether in actual words or not, such as that of the Psalmist :-_"Clouds and darkness are round about Him_righteousness and judgment are the habitation of His throne." Your thoughts would take that shape, of their own accord, and if they fell also into the language, still your essential scholarship would consist, not in your remembering the verse, still less in your knowing that "judgment" was a Latin word, and "throne" a Greek one; but in your having power enough of conception, and elevation enough of character, to understand the nature of justice, and be appalled before the majesty of dominion.

8. You come, therefore, to this University, I repeat once again, that you may learn how to form conceptions of proper range or grasp, and proper dignity, or worthiness. Keeping then the ideas of a separate school of art, and separate school of science, what have you to learn in these? You would learn in the school of art, the due range and dignity of deeds; or doings-(I prefer the word to "makings," as more general), and in the school of science, you would have to learn the range and dignity of knowledges. 
Now be quite clear about this: be sure whether you really agree with me or not.

You come to the School of Literature, I say, to learn the range and dignity of conceptions.

To the School of Art, to learn the range and dignity of deeds.

To the School of Science, to learn the range and dignity of knowledges.

Do you agree to that, or not? I will assume that you admit my triple division; but do you think, in opposition to me, that a school of science is still a school of science, whatever sort of knowledge it teaches; and a school of art still a school of art, whatever sort of deed it teaches; and a school of literature still a school of literature, whatever sort of notion it teaches?

Do you think that? for observe, my statement denies that. My statement is, that a school of literature teaches you to have one sort of conception, not another sort; a school of art to do a particular sort of deed, not another sort; a school of science to possess a particular sort of knowledge, not another sort.

9. I assume that you differ with me on this point;-some of you certainly will. Well then, 
let me go back a step. You will all go thus far wit't me, that-now taking the Greek wordsthe school of literature teaches you to have vov̂s, or conception of things, instead of ávoca,-ro conception of things; that the school of art

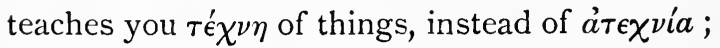
and the school of science $\dot{\epsilon} \pi \iota \tau \eta \dot{\mu} \eta$, instead of ärvoıa or 'ignorantia.' But, you recollect, Aristotle names two other faculties with these

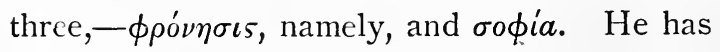

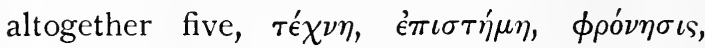
$\sigma o \phi i a, \nu o \hat{s}$; that is to say, in simplest English, -art, science, sense, wisdom, and wit. We have got our art, science, and wit, set over their three domains; and we old people send you young ones to those three sćhools, that you may not remain artless, scienceless, nor witless. But how of the sense, and the wisdom? What domains belong to these? Do you think our trefoil division should become cinquefoil, and that we ought to have two additional schools; one of Philosophia, and one of Philophronesia? If Aristotle's division were right it would be so. But his division is wrong, and he presently shows it is; for he tells you in the next page, (in the sentence I have so often quoted to you,) 
that "the virtue of art is the wisdom which consists in the wit of what is honourable." Now that is perfectly true; but it of course vitiates his division altogether. He divides his entire subject into $A, B, C, D$, and $E$; and then he tells you that the virtue of $A$ is the $B$ which consists in $C$. Now you will continually find, in this way, that Aristotle's assertions are right, but his divisions illogical. It is quite true that the virtue of art is the wisdom which consists in the wit of what is honourable; but also the virtue of science is the wit of what is honourable, and in the same sense, the virtue of vov̂s, or wit itself, consists in its being the wit or conception of what is honourable. $\Sigma o \phi i a$, therefore, is not only the $a \rho \epsilon \tau \eta^{\prime} \tau \epsilon^{\prime} \chi \nu \eta$, but, in exactly the same sense, the $\dot{a} \rho \tau \eta^{\prime} \dot{\epsilon} \pi \iota \sigma \tau \dot{\eta} \mu \eta \mathrm{s}$, and in this

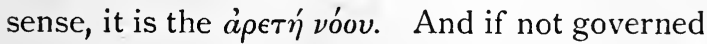
by $\sigma o \phi i ́ a$, each school will teach the vicious con-

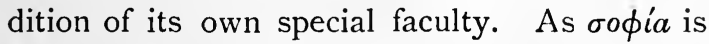

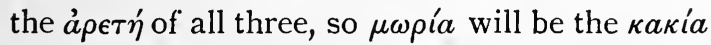
of all three.

IO. Now in this, whether you agree with me or not, let me be at least sure you understand

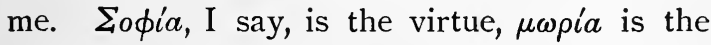
vice, of all the three faculties of art, science, and 
literature. There is for each of them a negative and a positive side, as well as a zero. There is a nescience for zero in science-with wise science on one side, foolish science on the other :

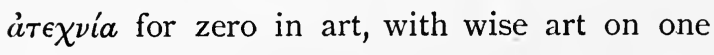
side, foolish art on the other; and ávoıa for zero in $\nu o \hat{s}$, with wise $\nu o \hat{s}$ on one side, foolish vov̂s on the other.

I I. You will smile at that last expression, ' foolish vovs.' Yet it is, of all foolish things, the commonest and deadliest. We continually complain of men, much more of women, for reasoning ill. But it does not matter how they reason, if they don't conceive basely. Not one person in a hundred is capable of seriously reasoning; the difference between man and man is in the quickness and quality, the accipitrine intensity, the olfactory choice, of his vov̂s. Does he hawk at game or carrion ? What you choose to grasp with your mind is the question; - not how you handle it afterwards. What does it matter how you build, if you have bad bricks to build with; or how you reason, if every idea with which you begin is foul or false? And in general all fatal false reasoning proceeds from people's having some one false notion in their 
hearts, with which they are resolved that their reasoning shall comply.

But, for better-illustration, I will now take my own special subject out of the three;-

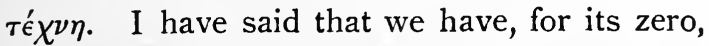

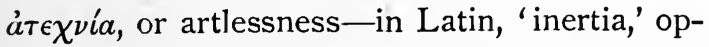
posed to 'ars.' Well, then, we have, from that zero, wise art on the one side, foolish art on the other ; and the finer the art, the more it is capable of this living increase, or deadly defect. I will take, for example, first, a very simple art, then a finer one; but both of them arts with which most of you are thoroughly acquainted.

12. One of the simplest pieces of perfect art, which you are yourselves in the habit of practising, is the stroke of an oar given in true time. We have defined art to be the wise modification of matter by the body (substantial things by substantial power, $\S 3$ ). With a good oar-stroke you displace a certain quantity of water in a wise way. Supposing you missed your stroke, and caught a crab, you would displace a certain quantity of water in a foolish way, not only ineffectually, but in a way the reverse of what you intended. 'The perfectness of the stroke implies not only 
absolutely accurate knowledge or science of the mode in which water resists the blade of an oar, but the having in past time met that resistance repeatedly with greater and greater rightness of adaptation to the end proposed. That end Deing perfectly simple,- - the advance of the boat as far as possible with a given expenditure of strength, you at once recognize the degree in which the art falls short of, or the artlessness negatives, your purpose. But your being бoфós,' as an oarsman, implies much more than this mere art founded on pure science. The fact of your being able to row in a beautiful manner depends on other things than the knowledge of the force of water, or the repeated practice of certain actions in resistance to it. It implies the practice of those actions under a resolved discipline of the body, involving regulation of the passions. It signifies submission to the authority, and amicable concurrence with the humours, of other persons; and so far as it is beautifully done at last, absolutely signifies therefore a moral and intellectual rightness, to the necessary extent influencing the character honourably and graciously. This is the sophia, or wit, of what is most honourable, 
which is concerned in rowing, without which it must become no rowing, or the reverse of rowing.

13. Let us next take example in an art which perhaps you will think (though I hope not) much inferior to rowing, but which is in reality a much higher art-dancing. I have just told you ( $(\mathrm{II})$ how to test the rank of artsnamely, by their corruptibility, as you judge of the fineness of organic substance. The moria,* or folly, of rowing, is only ridiculous, but the moria, or folly, of dancing, is much worse than ridiculous; and, therefore, you may know that its sophia, or wisdom, will be much more beautiful than the wisdom of rowing. Suppose, for instance, a minuet danced by two lovers, both highly bred, both of noble character, and very much in love with each other. You would see, in that, an art of the most highly finished kind, under the government of a sophia which dealt with the strongest passions, and most exquisite perceptions of beauty, possible to humanity.

* If the English reader will pronounce the o in this word as in fold, and in sophia as in sop, but accenting the o, not the $\mathrm{i}$, I need not any more disturb my pages with Greek types. 
14. For example of the contrary of these, in the same art, I cannot give you one more definite than that which I saw at, I think, the Gaiety Theatre-but it might have been at any London theatre now,-two years ago.

The supposed scene of the dance was Hell, which was painted in the background with its flames. The dancers were supposed to be demons, and wore black masks, with red tinsel for fiery eyes; the same red light was represented as coming out of their ears also. They began their dance by ascending through the stage on spring trap-doors, which threw them at once ten feet into the air ; and its performance consisted in the expression of every kind of evil passion, in frantic excess.

15. You will not, I imagine, be at a loss to understand the sense in which the words sophia and moria are to be rightly used of these two methods of the same art. But those of you who are in the habit of accurate thinking will at once perceive that I have introduced a new element into my subject by taking an instance in a higher art. The folly of rowing consisted mainly in not being able to row ; but this folly of dancing does not consist in not being able 
to dance, but in dancing well with evil purpose ; and the better the dancing, the worse the result.

And now I am afraid I must tease you by asking your attention to what you may at first think a vain nicety in analysis, but the nicety is here essential, and I hope throughout this course of Lectures, not to be so troublesome to you again.

16. The mere negation of the power of artthe zero of it-you say, in rowing, is ridiculous. It is, of course, not less ridiculous in dancing. But what do you mean by ridiculous? You mean contemptible, so as to provoke laughter. The contempt, in either case, is slight, in ordinary society; because, though a man may neither know how to row, or dance, he may know many other things. But suppose he lived where he could not know many other things? By a stormy sea-coast, where there could be no fresco-painting, in a poor country, where could be none of the fine arts connected with wealth, and in a simple, and primitive society, not yet reached by refinements of literature; but where good rowing was necessary for the support of life, and good dancing, one of the most vivid aids to domestic pleasure. You wou'd then say that 
inability to row, or to dance, was far worse than ridiculous; that it marked a man for a goodfor-nothing fellow, to be regarded with indignation, as well as contempt.

Now, remember, the inertia or zero of art always involves this kind of crime, or at least, pitiableness. The want of opportunity of learning takes away the moral guilt of artlessness; but the want of opportunity of learning such arts as are becoming in given circumstances, may indeed be no crime in an individual, but cannot be alleged in its defence by a nation. National ignorance of decent art is always criminal, unless in earliest conditions of society ; and then it is brutal.

I7. To that extent, therefore, culpably or otherwise, a kind of moria, or folly, is always indicated by the zero of art-power. But the true folly, or assuredly culpable folly, is in the exertion of our art power in an evil direction. And here we need the finesse of distinction, which I am afraid will be provoking to you. Observe, first, and simply, that the possession of any art-power at all implies a sophia of some kind. These demon dancers, of whom I have just spoken, were earning their bread by severe 
and honest labour. The skill they possessed could not have been acquired but by great patience and resolute self-denial; and the very power with which they were able to express, with precision, states of evil passion, indicated that they had been brought up in a society which, in some measure, knew evil from good, and which had, therefore, some measure of good in the midst of it. Nay, the farther probability is, that if you inquired into the life of these men, you would find that this demon dance had been invented by some one of them with a great imaginative power, and was performed by them not at all in preference of evil, but to meet the demand of a public whose admiration was capable of being excited only by violence of gesture, and vice of emotion.

I 8. In all cases, therefore, observe, where the opportunity of learning has been given; the existence of the art-power indicates sophia and its absence indicates moria. That great fact I endeavoured to express to you, two years since, in my third introductory Lecture. In the present course I have to show you the action of the final, or higher sophia, which directs the skill of art to the best purposes; and of the final, or lower 
moria, which misdirects them to the worst. And the two points I shall endeavour to bring before you throughout will be these:-First, that the object of University teaching is to form your conceptions; - not to acquaint you with arts, nor sciences. It is to give you a notion of what is meant by smith's work, for instance;-but not to make you blacksmiths. It is to give you a notion of what is meant by medicine, but not to make you physicians. The proper academy for blacksmiths is a blacksmith's forge ; the proper academy for physicians is an hospital. Here you are to be taken away from the forge, out of the hospital, out of all special and limited labour and thought, into the 'Universitas' of labour and thought, that you may in peace, in leisure, in calm of disinterested contemplation, be enabled to conceive rightly the laws of nature, and the destinies of Man.

I9. Then the second thing I have to show you is that over these three kingdoms of imagination, art, and science, there reigns a virtue or faculty, which from all time, and by all great people, has been recognised as the appointed ruler and guide of every method of labour, or passion of soul; and the most glorious recompense 
of the toil, and crown of the ambition of man. "She is more precious than rubies, and all the things thou canst desire are not to be compared unto her. Lay fast hold upon her ; let her not go ; keep her, for she is thy life."

Are not these, and the innumerable words like to these, which you remember as I read them, strange words, if Aristotle's statement respecting wisdom be true; that it never contemplates anything that can make men happy,

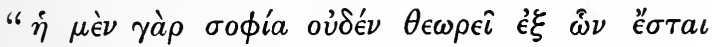
$\epsilon \dot{\delta} \delta a i \mu \omega \nu$ à $\nu \theta \rho \omega \pi{ }^{\prime}$ " ?

When we next meet, therefore, I purpose to examine what it is which wisdom, by preference, contemplates; what choice she makes among the thoughts and sciences open to her, and to what purpose she employs whatever science she may possess.

And I will briefly tell you, beforehand, that the result of the inquiry will be, that instead of regarding none of the sources of happiness, she regards nothing else; that she measures all worthiness by pure felicity; that we are permitted to conceive her as the cause even of gladness to God-" I was daily His delight, rejoicing always before Him,"-and that we are 
commanded to know her as queen of the populous world, "rejoicing in the habitable parts of the Earth, and whose delights are with the sons of Men." 


\section{LECTURE II. \\ OF WISDOM AND FOLLY IN SCIENCE.}

Ioth February, I872.

20. In my last lecture I asserted the positive and negative powers of literature, art, and science; and endeavoured to show you some of the relations of wise art to foolish art. Today we are to examine the nature of these positive and negative powers in science; it being the object of every true school to teach the positive or constructive power, and by all means to discourage, reprove, and extinguish the negative power.

It is very possible that you may not often have thought of, or clearly defined to yourselves, this destructive or deadly character of some elements of science. You may indeed have recognized with Pope that a little knowledge was dangerous, and you have therefore striven 
to drink deep; you may have recognized with Bacon, that knowledge might partially become venomous; and you may have sought, in modesty and sincerity, antidote to the inflating poison. But that there is a ruling spirit or ooфia, under whose authority you are placed, to determine for you, first the choice, and then the use of all knowledge whatsoever; and that if you do not appeal to that ruler, much more if you disobey her, all science becomes to you ruinous in proportion to its accumulation, and as a net to your soul, fatal in proportion to the fineness of its thread,-this, I imagine, few of you, in the zeal of learning, have suspected, and fewer still have pressed their suspicion so far as to recognize or believe.

21. You must have nearly all heard of, many must have seen, the singular paintings; some also may have read the poems, of William Blake. The impression that his drawings once made is fast, and justly, fading away, though they are not without noble merit. But his poems have much more than merit ; they are written with absolute sincerity, with infinite tenderness, and, though in the manner of them diseased and wild, are in verity the words of a great and wise mind, 
disturbed, but not deceived, by its sickness; nay, partly exalted by it, and sometimes giving forth in fiery aphorism some of the most precious words of existing literature. One of these passages I will ask you to remember; it will often be serviceable to you-

"Doth the Eagle know what is in the pit, Or wilt thou go ask the Mole?"

It would be impossible to express to you in briefer terms the great truth that there is a different kind of knowledge good for every different creature, and that the glory of the higher creatures is in ignorance of what is known to the lower.

22. And, above all, this is true of man ; for every other creature is compelled by its instinct to learn its own appointed lesson, and must centralize its perception in its own being. But man has the choice of stooping in science beneath himself, and striving in science beyond himself; and the "Know thyself" is, for him, not a law to which he must in peace submit; but a precept which of all others is the most painful to understand, and the most difficult to fulfil. Most painful to understand, and humiliating; 
and this alike, whether it be held to refer to the knowledge beneath us, oi above. For, singularly enough, men are always most conceited of the meanest science:-

"Doth the Eagle know what is in the pit, Or wilt thou go ask the Mol ? ?"

It is just those who grope with the mole, and cling with the bat, who are vainest of their sight and of their wings.

23. "Know thyself;" but can it indeed be sophia,_can it be the noble wisdom, which thus speaks to science? Is not this rather, you will ask, the voice of the lower virtue of prudence, concerning itself with right conduct, whether for the interests of this world or of the future? Does not sophia regard all that is above and greater than man; and by so much as we are forbidden to bury ourselves in the mole's earthheap, by so much also, are we not urged to raise ourselves towards the stars ?

Indeed, it would at first seem so; nay, in the passage of the Ethics, which I proposed to you to-day for question, you are distinctly told so. There are, it is said, many different kinds of phronesis, by which every animal recognizes 
what is for its own good: and man, like any other creature, has his own separate phronesis telling him what he is to seek, and to do, for the $\mathrm{pl}$ aservation of his life: but above all these forms of prudence, the Greek sage tells you, is the sophia of which the objects are unchangeable and eternal, the methods consistent, and the conclusions universal : and this wisdom has no regard whatever to the things in which the happiness of man consists, but acquaints itself only with the things that are most honourable; so that "we call Anaxagoras and Thales, and such others, wise indeed, but not prudent, in that they know nothing of what is for their own advantage, but know surpassing things, marvellous things, difficult things, and divine things."

24. Now here is a question which evidently touches us closely. We profess at this day to be an especially prudent nation;- to regard only the things which are for our own advantage; to leave to other races the knowledge of surpassing things, marvellous things, divine things, or beautiful things ; and in our exceeding prudence we are, at this moment, refusing the purchase of, perhaps, the most interesting picture by Raphael in the world, and, certainly, 
one of the most beautiful works ever produced by the art-wisdom of man, for five-and-twenty thousand pounds, while we are debating whether we shall not pay three hundred millions to the Americans, as a fine for selling a small frigate to Captain Semmes. Let me reduce these sums from thousands of pounds, to single pounds; you will then see the facts more clearly; (there is not one person in a million who knows what a "million" means; and that is one reason the nation is always ready to let its ministers spend a million or two in cannon, if they can show they have saved twopence-halfpenny in tape). These are the facts then, stating pounds for thousands of pounds; you are offered a Nativity, by Raphael, for five-and-twenty pounds, and cannot afford it; but it is thought you may be bullied into paying three hundred thousand pounds, for having sold a ship to Captain Semmes. I do not say you will pay it. Still your present position is one of deprecation and humility, and that is the kind of result which you bring about by acting with what you call "practical common sense," instead of Divine wisdom.

25. Perhaps you think I am losing Aristotle's notion of common sense, by confusing it with 
our vulgar English one; and that selling ships or ammunition to people whom we have not courage to fight either for or against, would not by Aristotle have been held a phronetic, or prudent proceeding. $\mathrm{Be}$ it so; let us be certain then, if we can, what Aristotle does mean. Take the instance I gave you in the last lecture, of the various modes of feeling in which a master of literature, of science, and of art, would severally regard the storm round the temples of Pæstum.

The man of science, we said, thought of the origin of the electricity; the artist of its light in the clouds, and the scholar, of its relation to the power of Zeus and Poseidon. There you have Episteme; Techne; and Nous; well, now what does Phronesis do?

Phronesis puts up his umbrella, and goes home as fast as he can. Aristotle's Phronesis at least does; having no regard for marvellous things. But are you sure that Aristotle's Phronesis is indeed the right sort of Phronesis? May there not be a commonsense, as well as an art, and a science, under the command of sophia? Let us take an instance of a more subtle kind. 
26. Suppose that two young ladies, (I assume in my present lectures, that none are present, and that we may say among ourselves what we like; and we do like, do we not, to suppose that young ladies excel us only in prudence, and not in wisdom ?) let us suppose that two young ladies go to the observatory on a winter night, and that one is so anxious to look at the stars that she does not care whether she gives herself cold, or not; but the other is prudent, and takes care, and looks at the stars only as long as she can without catching cold. In Aristotle's mind the first young lady would properly deserve the name of Sophia, and the other that of Prudence. But in order to judge them fairly, we must assume that they are acting under exactly the same conditions. Assume that they both equally desire to look at the stars; then, the fact that one of them stops when it would be dangerous to look longer, does not show that she is less wise,-less interested, that is to say, in surpassing and marvellous things;-but it shows that she has more self-command, and is able therefore to remember what the other does not think of. She is equally wise, and more sensible. But suppose 
that the two girls are originally different in disposition; and that the one, having much more imagination than the other, is more interested in these surpassing and marvellous things ; so that the self-command, which is enough to stop the other, who cares little for the stars, is not enough to stop her who cares much for them;-you would say, then, that, both the girls being equally sensible, the one that caught cold was the wisest.

27. Let us make a farther supposition. Returning to our first condition, that both the girls desire equally to look at the stars; let us put it now that both have equal self-command, and would therefore, supposing no other motives were in their minds, together go on star-gazing, or together stop star-gazing; but that one of them has greater consideration for her friends than the other, and though she would not mind catching cold for her own part, would mind it much for fear of giving her mother trouble. She will leave the stars first, therefore; but should we be right now in saying that she was only more sensible than her companion, and not more wise? This respect for the feelings of others, this understanding of her duty 
towards others, is a much higher thing than the love of stars. It is an imaginative knowledge, not of balls of fire or differences of space, but of the feelings of living creatures, and of the forces of duty by which they justly move. This is a knowledge, or perception, therefore, of a thing more surpassing and marvellous than the stars themselves, and the grasp of it is reached by a higher sophia.

28. Will you have patience with me for one supposition more? We may assume the attraction of the spectacle of the heavens to be equal in degree, and yet, in the minds of the two girls, it may be entirely different in kind. Supposing the one versed somewhat in abstract Science, and more or less acquainted with the laws by which what she now sees may be explained; she will probably take interest chiefly in questions of distance and magnitude, in varieties of orbit, and proportions of light. Supposing the other not versed in any science of this kind, but acquainted with the traditions attached by the religion of dead nations to the figures they discerned in the sky: she will care little for arithmetical or geometrical matters, but will probably receive a much deeper emotion, from 
witnessing in clearness what has been the amazement of so many eyes long closed; and recognizing the same lights, through the same darkness, with innocent shepherds and husbandmen, who knew only the risings and settings of the immeasurable vault, as its lights shone on their own fields or mountains; yet saw true miracle in them, thankful that none but the Supreme Ruler could bind the sweet influences of Pleiades, or loose the bands of Orion. I need not surely tell you, that in this exertion of the intellect and the heart, there would be a far nobler sophia than any concerned with the analysis of matter, or the measurement of space.

29. I will not weary you longer with questions, but simply tell you, what you will find ultimately to be true, that sophia is the form of thought, which makes common sense unselfish, -knowledge unselfish, - art unselfish, - and wit and imagination unselfish. Of all these, by themselves, it is true that they are partly venomous; that, as knowledge puffeth up, so does prudence-so does art-so does wit; but, added to all these, wisdom, or (you may read it as an equivalent word), added to all these-charity, edifieth. 
30. Note the word; builds forward, or builds up, and builds securely because on modest and measured foundation, wide, though low, and in the natural and living rock.

Sophia is the faculty which recognizes in all things their bearing upon life, in the entire sum of life that we know, bestial and human; but, which, understanding the appointed objects of that life, concentrates its interest and its power on Humanity, as opposed on the one side to the Animalism which it must rule, and distinguished on the other side from the Divinity which rules it, and which it cannot imagine.

It is as little the part of a wise man to reflect much on the nature of beings above him, as of beings beneath him. It is immodest to suppose that he can conceive the one, and degrading to suppose that he should be busied with the other. To recognize his everlasting inferiority, and his everlasting greatness; to know himself, and his place; to be content to submit to God without understanding $\mathrm{Him}$; and to rule the lower creation with sympathy and kindness, yet neither sharing the passion of the wild beast, nor imitating the science of the Insect; -this you will find is to be modest towards 
God, gentle to His creatures, and wise for himself.

3I. I think you will now be able to fasten in your minds, first the idea of unselfishness, and secondly, that of modesty, as component elements of sophia; and having obtained thus much, we will at once make use of our gain, by rendering more clear one or two points respecting its action on art, that we may then see more surely its obscurer function in science.

It is absolutely unselfish, we say, not in the sense of being without desire, or effort to gratify that desire; on the contrary, it longs intensely to see, or know the things it is rightly interested in. But it is not interested specially in itself. In the degree of his wisdom, an artist is unconcerned about his work as his own ; - concerned about it only in the degree in which he would be, if it were another man'srecognizing its precise value, or no value, from that outer standpoint. I do not think, unless you examine your minds very attentively, that you can have any conception of the difficulty of doing this. Absolutely to do it is impossible, for we are all intended by nature to be a little unwise, and to derive more pleasure, 
therefore, from our own success than that of others. But the intense degree of the difference is usually unmeasured by us. In preparing the drawings for you to use as copies in these schools, my assistant and I are often sitting beside each other; and he is at work, usually, on the more important drawing of the two. I so far recognize that greater importance, when it exists, that if I had the power of determining which of us should succeed, and which fail, I should be wise enough to choose his success rather than my own. But the actual effect on my own mind, and comfort, is very different in the two cases. If he fails, I am sorry, but not mortified ; - on the contrary, perhaps a little pleased. I tell him, indulgently, ' he will do better another time,' and go down with great contentment to my lunch. But, if $I$ fail, though I would rather, for the sake of the two drawings, have had it so, the effect on my temper is very different. I say, philosophically, that it was better so-but I can't eat any lunch.

32. Now, just imagine what this inherently selfish passion-unconquerable as you will find it by the most deliberate and maintained efforts 
- fancy what it becomes, when instead of striving to subdue, we take every means in our power to increase and encourage it ; and when all the circumstances around us concur in the deadly cultivation. In all base schools of Art, the craftsman is dependent for his bread on originality; that is to say, on finding in himself some fragment of isolated faculty, by which his work may be recognized as distinct from that of other men. We are ready enough to take delight in our little doings, without any such stimulus;-what must be the effect of the popular applause which continually suggests that the little thing we can separately do is as excellent as it is singular! and what the effect of the bribe, held out to us through the whole of life, to produce-it being also at our peril not to produce-something different from the work of our neighbours? In all great schools of art these conditions are exactly reversed. An artist is praised in these, not for what is different in him from others, nor for solitary performance of singular work; but only for doing most strongly what all are endeavouring; and for contributing, in the measure of his strength, to some great achievement, to be 
completed by the unity of multitudes, and the sequence of ages.

33. And now, passing from art to science, the unselfishness of sophia is shown by the value it therein attaches to every part of knowledge, new or old, in proportion to its real utility to mankind, or largeness of range in creation. The selfishness which renders sophia impossible, and enlarges the elastic and vaporous kingdom of folly, is shown by our caring for knowledge only so far as we have been concerned in its discovery, or are ourselves skilled and admired in its communication. If there is an art which "puffeth up," even when we are surrounded by magnificence of achievement of past ages, confessedly not by us to be rivalled, how much more must there be a science which puffeth up, when, by the very condition of science, it must be an advance on the attainments of former time, and however slight, or however slow, is still always as the leaf of a pleasant spring compared to the dried branches of years gone by? And, for the double calamity of the age in which we live, it has chanced that the demand of the vulgar and the dull for originality in Art, is associated with the demand 
of a sensual economy for originality in science; and the praise which is too readily given always to discoveries that are new, is enhanced by the reward which rapidity of communication now ensures to discoveries that are profitable. What marvel if future time shall reproach us with having destroyed the labours, and betrayed the knowledge of the greatest nations and the wisest men, while we amused ourselves with fantasy in art, and with theory in science: happy, if the one was idle without being vicious, and the other mistaken without being mischievous. Nay, truth, and success, are often to us more deadly than error. Perhaps no progress more triumphant has been made in any science than that of Chemistry; but the practical fact which will remain for the contemplation of the future, is that we have lost the art of painting on glass, and invented gun-cotton and nitroglycerine. "Can you imagine," the future will say, "those English fools of the nineteenth century, who went about putting up memorials of themselves in glass which they could not paint, and blowing their women and children to pieces with cartridges they would not fight with?" 
34. You may well think, gentlemen, that I am unjust and prejudiced in such sayings;-you may imagine that when all our mischievous inventions have done their worst, and the wars they provoked by cowardice have been forgotten in dishonour, our great investigators will be remembered, as men who laid first the foundations of fruitful knowledge, and vindicated the majesty of inviolable law. No, gentlemen; it will not be so. In a little while, the discoveries of which we are now so proud will be familiar to all. The marvel of the future will not be that we should have discerned them, but that our predecessors were blind to them. We may be envied, but shall not be praised, for having been allowed first to perceive and proclaim what could be concealed no longer. But the misuse we made of our discoveries will be remembered against us, in eternal history ; our ingenuity in the vindication, or the denial, of species, will be disregarded in the face of the fact that we destroyed, in civilized Europe, every rare bird and secluded flower; our chemistry of agriculture will be taunted with the memories of irremediable famine; and our mechanical contrivance will only make the age of the 
mitrailleuse more abhorred than that of the guillotine.

35. Yes, believe me, in spite of our political liberality, and poetical philanthropy ; in spite of our almshouses, hospitals, and Sunday-schools; in spite of our missionary endeavours to preach abroad what we cannot get believed at home; and in spite of our wars against slavery, indemnified by the presentation of ingenious bills, - we shall be remembered in history as the most cruel, and therefore the most unwise, generation of men that ever yet troubled the earth :- the most cruel in proportion to their sensibility,-the most unwise in proportion to their science. No people, understanding pain, ever inflicted so much: no people, understanding facts, ever acted on them so little. You execrate the name of Eccelin of Padua, because he slew two thousand innocent persons to maintain his power; and Dante cries out against Pisa that she should be sunk in the sea, because, in revenge for treachery, she put to death, by the slow pangs of starvation, not the traitor only, but his children. But we men of London, we of the modern Pisa, slew, a little while since, five hundred thousand men instead 
of two thousand-(I speak in official terms, and know my numbers) - these we slew, all guiltless; and these we slew, not for defence, nor for revenge, but most literally in cold blood; and these we slew, fathers and children together, by slow starvation-simply because, while we contentedly kill our own children in competition for places in the Civil Service, we never ask, when once they have got the places, whether the Civil Service is done.

36. That was our missionary work in Orissa, some three or four years ago;-our Christian miracle of the five loaves, assisted as we are in its performance, by steam-engines for the threshing of the corn, and by railroads for carrying it, and by proposals from English noblemen to cut down all the trees in England, for better growing it. That, I repeat, is what we did, a year or two ago; what are we doing now? Have any of you chanced to hear of the famine in Persia? Here, with due science, we arrange the roses in our botanic garden, thoughtless of the country of the rose. With due art of horticulture, we prepare for our harvest of peaches;-it might perhaps seriously alarm us to hear, next autumn, of a coming 
famine of peaches. But the famine of all things, in the country of the peach-do you know of it, care for it:-quaint famine that it is, in the fruitfullest, fairest, richest of the estates of earth; from which the Magi brought their treasures to the feet of Christ?

How much of your time, scientific faculty, popular literature, has been given, since this year began, to ascertain what England can do for the great countries under her command, or for the nations that look to her for help; and how much to discuss the chances of a single impostor's getting a few thousands a year ?

Gentlemen, if your literature, popular and other; or your art, popular and other; or your science, popular and other, is to be eagle-eyed, remember that question I to-day solemnly put to you-will you hawk at game or carrion? Shall it be only said of the thoughts of the heart of England-"Wheresoever the carcase is, thither shall the eagles be gathered together"? 


\section{LECTURE III.}

THE RELATION OF WISE ART TO WISE SCIENCE.

"The morrow after St. Valentine's," I 872.

37. Our task to-day is to examine the relation between art and science, each governed by sophia, and becoming capable, therefore, of consistent and definable relation to each other. Between foolish art and foolish science, there may indeed be all manner of reciprocal mischievous influence; but between wise art and wise science there is essential relation, for each other's help and dignity.

You observe, I hope, that I always use the term 'science,' merely as the equivalent of 'knowledge.' I take the Latin word, rather than the English, to mark that it is knowledge of constant things, not merely of passing events : but you had better lose even that distinction, and receive the word "scientia" as merely the equivalent of our English "knowledge," than 
III. RELATION OF WISE ART TO WISE SCIENCE. 47

fall into the opposite error of supposing that science means systematization or discovery. It is not the arrangement of new systems, nor the discovery of new facts, which constitutes a man of science; but the submission to an eternal system; and the proper grasp of facts already known.

38. And, at first, to-day, I use the word "art" only of that in which it is my special office to instruct you ; graphic imitation ; or, as it is commonly called, Fine art. Of course, the arts of construction, - building, carpentering, and the like, are directly dependent on many sciences, but in a manner which needs no discussion, so that we may put that part of the business out of our way. I mean by art, today, only imitative art ; and by science, to-day, not the knowledge of general laws, but of existent facts. I do not mean by science, for instance, the knowledge that triangles with equal bases and between parallels, are equal, but the knowledge that the stars in Cassiopeia are in the form of a W.

Now, accepting the terms 'science' and 'art' under these limitations, wise art is only the reflex or shadow of wise science. Whatever it 
is really desirable and honourable to know, it is also desirable and honourable to know as completely and as long as possible; therefore, to present, or re-present, in the most constant manner ; and to bring again and again, not only within the thoughts, but before the eyes; describing it, not with vague words, but distinct lines, and true colours, so as to approach always as nearly as may be to the likeness of the thing itself.

39. Can anything be more simple, more evidently or indisputably natural and right, than such connection of the two powers? That you should desire to know what you ought; what is worthy of your nature, and helpful to your life: to know that;-nothing less,-nothing more ; and to keep record and definition of such knowledge near you, in the most vivid and explanatory form?

Nothing, surely, can be more simple than this; yet the sum of art judgment and of art practice is in this. You are to recognize, or know, beautiful and noble things-notable, notabilia, or nobilia; and then you are to give the best possible account of them you can, either for the sake of others, or for the sake of 
11I. RELATION OF WISE ART TO WISE SCIENCE. 49

your own forgetful or apathetic self, in the future.

Now as I gave you and asked you to remember without failing, an aphorism which embraced the law of wise knowledge, so, to-day, I will ask you to remember, without fail, one, which absolutely defines the relation of wise art to it. I have, already, quoted our to-day's aphorism to you, at the end of my fourth lecture on sculpture. Read the few sentences at the end of that lecture now, down to

"THE BEST, IN THIS KIND, ARE BUT SHADOWS."

That is Shakspeare's judgment of his own art. And by strange coincidence, he has put the words into the mouth of the hero whose shadow, or semblance in marble, is admittedly the most ideal and heroic we possess, of man; yet, I need not ask you, whether of the two, if it were granted you to see the statue by Phidias, or the hero Theseus himself, you would choose rather to see the carved stone, or the living King. Do you recollect how Shakspeare's Theseus concludes his sentence, spoken of the poor tradesmen's kindly offered art, in the "Midsuminer Night's Dream "? 
"The best in this kind are but shadows : and the worst are no worse, if imagination amend them."

It will not burden your mèmories painfully, I hope, though it may not advance you materially in the class list, if you will learn this entire sentence by heart, being, as it is, a faultless and complete epitome of the laws of mimetic art.

40. "But Shadows!" Make them as beautiful as you can; use them only to enable you to remember and love what they are cast by. If ever you prefer the skill of them to the simplicity of the truth, or the pleasure of them to the power of the truth, you have fallen into that vice of folly, (whether you call her какía or $\mu \omega$ ía, $)$ which concludes the subtle description of her given by Prodicus, that she might be seen

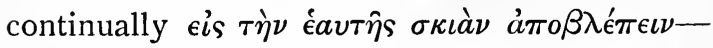
to look with love, and exclusive wonder, at her own shadow.

4I. There is nothing that I tell you with more eager desire that you should believe-nothing with wider ground in my experience for requiring you to believe, than this, that you never will love art well, till you love what she mirrors better. 
III. RELATION OF WISE ART TO WISE SCIENCE. 5 I

It is the widest, as the clearest experience I have to give you; for the beginning of all my own right art work in life, (and it may not be unprofitable that I should tell you this,) depended not on my love of art, but of mountains and sea. All boys with any good in them are fond of boats, and of course I liked the mountains best when they had lakes at the bottom; and I used to walk always in the middle of the loosest gravel I could find in the roads of the midland counties, that I might hear, as I trod on it, something like the sound of the pebbles on sea-beach. No chance occurred for some time to develop what gift of drawing I had; but I would pass entire days in rambling on the Cumberland hill-sides, or staring at the lines of surf on a low sand; and when I was taken annually to the Water-colour Exhibition, I used to get hold of a catalogue before-hand, mark all the Robsons, which I knew would be of purple mountains, and all the Copley Fieldings, which I knew would be of lakes or sea; and then go deliberately round the room to these, for the sake, observe, not of the pictures, in any wise, but only of the things painted.

And through the whole of following life, 
whatever power of judgment I have obtained, in art, which I am now confident and happy in using, or communicating, has depended on my steady habit of always looking for the subject principally, and for the art, only as the means of expressing it.

42. At first, as in youth one is almost sure to be, I was led too far by my certainty of the rightness of this principle : and provoked into its exclusive assertion by the pertinacity with which other writers denied it: so that, in the first volume of "Modern Painters," several passages occurred setting the subject or motive of the picture so much above the mode of its expression, that some of my more feebly gifted disciples supposed they were fulfilling my wishes by choosing exactly the subjects for painting which they were least able to paint. But the principle itself, I maintain, now in advanced life, with more reverence and firmness than in earliest youth: and though I believe that among the teachers who have opposed its assertion, there are few who enjoy the mere artifices of composition or dexterities of handling so much as I, the time which I have given to the investigation of these has only farther 
III. RELATION OF WISE ART TO WISE SCIENCE. 53

assured me that the pictures were noblest which compelled me to forget them.

43. Now, therefore, you see that on this simple theory, you have only to ask what will be the subjects of wise science ; these also, will be, so far as they can be imitatively or suggestively represented, the subjects of wise art : and the wisdom of both the science and art will be recognized by their being lofty in their scope, but simple in their language; clear in fancy, but clearer in interpretation ; severe in discernment, but delightful in display.

44. For example's sake, since we have just been listening to Shakspeare as a teacher of science and art, we will now examine him as a subject of science and art.

Suppose we have the existence and essence of Shakspeare to investigate, and give permanent account of ; we shall see that, as the scope and bearing of the science become nobler, art becomes more helpful to it; and at last, in its highest range, even necessary to it; but still only as its minister.

We examine Shakspeare, first, with the science of chemistry, which informs us that Shakspeare consists of about seventy-five parts 
in the hundred of water, some twelve or fifteen of nitrogen, and the rest, lime, phosphorus, and essential earthy salts.

We next examine him by the science of anatomy, which tells us (with other such matters,) that Shakspeare has seven cervical, twelve dorsal, and five lumbar vertebræ; that his fore arm has a wide sphere of rotation; and that he differs from other animals of the ape species by being more delicately prehensile in the fingers, and less perfectly prehensile in the toes.

We next approach Shakspeare with the science of natural history, which tells us the colour of his eyes and hair, his habits of life, his temper, and his predilection for poaching.

There ends, as far as this subject is concerned, our possible science of substantial things. Then we take up our science of ideal things : first of passion, then of imagination; and we are told by these that Shakspeare is capable of certain emotions, and of mastering or commanding them in certain modes. Finally, we take up our science of theology, and ascertain that he is in relation, or in supposed relation, with such and such a Being, greater than himself. 
III. RELATION OF WISE ART TO WISE SCIENCE. 55

45. Now, in all these successive stages of scientific description, we find art become powerful as an aid or record, in proportion to the importance of the inquiry. For chemistry, she can do scarcely anything: merely keep note of a colour, or of the form of a crystal. For anatomy, she can do somewhat more; and for natural history, almost all things: while in recording passion, and affectionate intellect, she walks hand in hand with the highest science; and to theology, can give nobler aid even than verbal expression of literature.

46. And in considering this power of hers, remember that the theology of art has only of late been thought deserving of attention : Lord Lindsay, some thirty years ago, was the first to recognize its importance; and when I entered upon the study of the schools of Tuscany in I 845, his "Christian Mythology" was the only guide I could trust. Even as late as I860, I had to vindicate the true position, in Christian science, of Luini, the despised pupil of Leonardo. But only assuming, what with general assent I might assume, that Raphael's dispute of the Sacrament-(or by its less frequently given, but true name-Raphael's Theologia,) is 
the most perfect effort yet made by art to illustrate divine science, I am prepared hereafter to show you that the most finished efforts of theologic literature, as compared with that piece of pictorial interpretation, have expressed less fully the condition of wise religious thought; and have been warped more dangerously into unwise religious speculation.

47. Upon these higher fields of inquiry we are not yet to enter. I shall endeavour for some time only to show you the function of modest art, as the handmaid of natural science; and the exponent, first of the beauty of the creatures subject to your own human life; and then of the history of that life in past time; of which one chief source of illustration is to be found in the most brilliant, and in its power on character, hitherto the most practically effective of the arts - Heraldry.

In natural history, I at first intended to begin with the lower types of life; but as the enlarged schools now give me the means of extending the use of our examples, we will at once, for the sake of more general service, take up ornithology, of the uses of which, in general culture,

I have one or two grave words to say. 
III. RELATION OF WISE ART TO WISE SCIENCE. 57

48. Perhaps you thought that in the beginning of my lecture to-day I too summarily dismissed the arts of construction and action. But it was not in disrespect to them; and I must indeed ask you carefully to note one or two points respecting the arts of which an example is set us by birds;-building, and singing.

The other day, as I was calling on the ornithologist whose collection of birds is, I suppose, altogether unrivalled in Europe,-(at once a monument of unwearied love of science, and an example, in its treatment, of the most delicate and patient art)-Mr. Gould-he showed me the nest of a common English bird; a nest which, notwithstanding his knowledge of the dexterous building of birds in all the world, was not without interest even to him, and was altogether amazing and delightful to me. It was a bullfinch's nest, which had been set in the fork of a sapling tree, where it needed an extended foundation. And the bird had built this first story of her nest with withered stalks of clematis blossom; and with nothing else. These twigs it had interwoven lightly, leaving the branched heads all at the outside, producing an intricate Gothic boss of extreme grace 
and quaintness, apparently arranged both with triumphant pleasure in the art of basket-making, and with definite purpose of obtaining ornamental form.

49. I fear there is no occasion to tell you that the bird had no purpose of the kind. I say that I fear this, because I would much rather have to undeceive you in attributing too much intellect to the lower animals, than too little. But I suppose the only error which, in the present condition of natural history, you are likely to fall into, is that of supposing that a bullfinch is merely a mechanical arrangement of nervous fibre, covered with feathers by a chronic cutaneous eruption; and impelled by a galvanic stimulus to the collection of clematis.

50. You would be in much greater, as well as in a more shameful, error, in supposing this, than if you attributed to the bullfinch the most deliberate rivalship with Mr. Street's prettiest Gothic designs. The bird has exactly the degree of emotion, the extent of science, and the command of art, which are necessary for its happiness; it had felt the clematis twigs to be lighter and tougher than any others within its reach, and probably found the forked branches 
of them convenient for reticulation. It had naturally placed these outside, because it wanted a smooth surface for the bottom of its nest; and the beauty of the result was much more dependent on the blossoms than the bird.

5 I. Nevertheless, I am sure that if you had seen the nest,-much more, if you had stood beside the architect at work upon it, - you would have greatly desired to express your admiration to her; and that if Wordsworth, or any other simple and kindly person, could even wish, for a little flower's sake,

"That to this mountain daisy's self were known The beauty of its star-shaped shadow, thrown On the smooth surface of this naked stone,"

much more you would have yearned to inform the bright little nest-builder of your sympathy ; and to explain to her, on art principles, what a pretty thing she was making.

52. Does it never occur to you, then, that to some of the best and wisest artists among ourselves, it may not be always possible to explain what pretty things they are making; and that, perhaps, the very perfection of their art is in their knowing so little about it ?

Whether it has occurred to you or not, I 
assure you that it is so. The greatest artists, indeed, will condescend, occasionally, to be scientific;-will labour, somewhat systematically, about what they are doing, as vulgar persons do ; and are privileged, also, to enjoy what they have made more than birds do ; yet seldom, observe you, as being beautiful, but very much in the sort of feeling which we may fancy the bullfinch had also,- - that the thing, whether pretty or ugly, could not have been better done; that they could not have made it otherwise, and are thankful it is no worse. And, assuredly, they have nothing like the delight in their own work which it gives to other people.

53. But putting the special simplicities of good artists out of question, let me ask you, in the second place, whether it is not possible that the same sort of simplicity might be desirable in the whole race of mankind; and that we ought all to be doing human work which would appear better done to creatures much above us, than it does to ourselves. Why should not our nests be as interesting things to angels, as bullfinches' nests are to us ?

You will, probably, both smile at, and shrink from, such a supposition, as an insolent one. 
III. RELATION OF WISE ART TO WISE SCIENCE. 6 I

But to my thought, it seems, on the contrary, the only modest one. That we should be able to admire the work of angels seems to me the impertinent idea; not, at all, that they should be able to admire ours.

54. Under existing circumstances, I confess the difficulty. It cannot be imagined that either the back streets of our manufacturing towns, or the designs of our suburban villas, are things which the angels desire to look into: but it seems to me an inevitable logical conclusion that if we are, indeed, the highest of the brute creation, we should, at least, possess as much unconscious art as the lower brutes; and build nests which shall be, for ourselves, entirely convenient; and may, perhaps, in the eyes of superior beings, appear more beautiful than to our own.

55. "Which shall be, for ourselves, entirely convenient." Note the word;-becoming, decorous, harmonious, satisfying. We may not be able to build anything sublime; but, at all events, we should, like other flesh-invested creatures, be able to contrive what was decent, and it should be a human privilege to think that we may be admired in heaven for our contrivance. 
I have some difficulty in proceeding with what I want to say, because I know you must partly think I am jesting with you. I feel indeed some disposition to smile myself; not because I jest, but in the sense of contrast between what, logically, it seems, ought to be; and what we must confess, not jestingly, to be the facts. How great also,-how quaint, the confusion of sentiment in our minds, as to this matter! We continually talk of honouring God with our buildings; and yet, we dare not say, boldly, that, in His sight, we in the least expect to honour ourselves by them! And admitting, though I by no means feel disposed to admit, that here and there we may, at present, be honouring Him by work that is worthy of the nature He gave us, in how many places, think you, are we offending Him by work that is disgraceful to it?

56. Let me return, yet for an instant, to my bird and her nest. If not actually complacent and exultant in her architecture, we may at least imagine that she, and her mate, and the choir they join with, cannot but be complacent and exultant in their song. I gave you, in a former lecture, the skylark as a type of mastership in 
III. RELATION OF WISE ART TO WISE SCIENCE. 63

music; and remembering-some of you, I suppose, are not likely soon to forget,-the saint to whom yesterday was dedicated, let me read to you to-day some of the prettiest English words in which our natural feeling about such song is expressed.

"And anone, as I the day espide, No lenger would I in my bed abids, But unto a wood that was fast by, I went forth alone boldely, And held the way downe by a brook side,

Till I came to a laund of white and green, So faire one had I never in been, The ground was green, ypoudred with daisie, The floures and the greves like hie, All greene and white, was nothing els seene.

There sat I downe among the faire flours, And saw the birds trip out of hir bours, There as they rested hem all the night, They were so joyfull of the dayes light, They began of May for to done honours.

They coud that service all by rote, There was many a lovely note, Some sang loud, as they had plained, And some in other manner voice yfained, And some all out with the full throte.

They proyned hem and made hem right gay, And daunceden and lepten on the spray, And evermore two and two in fere, Right so as they had chosen hem to yere In Feverere, upon saint Valentines day." 
You recollect, perhaps, the dispute that follows between the cuckoo and the nightingale, and the promise which the sweet singer makes to Chaucer for rescuing her.

"And then came the Nightingale to me And said Friend, forsooth I thanke thee That thou hast liked me to rescue, And one avow to Love make I now That all this May, I will thy singer be.

I thanked her, and was right well apaied, Yea, quoth she, and be not thou dismaied, Tho' thou have heard the cuckoo erst than me; For, if I live, it shall amended be, The next May, if I be not affraied."

"If I be not affraied." Would she not put the "if" more timidly now, in making the same promise to any of you, or in asking for the judgment between her and her enemy, which was to be past, do you remember, on this very day of the year, so many years ago, and within eight miles of this very spot?

"And this shall be without any Nay

On the morrow after St. Valentine's day,

Under a maple that is faire and green

Before the chamber window of the Queen

At Woodstoke, upon the greene lawn.

She thanked them, and then her leave took And into an hawthorn by that broke. 
III. RELATION OF WISE ART TO WISE SCIENCE. 65

And there she sate, and sang upon that tree

'Terme of life love hath withheld me'

So loud, that I with that song awoke."

57. "Terme of life love hath withheld me!" Alas, how have we men reversed this song of the nightingale! so that our words must be "Terme of life, hatred hath withheld me."

This, then, was the old English science of the song of birds; and perhaps you are indignant with me for bringing any word of it back to you? You have, I doubt not, your new science of song, as of nest-building: and I am happy to think you could all explain to me, or at least you will be able to do so before you pass your natural science examination, how, by the accurate connection of a larynx with a bill, and by the action of heat, originally derived from the sun, upon the muscular fibre, an undulatory motion is produced in the larynx, and an opening and shutting one in the bill, which is accompanied, necessarily, by a piping sound.

58. I will not dispute your statement; still less do I wish to answer for the absolute truth of Chaucer's. You will find that the complete truth embraces great part of both; and that you may study, at your choice, in any singing 
bird, the action of universal heat on a marvellous mechanism, or of individual life, on a frame capable of exquisite passion. But the point I wish you to consider is the relation to this lower creature's power, of your own human agencies in the production of sound, where you can best unite in its harmony.

59. I had occasion only the other day to wait for half an hour at the bottom of Ludgate Hill. Standing as much out of the way as I could, under the shadow of the railroad bridge, I watched the faces, all eager, many anxious, and some intensely gloomy, of the hurried passers by ; and listened to the ceaseless crashing, whistling, and thundering sounds which mingled with the murmur of their steps and voices. And in the midst of the continuous roar, which differed only from that of the wildest sea in storm by its complexity and its discordance, I was wondering, if the sum of what all these people were doing, or trying to do, in the course of the day, could be made manifest, what it would come to.

6o. The sum of it would be, I suppose, that they had all contrived to live through the day. in that exceedingly unpleasant manner, and that 
III. RELATION OF WISE ART TO WISE SCIENCE. 67 nothing serious had occurred to prevent them from passing the following day likewise. Nay, I knew also that what appeared in their way of life painful to me, might be agreeable to them ; and it chanced, indeed, a little while afterwards, that an active and prosperous man of business, speaking to one of my friends of the disappointment he had felt in a visit to Italy, remarked, especially, that he was not able to endure more than three days at Venice, because there was no noise there.

6r. But, granting the contentment of the inhabitants of London in consistently producing these sounds, how shall we say this vocal and instrumental art of theirs may compare, in the scheme of Nature, with the vocal art of lower animals? We may indeed rank the dangerwhistle of the engines on the bridge as an excruciating human improvement on that of the marmot; and the trampling of feet and grinding of wheels, as the human accentuation of the sounds produced by insects, by the friction of their wings or thighs against their sides : but, even in this comparison, it may cause us some humiliation to note that the cicada and the cricket, when pleased to sing in their vibratory 
manner, have leisure to rest in their delight; and that the flight of the firefly is silent. But how will the sounds we produce compare with the song of birds? This London is the principal nest of men in the world ; and I was standing in the centre of it. In the shops of Fleet Street and Ludgate Hill, on each side of me, I do not doubt I could have bought any quantity of books for children, which by way of giving them religious, as opposed to secular, instruction, informed them that birds praised God in their songs. Now, though, on the one hand, you may be very certain that birds are not machines, on the other hand it is just as certain that they have not the smallest intention of praising God in their songs; and that we cannot prevent the religious education of our children more utterly than by beginning it in lies. But it might be expected of ourselves that we should do so, in the songs we send up from our principal nest ! And although, under the dome at the top of Ludgate Hill, some attempt of the kind may be made every seventh day, by a limited number of persons, we may again reflect, with humiliation, that the birds, for better or worse, sing all, and every day; and I could not but ask myself, with 
III. RELATION OF WISE ART TO WISE SCIENCE. 69

momentarily increasing curiosity, as I endeavoured to trace the emotions and occupations of the persons who passed by me, in the expression of their faces-what would be the effect on them, if any creatures of higher order were suddenly to appear in the midst of them with any such message of peace, and invitation to rejoicing, as they had all been professing to commemorate at Christmas.

62. Perhaps you recollect, in the lectures given on landscape during the spring of this year, my directing your attention to a picture of Mantegna's in the loan exhibition, representing a flight of twelve angels in blue sky, singing that Christmas song. I ought to tell you, however, that one of our English artists of good position dissented from my opinion about the picture; and remarked that in England "we wanted good art, and not funny art." Whereas, to me, it is this vocal and architectural art of Ludgate Hill which appears funny art; and not Mantegna's. But I am compelled to admit that could Mantegna's picture have been realized, the result would, in the eyes of most men, have been funnier still. For suppose that over Ludgate Hill the sky had indeed suddenly become 
blue instead of black; and that a flight of twelve angels, "covered with silver wings, and their feathers with gold," had alighted on the cornice of the railroad bridge, as the doves alight on the cornices of St. Mark's at Venice ; and had invited the eager men of business below, in the centre of a city confessedly the most prosperous in the world, to join them for five minutes in singing the first five verses of such a psalm as the Io3rd-"Bless the Lord, oh my soul, and all that is within me," (the opportunity now being given for the expression of their most hidden feelings) "all that is within me, bless His holy name, and forget not all His benefits." Do you not even thus, in mere suggestion, feel shocked at the thought, and as if my now reading the words were profane? And cannot you fancy that the sensation of the crowd at so violent and strange an interruption of traffic, might be somewhat akin to that which I had occasion in my first lecture on sculpture to remind you of, -the feeling attributed by Goethe to Mephistopheles at the song of the angels: "Discord I hear, and intolerable jingling" ?

63. Nay, farther, if indeed none of the benefits bestowed on, or accomplished by, the great city. 
were to be forgotten, and if search were made, throughout its confines, into the results of its wealth, might not the literal discord in the words themselves be greater than the felt discord in the sound of them ?

I have here in my hand a cutting from a newspaper, which I took with me three years ago, to a meeting in the interest of social science, held in the rooms of the Society of Arts, and under the presidency of the Prime Minister of England. Under the (so called) ' classical' paintings of Barry, representing the philosophy and poetry of the ancients, Mr. Gladstone was in the chair; and in his presence a member of the Society for the Promotion of Social Science propounded and supported the statement, not irrelevant to our present inquiry, that the essential nature of man was that of a beast of prey. Though, at the time, (suddenly called upon by the author of "Tom Brown at Oxford,") I feebly endeavoured to contradict that Socially Scientific person, I do not at present desire to do so. I have given you a creature of prey for comparison of knowledge. "Doth the eagle know what is in the pit ?"- -and in this great nest of ours in London, it would 
be well if to all our children the virtue of the creature of prey were fulfilled, and that, indeed, the stir and tumult of the city were "as the eagle stirreth up her nest and fluttereth over her young." But the slip of paper I had then, and have now, in my hand,* contains information about the state of the nest, inconsistent with such similitude. I am not answerable for the juxtaposition of paragraphs in it. The first is a proposal for the building of a new church in Oxford, at the cost of twenty thousand pounds; the second is the account of the inquest on a woman and her child who were starved to death in the Isle of Dogs. The bodies were found lying, without covering, on a bed made of heaped rags; and there was no furniture in the room but a wooden stool, on which lay a tract entitled "The Goodness of God." The husband, who had been out of work for six months, went mad two days afterwards; and being refused entrance at the workhouse because it was "full of mad people," was carried off, the "Pall Mall Gazette" says not where.

64. Now, gentlemen, the question I wish to leave with you to-day is whether the Wisdom * "Pall Mall Gazette," January 29th, I869. 
III. RELATION OF WISE ART TO WISE SCIENCE. 73

which rejoices in the habitable parts of the earth, and whose delights are with the sons of men, can be supposed, under circumstances such as these, to delight herself in that most closely and increasingly inhabited portion of the globe which we ourselves now dwell on ; and whether, if she cannot grant us to surpass the art of the swallow or the eagle, she may not require of us at least, to reach the level of their happiness. Or do you seriously think that, either in the life of Ludgate Hill, or death of the Isle of Dogs; in the art of Ludgate Hill, or idleness of the Isle of Dogs; and in the science and sanity of Ludgate Hill, or nescience and insanity of the Isle of Dogs, we have, as matters stand now, any clear encouragement to repeat, in that IO3rd psalm, the three verses following the five I named; and to believe in our hearts, as we say with our lips, that we have yet, dwelling among us, unoffended, a God "who forgiveth all our iniquities, who healeth all our diseases; who redeemeth our life from destruction, who crowneth us with loving-kindness and tender mercies, and who satisfieth our mouth with good things, so that our youth is RENEWED LIKE THE EAGLE'S"? 


\section{LECTURE IV.}

THE POWER OF MODESTY IN SCIENCE AND ART.

$$
\text { I7th February, } 1872 .
$$

65. I BELIEVE, gentlemen, that some of you must have been surprised,-and, if I succeeded in making my last lecture clearly intelligible, many ought to have been surprised,-at the limitations I asked you to admit with respect to the idea of science, and the position which I asked you to assign to it. We are so much, by the chances of our time, accustomed to think of science as a process of discovery, that I am sure some of you must have been gravely disconcerted by my requesting, and will to-day be more disconcerted by my firmly recommending, you to use the word, and reserve the thought, of science, for the acquaintance with things long since discovered, and established as true. We have the misfortune to live in an epoch of transition from irrational dulness to irrational excitement; 
IV. POWER OF MODESTY IN SCIENCE AND ART. 75

and while once it was the highest courage of science to question anything, it is now an agony to her to leave anything unquestioned. So that, unawares, we come to measure the dignity of a scientific person by the newness of his assertions, and the dexterity of his methods in debate; entirely forgetting that science cannot become perfect, as an occupation of intellect, while anything remains to be discovered; nor wholesome as an instrument of education, while anything is permitted to be debated.

66. It appears, doubtless, a vain idea to you that an end should ever be put to discovery; but remember, such impossibility merely signifies that mortal science must remain imperfect. Nevertheless, in many directions, the limit to practically useful discovery is rapidly being approached; and you, as students, would do well to suppose that it has been already attained. To take the science of ornithology, for instance : I suppose you would have very little hope of shooting a bird in England, which should be strange to any master of the science, or of shooting one anywhere, which would not fall under some species already described. And although at the risk of life, and by the devotion 
of many years to observation, some of you might hope to bring home to our museum a titmouse with a spot on its tail which had never before been seen, I strongly advise you not to allow your studies to be disturbed by so dazzling a hope, nor your life exclusively devoted even to so important an object. In astronomy, the fields of the sky have not yet, indeed, been ransacked by the most costly instruments; and it may be in store for some of you to announce the existence, or even to analyse the materials, of some luminous point which may be seen two or three times in the course of a century, by any one who will journey to India for the purpose ; and, when there, is favoured by the weather. But, for all practical purposes, the stars already named and numbered are as many as we require to hear of; and if you thoroughly know the visible motions, and clearly conceive the known relations, even of those which can be seen by the naked eye, you will have as much astronomy as is necessary, either for the occupation of thought or the direction of navigation.

67. But, if you were discontented with the limit I proposed for your sciences, much more, I imagine, you were doubtful of the ranks I assigned 
to them. It is not, I know, in your modern system, the general practice to put chemistry, the science of atoms, lowest, and theology, the science of Deity, highest: nay, many of us have ceased to think of theology as a science at all, but rather as a speculative pursuit, in subject, separate from science; and in temper, opposed to her.

Yet it can scarcely be necessary for me to point out to you, in so many terms, that what we call theology, if true, is a science; and if false, is not theology; or that the distinction even between natural science and theology is illogical : for you might distinguish indeed between natural and unnatural science, but not between natural and spiritual, unless you had determined first that a spirit had no nature. You will find the facts to be, that entirely true knowledge is both possible and necessary-first of facts relating to matter, and then of the forces and passions that act on or in matter;-that, of all these forces, the noblest we can know is the energy which either imagines, or perceives, the existence of a living power greater than its own and that the study of the relations which exist between this energy, and the resultant action 
of men, are as much subjects of pure. science as the curve of a projectile. The effect, for instance, upon your temper, intellect, and conduct during the day, of your going to chapel with or without belief in the efficacy of prayer, is just as much a subject of definite science, as the effect of your breakfast on the coats of your stomach. Which is the higher knowledge, I have, with confidence, told you; and am not afraid of any test to which you may submit my assertion.

68. Assuming such limitation, then, and such rank, for our knowledge ; assuming, also, what I have now, perhaps to your weariness, told you, that graphic art is the shadow, or image, of knowledge,-I wish to point out to you to-day the function, with respect to both, of the virtue called by the Greeks ' $\sigma \omega \phi \rho o \sigma u ́ \nu \eta$,' 'safeness of mind,' corresponding to the 'salus ' or 'sanitas' mentis, of the Latins ; 'health of heart' is, perhaps, the best English ; if we receive the words 'mens,' ' $\mu \hat{\eta} \nu \iota s$, ' or ' $\phi \rho \eta \nu$, ' as expressing the passionate soul of the human being, distinguished from the intellectual; the 'mens sana' being possible to all of us, though the contemplative range of hieght her wisdom may be above our 
IV. POWER OF MODESTY IN SCIENCE AND ART. 79

capacities; so that to each of us Heaven only permits the ambition of being $\sigma o \phi o ́ s$, but commands the resolution to be $\sigma \omega \phi \rho \omega \nu$.

69. And, without discussing the use of the word by different writers, I will tell you that the learest and safest idea of the mental state itself is to be gained from the representations of it by the words of ancient Christian religion, and even from what you may think its superstitions. Without any discussion also as to the personal existence or traditional character of evil spirits, you will find it a practical fact, that external temptations and inevitable trials of temper, have power against you which your health and virtue depend on your resisting; that, if not resisted, the evil energy of them will pass into your own heart, $\phi \rho \eta^{\prime} \nu^{\prime}$ or $\mu \hat{\eta} \nu \iota \varsigma$; and that the ordinary and vulgarized phrase "the Devil, or betraying Spirit, is in him" is the most scientifically accurate which you can apply to any person so influenced. You will find also that, in the compass of literature, the casting out of, or cleansing from, such a state is best symbolized for you by the image of one who had been wandering wild and naked among tombs, sitting still, clothed, and in his right 
mind, and that in whatever literal or figurative sense you receive the Biblical statement of what followed, this is absolutely certain, that the herd of swine hastening to their destruction, in perfect sympathy with each other's fury, is the most accurate symbol ever given, in literature, of consummate human $a \dot{\phi} \rho \circ \sigma u ́ v \eta$.

$$
\text { * * * * * }
$$

(The conditions of insanity,* delighting in scenes of death, which affect at the present time the arts of revolutionary Europe, were illustrated in the sequel of this lecture : but I neither choose to take any permanent notice of the examples I referred to, nor to publish any part of what I said, until I can enter more perfectly into the analysis of the elements of evil passion which always distorted and polluted even the highest arts of Greek and Christian loyal religion; and now occupy in deadly entireness, the chambers of imagination, devastated, and left desolate of joy, by impiety, and disobedience.

In relation to the gloom of gray colour characteristic especially of the modern French

* I use this word always meaning it to be understood literally, and in its full force. 
IV. POWER OF MODESTY IN SCIENCE AND ART. 8 I

revolutionary school, I entered into some examination of the conditions of real temperance and reserve in colour, showing that it consisted not in refusing colour, but in governing it; and that the most pure and bright colours might be thus perfectly governed, while the most dull were probably also the most violent and intemperate. But it would be useless to print this part of the lecture without the colour-illustrations used.

Passing to the consideration of intemperance and immodesty in the choice even of landscape subjects, I referred thus for contrast, to the quietude of Turner's “Greta and Tees.”)

70. If you wish to feel the reserve of this drawing, look, first, into the shops at their display of common chromo-lithotints; see how they are made up of Matterhorns, Monte Rosas, blue glaciers, green lakes, white towers, magnificent banditti, romantic peasantry, or alwayssuccessful sportsmen or fishermen in Highland costume; and then see what Turner is content with. No Matterhorns are needful, or even particularly pleasing to him. A bank, some eight or ten feet high, of Yorkshire shale is enough. He would not thank you for giving him all the 
giant forests of California :-would not be so much interested in them nor half so happy among them, as he is here with a switch of oak sapling, which the Greta has pulled down among the stones, and teased awhile, and which, now that the water is lower, tries to get up again, out of its way.

He does not want any towers or towns. Here you are to be contented with three square windows of a country gentleman's house. He does not want resplendent banditti. Behold! here is a brown cow and a white one: what would you have more? And this scarcely-falling rapid of the Tees-here pausing to circle round a pool, and there laughing as it trips over a ledge of rock, six or seven inches high, is more to him-infinitely more-than would be the whole colossal drainage of Lake Erie into Lake Ontario, which Carlyle has justly taken for a type of the Niagara of our national precipitous á $\phi \rho o \sigma u ́ v \eta$.

7 I. I need not point out to you the true temperance of colour in this drawing-how slightly green the trees are, how softly blue the sky.

Now I put a chromo-lithotint beside it.

Well, why is that good, this bad? Simply 
IV. POWER OF MODESTY IN SCIENCE AND ART. 83

because if you think, and work, and discipline yourselves nobly, you will come to like the Greta and Tees; if not, you will come to like this. The one is what a strong man likes; the other what a weak one likes : that is modest, full of true ai $\delta$ 's, noble restraint, noble reverence ;this has no aidìs, no fear, no measure;-not even purpose, except, by accumulation of whatever it can see or snatch, to move the vile apathy

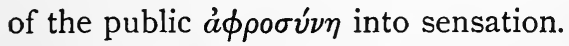

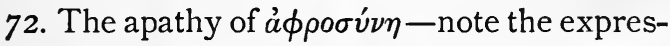
sion! You might think that it was $\sigma \omega \phi \rho o \sigma u ́ v \eta$, which was apathetic, and that intemperance was full of passion. No; the exact contrary is the fact. It is death in ourselves which seeks the exaggerated external stimulus. I must return for a moment to the art of modern France.

The most complete rest and refreshment I can get, when I am overworked, in London (for if I try to rest in the fields, I find them turned into villas in the course of the week before) is in seeing a French play. But the French act so perfectly that I am obliged to make sure beforehand that all is to end well, or it is as bad as being helplessly present at some real misery.

I was beguiled the other day, by seeing it 
announced as a "Comédie," into going to see "Frou-Frou." Most of you probably know that the three first of its five acts are comedy, or at least playful drama, and that it plunges down, in the two last, to the sorrowfullest catastrophe of all conceivable-though too frequent in daily life - in which irretrievable grief is brought about by the passion of a moment, and the ruin of all that she loves, caused by the heroic error of an entirely good and unselfish person. The sight of it made me thoroughly ill, and I was not myself again for a week.

But, some time afterwards, I was speaking of it to a lady who knew French character well; and asked her how it was possible for a people so quick in feeling to endure the action before them of a sorrow so poignant. She said, "It is because they have not sympathy enough: they are interested only by the external scene, and are, in truth, at present, dull, not quick in feeling. My own French maid went the other evening to see that very play: when she came home, and I asked her what she thought of it, she said 'it was charming, and she had amused herself immensely.' 'Amused! but is not the story very sad ?' 'Oh, yes, mademoiselle, it is bien 
IV. POWER OF MODESTY IN SCIENCE AND ART. 85

triste, but it is charming ; and then, how pretty Frou-Frou looks in her silk dress !'"

73. Gentlemen, the French maid's mode of regarding the tragedy is, if you think of it, a most true image of the way in which fashionable society regards the world-suffering, in the midst of which, so long as it can amuse itself, all seems to it well. If the ball-room is bright, and the dresses pretty, what matter how much horror is beneath or around? Nay, this apathy checks us in our highest spheres of thought, and chills our most solemn purposes. You know that I never join in the common outcries against Ritualism; yet it is too painfully manifest to me that the English Church itself has withdrawn her eyes from the tragedy of all churches, to perk herself up anew with casement and vestment, and say of herself, complacently, in her

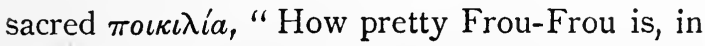
her silk dress !"

74. We recognize, however, without difficulty, the peril of insatiableness and immodesty in the pleasures of Art. Less recognized, but therefore more perilous, the insatiableness and immodesty of Science tempt us through our. very virtues. The fatallest furies of scientific 
$a \phi \rho o \sigma u ́ v \eta$ are consistent with the most noble powers of self-restraint and self-sacrifice. It is not the lower passions, but the loftier hopes and most honourable desires which become deadliest when the charm of them is exalted by the vanity of science. The patience of the wisest of Greek heroes never fails, when the trial is by danger or pain; but do you recollect that, before his trial by the song of the Sirens, the sea becomes calm?. And in the few words which Homer has told you of their song, you have not perhaps yet with enough care observed that the form of temptation is precisely that to which a man victorious over every fleshly trial would be likely to yield. The promise is not that his body shall be gratified, but that his soul shall rise into rapture; he is not urged, as by the subtlety of Comus, to disdain the precepts of wisdom, but invited, on the contrary, to learn,-as you are all now invited by the

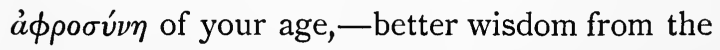
wise.

"For we know all" (they say) "that was done in Troy according to the will of the gods, and we know everything that is upon the allnourishing earth." 
IV. POWER OF MODESTY IN SCIENCE AND ART. 87

All heavenly and earthly knowledge, you sec. I will read you Pope's expansion of the verses ; for Pope never alters idly, but always illustrates when he expands.

"Oh stay, oh pride of Greece !

(You hear, they begin by flattery).

Ulysses, stay,

Oh cease thy course, and listen to our lay.

Blest is the man ordained our voice to hear,

The song instructs the soul, and charms the ear.

Approach! Thy soul shall into raptures rise;

Approach! and learn new wisdom from the wise.

We know whate'er the kings of mighty name

Achieved at Ilion in the field of Fame,

Whate'er beneath the Sun's bright journey lies.

$\mathrm{Oh}$, stay, and learn new wisdom from the wise."

Is it not singular that so long ago the danger of this novelty of wisdom should have been completely discerned? Is it not stranger still that three thousand years have passed by, and we have not yet been able to learn the lesson, but are still eager to add to our knowledge, rather than to use it ; and every day more passionate in discovering,--more violent in competition,are every day more cold in admiration, and more dull in reverence? 
88 THE EAGLE'S NEST.

75. But, gentlemen, Homer's Ulysses, bound to the mast, survives. Dante's Ulysses is bound to the mast in another fashion. He, notwithstanding the protection of Athena, and after all his victories over fate, is still restless under the temptation to seek new wisdom. He goes forth past the Pillars of Hercules, cheers his crew amidst the uncompassed solitudes of the Atlantic, and perishes in sudden Charybdis of the infinite sea. In hell, the restless flame in which he is wrapt continually, among the advisers of evil, is seen, from the rocks above, like the firefly's flitting to and fro ; and the waving garment of torture, which quivers as he speaks, and aspires as he moves, condemns him to be led in eternal temptation, and to be delivered from evil nevermore. 


\section{LECTURE V.}

THE POWER OF CONTENTMENT IN SCIENCE AND ART.

22nd February, 1872.

76. I must ask you, in order to make these lectures of any permanent use, to be careful in keeping note of the main conclusion at which we arrive in the course of each, and of the sequence of such results. In the first, I tried to show you that Art was only wise when unselfish in her labour; in the second, that Science was only wise when unselfish in her statement; in the third, that wise Art was the shadow, or visible reflection, of wise Science; and in the fourth, that all these conditions of good must be pursued temperately and peacefully. I have now farther to tell you that they must be pursued independently.

77. You have' not often heard me use that word " independence." And, in the sense in 
which of late it has been accepted, you have never heard me use it but with contempt. For the true strength of every human soul is to be dependent on as many nobler as it can discern, and to be depended upon, by as many inferior as it can reach.

But to-day I use the word in a widely different sense. I think you must have felt, in what amplification I was able to give you of the idea of wisdom as an unselfish influence in Art and Science, how the highest skill and knowledge were founded in human tenderness, and that the kindly Art-wisdom which rejoices in the habitable parts of the earth, is only another form of the lofty Scientific charity, which rejoices 'in the truth.' And as the first order of Wisdom is to know thyself-though the least creature that can be known-so the first order of Charity is to be sufficient for thyself, though the least creature that can be sufficed; and thus contented and appeased, to be girded and strong for the ministry to others. If sufficient to thy day is the evil thereof, how much more should be the good!

78. I have asked you to recollect one aphorism respecting Science, one respecting Art; let 
V. CONTENTMENT IN SCIENCE AND ART. 9I

me-and I will ask no more at this time of asking -press you to learn, farther, by heart, those lines of the Song of the Sirens: six lines of Homer, I trust, will not be a weariness to you-

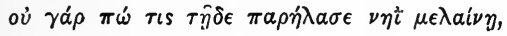

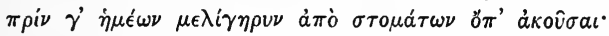

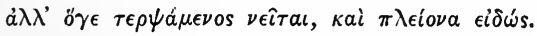

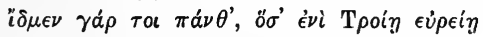

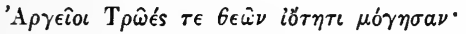

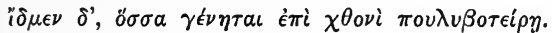

Ном., Od., xii. I 86.

"No one ever rowed past this way in his black ship, before he had listened to the honeysweet singing of our lips. But he stays pleased, though he may know much. For we know all things which the Greeks and Trojans did in the wide Trojan plain, by the will of the gods, and we know what things take place in the much nourishing earth." And this, remember, is absolutely true. No man ever went past in the black ship,-obeying the grave and sad law of life by which it is appointed for mortals to be victors on the ocean,- - but he was tempted, as he drew near that deadly island, wise as he might

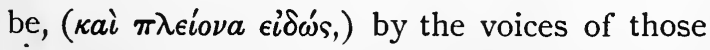
who told him that they knew everything which 
had been done by the will of God, and everything which took place in earth for the service of man.

79. Now observe those two great temptations. You are to know everything that has been done by the will of God: and to know everything that is vital in the earth. And try to realize to yourselves, for a little while, the way in which these two siren promises have hitherto troubled the paths of men. Think of the books that have been written in false explanation of Divine Providence : think of the efforts that have been made to show that the particular conduct which we approve in others, or wish ourselves to follow, is according to the will of God. Think what ghastly convulsions in thought, and vileness in action, have been fallen into by the sects which thought they had adopted, for their patronage, the perfect purposes of Heaven. Think of the vain research, the wasted centuries of those who have tried to penetrate the secrets of life, or of its support. The elixir vitæ, the philosopher's stone, the germ-cells in meteoric

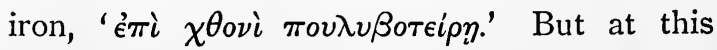
day, when we have loosed the last band from the masts of the black ship, and when, instead 
v. CONTENTMENT IN SCIENCE AND ART. 93

of plying every oar to escape, as the crew of Homer's Ulysses, we row like the crew of Dante's Ulysses, and of our oars make wings for our foolish flight,

\section{E, volta nostra poppe nel mattino \\ De' remi facemmo ale al folle volo-}

the song of the sirens becomes fatal as never yet it has been in time. We think ourselves privileged, first among men, to know the secrets of Heaven, and fulfil the economy of earth ; and the result is, that of all the races that yet have been put to shame by their false wisdom or false art,-which have given their labour for that which is not bread, and their strength for that which satisfieth not,-we have most madly abandoned the charity which is for itself sufficing, and for others serviceable, and have become of all creatures the most insufficient to ourselves, and the most malignant to our neighbours. Granted a given degree of knowledge

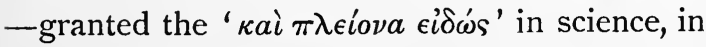
art, and in literature,-and the present relations of feeling between France and Germany, between England and America, are the most horrible at once in their stupidity and malignity, 
that have ever taken place on the globe we inhabit, even though all its great histories are of sin, and all its great songs, of death.

8o. Gentlemen, I pray you very solemnly to put that idea of knowing all things in Heaven and Earth out of your hearts and heads. It is very little that we can ever know, either of the ways of Providence, or the laws of existence. But that little is enough, and exactly enough: to strive for more than that little is evil for us ; and be assured that beyond the need of our narrow being,-beyond the range of the kingdom over which it is ordained for each of us to

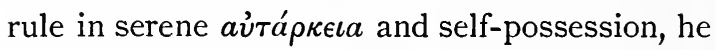
that increaseth toil, increaseth folly; and he that increaseth knowledge, increaseth sorrow.

8I. My endeavour, therefore, to-day will be to point out to you how in the best wisdom, that there may be happy advance, there must first be happy contentment ; that, in one sense, we must always be entering its kingdom as a little child, and pleased yet for a time not to put away childish things. And while I hitherto have endeavoured only to show how modesty and gentleness of disposition purified Art and Science, by permitting us to recognize the 
V. CONTENTMENT IN SCIENCE AND ART. 95

superiority of the work of others to our ownto-day, on the contrary, I wish to indicate for you the uses of infantine self-satisfaction; and to show you that it is by no error or excess in our nature, by no corruption or distortion of our being, that we are disposed to take delight in the little things that we can do ourselves, more than in the great things done by other people. So only that we recognize the littleness and the greatness, it is as much a part of true Temperance to be pleased with the little we know, and the little we can do, as with the little that we have. On the one side Indolence, on the other Covetousness, are as much to be blamed, with respect to our Arts, as our possessions; and every man is intended to find an exquisite personal happiness in his own small skill, just as he is intended to find happiness in his own small house or garden, while he respects, without coveting, the grandeur of larger domains.

82. Nay, more than this: by the wisdom of Nature, it has been appointed that more pleasure may be taken in small things than in great, and more in rude Art than in the finest Were it otherwise, we might be disposed to complain of 
the narrow limits which have been set to the perfection of human skill.

I pointed out to you, in a former lecture, that the excellence of sculpture had been confined in past time to the Athenian and Etrur- ian vales. The absolute excellence of painting has been reached only by the inhabitants of a single city in the whole world; and the faultless manner of religious architecture holds only for a period of fifty years out of six thousand. We are at present tormenting ourselves with the vain effort to teach men everywhere to rival Venice and Athens, - with the practical result of having lost the enjoyment of Art altogether ; -instead of being content to amuse ourselves still with the painting and carving which were possible once, and would be pleasant always, in Paris, and London, at Strasbourg, and at York.

I do not doubt that you are greatly startled at my saying that greater pleasure is to be received from inferior Art than from the finest. But what do you suppose makes all men look back to the time of childhood with so much regret, (if their childhood has been, in any moderate degree, healthy or peaceful)? That 
V. CONTENTMENT IN SCIENCE AND ART. 97

rich charm, which the least possession had for us, was in consequence of the poorness of our treasures. That miraculous aspect of the nature around us, was because we had seen little, and knew less. Every increased possession loads us with a new weariness; every piece of new knowledge diminishes the faculty of admiration ; and Death is at last appointed to take us from a scene in which, if we were to stay longer, no gift could satisfy us, and no miracle surprise.

83. Little as I myself know, or can do, as compared with any man of essential power, my life has chanced to be one of gradual progress in the things which I began in childish choice; $\approx$ so that I can measure with almost mathematical exactitude the degree of feeling with which less and greater degrees of wealth or skill affect my mind.

I well remember the delight with which, when I was beginning mineralogy, I received from a friend, who had made a voyage to Peru, a little bit of limestone about the size of a hazel nut, with a small film of native silver adhering to its surface. I was never weary of contemplating my treasure, and could not have felt myself richer had I been master of the mines of Copiapo.

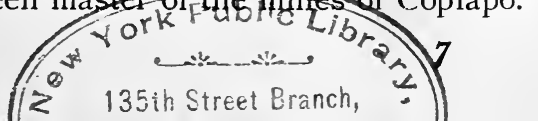


I am now about to use as models for your rock drawings stones which my year's income, when I was a boy, would not have bought. But I have long ceased to take any pleasure in their possession ; and am only thinking, now, to whom else they can be of use, since they can be of no more to me.

84. But the loss of pleasure to me caused by advance in knowledge of drawings has been far greater than that induced by my riches in minerals.

I have placed, in your reference series, one or two drawings of architecture, made when I was a youth of twenty, with perfect ease to myself, and some pleasure to other people. A day spent in sketching then brought with it no weariness, and infinite complacency. I know better now what drawing should be; the effort to do my work rightly fatigues me in an hour, and I never care to look at it again from that day forward.

85. It is true that men of great and real power do the best things with comparative ease; but you will never hear them express the complacency which simple persons feel in partial success. There is nothing to be regretted in 
this ; it is appointed for all men to enjoy, but for few to achieve.

And do not think that I am wasting your time in dwelling on these simple moralities. From the facts I have been stating we must derive this great principle for all effort. That we must endeavour to do, not what is absolutely best, but what is easily within our power and adapted to our temper and condition.

86. In your educational series is a lithographic drawing, by Prout, of an old house in Strasbourg. The carvings of its woodwork are in a style altogether provincial, yet of which the origin is very distant. The delicate Renaissance architecture of Italy was affected, even in its finest periods, by a tendency to throw out convex masses at the bases of its pillars; the wood-carvers of the I6th century adopted this bulged form as their first element of ornamentation, and these windows of Strasbourg are only imitations by the German peasantry of what, in its finest type, you must seek as far away as the Duomo of Bergamo.

But the burgher, or peasant, of Alsace enjoyed his rude imitation, adapted, as it was, boldly and frankly to the size of his house and 
the grain of the larch logs of which he built it, infinitely more than the refined Italian enjoyed the floral luxuriance of his marble; and all the treasures of a great exhibition could not have given him the tenth part of the exultation with which he saw the gable of his roof completed over its jutting fret-work; and wrote among the rude intricacies of its sculpture, in flourished black letter, that "He and his wife had built their house with God's help, and prayed Him to let them live long in it,-they, and their children."

87. But it is not only the rustic method of architecture which I wish you to note in this plate; it is the rustic method of drawing also. The manner in which these blunt timber carvings are drawn by Prout is just as provincial as the carvings themselves. Born in a faraway district of England, and learning to draw, unhelped, with fishing-boats for his models; making his way instinctively until he had command of his pencil enough to secure a small income by lithographic drawing; and finding picturesque character in buildings from which all the finest lines of their carving had been effaced by time; possessing also an instinct in the expression of such subjects so peculiar as to win 
V. CONTENTMENT IN SCIENCE AND ART. IOI

for him a satisfying popularity, and, far better, to enable him to derive perpetual pleasure in the seclusion of country hamlets, and the quiet streets of deserted cities, - Prout had never any motive to acquaint himself with the refinements, or contend with the difficulties, of a more accomplished art. So far from this, his manner of work was, by its very imperfection, in the most perfect sympathy with the subjects he enjoyed. The broad chalk touches in which he has represented to us this house at Strasbourg are entirely sufficient to give true idea of its effect. To have drawn its ornaments with subtlety of Leonardesque delineation would only have exposed their faults, and mocked their rusticity. The drawing would have become painful to you from the sense of the time which it had taken to represent what was not worth the labour, and to direct your attention to what could only, if closely examined, be matter of offence. But here you have a simple and provincial draughtsman happily and adequately expressing a simple and provincial architecture; nor could either builder or painter have become wiser, but to their loss.

88. Is it then, you will ask me, seriously to 
be recommended, and, however recommendable, is it possible, that men should remain contented with attainments which they know to be imperfect? and that now, as in former times, large districts of country, and generations of men, should be enriched or amused by the products of a clumsy ignorance? I do not know how far it is possible, but I know that wherever you desire to have true art, it is necessary. Ignorance, which is contented and clumsy, will produce what is imperfect, but not offensive. But ignorance discontented and dexterous, learning what it cannot understand, and imitating what it cannot enjoy, produces the most loathsome forms of manufacture that can disgrace or mislead humanity. Some years since, as I was looking through the modern gallery at the quite provincial German School of Düsseldorf, I was fain to leave all their epic and religious designs, that I might stay long before a little painting of a shepherd boy carving his dog out of a bit of deal. The dog was sitting by, with the satisfied and dignified air of a personage about for the first time in his life to be worthily represented in sculpture; and his master was evidently succeeding to his mind in expressing 
v. CONTENTMENT IN SCIENCE AND ART. IO3

the features of his friend. The little scene was one which, as you know, must take place continually among the cottage artists who supply the toys of Nuremberg and Berne. Happy, these! so long as, undisturbed by ambition, they spend their leisure time in work pretending only to amuse, yet capable, in its own way, of showing accomplished dexterity, and vivid perception of nature. We, in the hope of doing great things, have surrounded our workmen with Italian models, and tempted them with prizes into competitive mimicry of all that is best, or that we imagine to be best, in the work of every people under the sun. And the result of our instruction is only that we are able to produce,-I am now quoting the statement I made last May, "the most perfectly and roundly ill-done things" that ever came from human hands. I should thankfully put upon my chimney-piece the wooden dog cut by the shepherd boy; but I should be willing to forfeit a large sum rather than keep in my room the number I of the Kensington Museum-thus described in its catalogue-" Statue in black and white marble, of a Newfoundland dog standing on a serpent, which rests on a marble cushion;-the 
pedestal ornamented with Pietra Dura fruits in relief."

89. You will, however, I fear, imagine me indulging in my usual paradox, when I assure you that all the efforts we have been making to surround ourselves with heterogeneous means of instruction, will have the exactly reverse effect from that which we intend;-and that, whereas formerly we were able only to do a little well, we are qualifying ourselves now to do everything ill. Nor is the result confined to our workmen only. The introduction of French dexterity and of German erudition has been harmful chiefly to our most accomplished artists - and in the last Exhibition of our Royal Academy there was, I think, no exception to the manifest fact that every painter of reputation painted worse than he did ten years ago.

90. Admitting, however, (not that I suppose you will at once admit, but for the sake of argument, supposing,) that this is true, what, we have further to ask, can be done to discourage ourselves from calamitous emulation, and withdraw our workmen from the sight of what is too good to be of use to them?

But this question is not one which can be 
V. CONTENTMENT IN SCIENCE AND ART. IO5

determined by the needs, or limited to the circumstances of Art. To live generally more modest and contented lives; to win the greatest possible pleasure from the smallest things; to do what is likely to be serviceable to our immediate neighbours, whether it seem to them admirable or not ; to make no pretence of admiring what has really no hold upon our hearts; and to be resolute in refusing all additions to our learning, until we have perfectly arranged and secured what learning we have got;-these are conditions, and laws, of unquestionable $\sigma o \phi i ́ a$ and $\sigma \omega \phi \rho o \sigma v ́ \nu \eta$, which will indeed lead us up to fine art if we are resolved to have it fine; but will also do what is much better, make rude art precious.

9I. It is not, however, by any means necessary that provincial art should be rude, though it may be singular. Often it is no less delicate than quaint, and no less refined in grace than original in character. This is likely always to take place when a people of naturally fine artistic temper work with the respect which, as I endeavoured to show you in a former lecture, ought always to be paid to local material and circumstance. 
I have placed in your educational series the photograph of the door of a wooden house in Abbeville, and of the winding stair above; both so exquisitely sculptured that the real vineleaves which had wreathed themselves about their pillars, cannot, in the photograph, be at once discerned from the carved foliage. The latter, quite as graceful, can only be known for art by its quaint setting.

Yet this school of sculpture is altogether provincial. It could only have risen in a richlywooded chalk country, where the sapling trees beside the brooks gave example to the workman of the most intricate tracery, and the white cliffs above the meadows furnished docile material to his hand.

92. I have now, to my sorrow, learned to despise the elaborate intricacy, and the playful realizations, of the Norman designers ; and can only be satisfied by the reserved and proud imagination of the master schools. But the utmost pleasure I now take in these is almost as nothing, compared to the joy I used to have, when I knew no better, in the fretted pinnacles of Rouen, and white lace, rather than stonework, of the chapels of Reu and Amboise. 
v. CONTENTMENT IN SCIENCE AND ART. IO7

Yet observe that the first condition of this really precious provincial work is its being the best that can be done under the given circumstances; and the second is, that though provincial, it is not in the least frivolous or ephemeral, but as definitely civic, or public, in design, and as permanent in the manner of it, as the work of the most learned academies: while its execution brought out the energies of each little state, not necessarily in rivalship, but severally in the perfecting of styles which Nature had rendered it impossible for their neighbours to imitate.

93. This civic unity, and the feeling of the workman that he is performing his part in a great scene which is to endure for centuries, while yet, within the walls of his city, it is to be a part of his own peculiar life, and to be separate from all the world besides, developes, together, whatever duty he acknowledges as a patriot, and whatever complacency he feels as an artist.

We now build, in our villages, by the rules of the Academy of London; and if there be a little original vivacity or genius in any provincial workman, he is almost sure to spend it in 
making a ridiculous toy. Nothing is to me much more pathetic than the way that our neglected workmen thus throw their lives away. As I was walking the other day through the Crystal Palace, I came upon a toy which had taken the leisure of five years to make; you dropped a penny into the chink of it, and immediately a little brass steam-engine in the middle started into nervously hurried action; some bell-ringers pulled strings at the bottom of a church steeple which had no top; two regiments of cavalry marched out from the sides, and manœuvred in the middle; and two well-dressed persons in a kind of opera-box expressed their satisfaction by approving gestures.

In old Ghent, or Bruges, or York, such a man as the one who made this toy, with companions similarly minded, would have been taught how to employ himself, not to their less amusement, but to better purpose ; and in their five years of leisure hours they would have carved a flamboyant crown for the belfry-tower, and would have put chimes into it that would have told the time miles away, with a pleasant tune for the hour, and a variation for the quarters, and cost the passers-by in all the city 
V. CONTENTMENT IN SCIENCE AND ART. IO9

and plain not so much as the dropping of a penny into a chink.

94. Do not doubt that I feel, as strongly as any of you can feel, the utter impossibility at present of restoring provincial simplicity to our country towns.

My despondency respecting this, and nearly all other matters which I know to be necessary, is at least as great,-it is certainly more painful to me,-in the decline of life,-than that which any of my younger hearers can feel. But what I have to tell you of the unchanging principles of nature, and of art, must not be affected by either hope or fear. And if I succeed in convincing you what these principles are, there are many practical consequences which you may deduce from them, if ever you find yourselves, as young Englishmen are often likely to find themselves, in authority over foreign tribes of peculiar or limited capacities.

Be assured that you can no more drag or compress men into perfection than you can drag or compress plants. If ever you find yourselves set in a position of authority, and are entrusted to determine modes of education, ascertain first what the people you would teach have been in 
the habit of doing, and encourage them to do that better. Set no other excellence before their eyes; disturb none of their reverence for the past; do not think yourselves bound to dispel their ignorance, or to contradict their superstitions; teach them only gentleness and truth; redeem them by example from habits which you know to be unhealthy or degrading; but cherish, above all things, local associations, and hereditary skill.

It is the curse of so-called civilization to pretend to originality by the wilful invention of new methods of error, while it quenches wherever it has power, the noble originality of nations, rising out of the purity of their race, and the love of their native land.

95. I could say much more, but I think I have said enough to justify for the present what you might otherwise have thought singular in the methods I shall adopt for your exercise in the drawing schools. I shall indeed endeavour to write down for you the laws of the art which is centrally best ; and to exhibit to you a certain number of its unquestionable standards: but your own actual practice shall be limited to objects which will explain to you the meaning, 
V. CONTENTMENT IN SCIENCE AND ART. I I I

and awaken you to the beauty, of the art of your own country.

The first series of my lectures on sculpture must have proved to you that I do not despise either the workmanship or the mythology of Greece; but I must assert with more distinctness than even in my earliest works, the absolute unfitness of all its results to be made the guides of English students or artists.

Every nation can represent, with prudence, or success, only the realities in which it delights. What you have with you, and before you, daily, dearest to your sight and heart, that, by the magic of your hand, or of your lips, you can gloriously express to others; and what you ought to have in your sight and heart,--what, if you have not, nothing else can be truly seen or loved,-is the human life of your own people, understood in its history, and admired in its presence.

And unless that be first made beautiful, idealism must be false and imagination monstrous.

It is your influence on the existing world which, in your studies here, you ought finally to consider ; and although it is not, in that influence, my function to direct you, I hope you 
will not be discontented to know that I shall ask no effort from your art-genius, beyond the rational suggestion of what we may one day hope to see actually realized in England, in the sweetness of her landscape, and the dignity of her people.

In connection with the subject of this lecture, I may mention to you that I have received an interesting letter, requesting me to assist in promoting some improvements designed in the city of Oxford.

But as the entire charm and educational power of the city of Oxford, so far as that educational power depended on reverent associations, or on visible solemnities and serenities of architecture, have been already destroyed; and, as far as our own lives extend, destroyed, I may say, for ever, by the manufacturing suburb which heaps its ashes on one side, and the cheap-lodging suburb which heaps its brickbats on the other; I am myself, either as antiquary or artist, absolutely indifferent to what happens next; except on grounds respecting the possible health, cleanliness, and decency which may yet be obtained for the increasing population. 
V. CONTENTMENT IN SCIENCE AND ART. II 3

How far cleanliness and decency bear on art and science, or on the changed functions of the university to its crowd of modern students, I have partly to consider in connection with the subject of my next lecture, and I will reserve therefore any definite notice of these proposed improvements in the city, until the next occasion of meeting you. 


\section{LECTURE VI.}

THE RELATION TO ART OF THE SCIENCE OF LIGHT.

$$
\text { 24th February, } 1872 .
$$

96. I HAVE now, perhaps to the exhaustion of your patience, but you will find, not without real necessity, defined the manner in which the mental tempers, ascertained by philosophy to be evil or good, retard and advance the parallel studies of science and art.

In this and the two next following lectures I shall endeavour to state to you the literal modes in which the virtues of art are connected with the principles of exact science ; but now, remember, I am speaking, not of the consummatescience of which art is the image; but only of what science we have actually attained, which is often little more than terminology (and even that uncertain), with only a gleam of true science here and there.

I will not delay you by any defence of the 
VI. RELATION TO ART OF SCIENCE OF LIGHT. I I 5

arrangement of sciences I havechosen. Of course we may at once dismiss chemistry and pure mathematics from our consideration. Chemistry can do nothing for art but mix her colours, and tell her what stones will stand weather; (I wish, at this day, she did as much;) and with pure mathematics we have nothing whatever to do; nor can that abstract form of high mathesis stoop to comprehend the simplicity of art. To a first wrangler at Cambridge, under the present conditions of his trial, statues will necessarily be stone dolls, and imaginative work unintelligible. We have, then, in true fellowship with art, only the sciences of light and form, (optics and geometry). If you will take the first syllable of the word 'geometry' to mean earth in the form of flesh, as well as of clay, the two words sum every science that regards graphic art, or of which graphic art can represent the conclusions.

97. To-day we are to speak of optics, the science of seeing; - of that power, whatever it may be, which (by Plato's definition), "through the eyes, manifests colour to us."

Hold that definition always, and remember that 'light' means accurately the power that affects the eyes of animals with the sensation 
proper to them. The study of the effect of light on nitrate of silver is chemistry, not optics ; and what is light to us may indeed shine on a stone ; but is not light to the stone. The "fiat lux" of creation is, therefore, in the deep sense of it, "fiat anima."

We cannot say that it is merely "fiat oculus," for the effect of light on living organism, even when sightless, cannot be separated from its influence on sight. A plant consists essentially of two parts, root and leaf : the leaf by nature seeks light, the root by nature seeks darkness : it is not warmth or cold, but essentially light and shade, which are. to them, as to us, the appointed conditions of existence.

98. And you are to remember still more distinctly that the words "fiat lux" mean indeed "fiat anima," because even the power of the eye itself, as such, is in its animation. You do not see with the lens of the eye. You see through that, and by means of that, but you see with the soul of the eye.

99. A great physiologist said to me the other day-it was in the rashness of controversy, and ought not to be remembered, as a deliberate assertion, therefore I do not give his name, still 
VI. RELATION TO ART OF SCIENCE OF LIGHT. I I 7

he did say-that sight was "altogether mechanical." The words simply meant, if they meant anything, that all his physiology had never taught him the difference between eyes and telescopes. Sight is an absolutely spiritual phenomenon; accurately, and only, to be so defined; and the "Let there be light," is as much, when you understand it, the ordering of intelligence, as the ordering of vision. It is the appointment of change of what had been else only a mechanical effluence from things unseen to things unseeing, - from stars that did not shine to earth that could not perceive; - - the change, I say, of that blind vibration into the glory of the sun and moon for human eyes; so rendering possible also the communication out of the unfathomable truth, of that portion of truth which is good for us, and animating to us, and is set to rule over the day and night of our joy and sorrow.

IOO. The sun was set thus ' to rule the day.' And of late you have learned that he was set to rule everything that we know of. You have been taught that, by the Sirens, as a piece of entirely new knowledge, much to be exulted over. We painters, indeed, have been for some time acquainted with the general look of the sun, 
and long before there were painters there were wise men,-Zoroastrian and other,-who had suspected that there was power in the sun; but the Sirens of yesterday have somewhat new, it seems, to tell you of his authority, є̇i $\chi \theta 0 \nu i$ $\pi$ ov $\lambda v \beta$ Котеi $\eta$. I take a passage, almost at random, from a recent scientific work.

"Just as the phenomena of water-formed rocks all owe their existence directly or indirectly chiefly to the sun's energy, so also do the phenomena interwoven with life. This has long been recognised by various eminent British and foreign physicists ; and in I 854 Professor in his memoir on the method of palæontology, asserted that organisms were but manifestations of applied physics and applied chemistry. Professor — puts the generalisations of physicists in a few words: When speaking of the sun, it is remarked-' He rears the whole vegetable world, and through it the animal ; the lilies of the field are his workmanship, the verdure of the meadows, and the cattle upon a thousand hills. He forms the muscle, he urges the blood, he builds the brain. His fleetness is in the lion's foot; he springs in the panther, he soars in the eagle, he slides in the snake. He builds the forest 
and hews it down, the power which raised the tree and that which wields the axe being one and the same.'"

All this is exceedingly true; and it is new in one respect, namely, in the ascertainment that the quantity of solar force necessary to produce motive power is measurable, and, in its sum, unalterable. For the rest, it was perfectly well known in Homer's time, as now, that animals could not move till they were warm; and the fact that the warmth which enables them to do so is finally traceable to the sun, would have appeared to a Greek physiologist, no more interesting than, to a Greek poet, would have been the no less certain fact, that "Tout ce qui se peut dire de beau est dans les dictionnaires; il n'y a que les mots qui sont transposés "-Everything fine, that can be said, is in the dictionaries; it is only that the words are transposed.

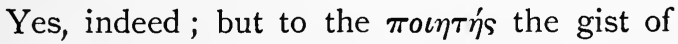
the matter is in the transposition. The sun does, as the delighted physicist tells you, unquestionably " slide in the snake;" but how comes he to adopt that manner, we artists ask, of (literally) transposition?

IOI. The summer before last, as I was walking 
in the woods near the Giesbach, on the Lake of Brientz, and moving very quietly, I came suddenly on a small steel-gray serpent, lying in the middle of the path; and it was greatly surprised to see me. Serpents, however, always have complete command of their feelings, and it looked at me for a quarter of a minute without the slightest change of posture: then, with an almost imperceptible motion, it began to withdraw itself beneath a cluster of leaves. Without in the least hastening its action, it gradually concealed the whole of its body. I was about to raise one of the leaves, when I saw what I thought was the glance of another serpent, in the thicket at the path side; but it was the same one, which having once withdrawn itself from observation beneath the leaves, used its utmost agility to spring into the wood; and with so instantaneous a flash of motion, that I never saw it leave the covert, and only caught the gleam of light as it glided away into the copse.

I02. Now, it was to me a matter of supreme indifference whether the force which the creature used in this action was derived from the sun, the moon, or the gas-works at Berne. What was, indeed, a matter of interest to me, was just 
that which would have struck a peasant, or a child;-namely, the calculating wisdom of the creature's device; and the exquisite grace, strength, and precision of the action by which it was accomplished.

I03. I was interested then, I say, more in the device of the creature, than in its source of motion. Nevertheless, I am pleased to hear, from men of science, how necessarily that motion proceeds from the sun. But where did its device come from? There is no wisdom, no device in the dust, any more than there is warmth in the dust. The springing of the serpent is from the sun :- the wisdom of the serpent,-whence that?

I04. From the sun also, is the only answer, I suppose, possible to physical science. It is not a false answer: quite true, like the other, up to a certain point. To-day, in the strength of your youth, you may know what it is to have the power of the sun taken out of your arms and legs. But when you are old, you will know what it is to have the power of the sun taken out of your minds also. Such a thing may happen to you, sometimes, even now ; but it will continually happen to you when you are my age. 
You will no more, then, think over a matter to any good purpose after twelve o'clock in the day. It may be possible to think over, and, much more, to talk over, matters, to little, or to bad, purpose after twelve o'clock in the day. The members of your national legislature do their work, we know, by gaslight; but you don't suppose the power of the sun is in any of their devices? Quite seriously, all the vital functions, - and, like the rest and with the rest, the pure and wholesome faculties of the brain,-rise and set with the sun : your digestion and intellect are alike dependent on its beams; your thoughts, like your blood, flow from the force of it, in all scientific accuracy and necessity. Sol illuminatio nostra est; Sol salus nostra; Sol sapientia nostra.

And it is the final act and outcome of lowest national atheism, since it cannot deny the sun, at least to strive to do without it; to blast the day in heaven with smoke, and prolong the dance, and the council, by night, with tapers, until at last, rejoicing-Dixit insipiens in corde suo, non est Sol.

I05. Well, the sliding of the serpent, and the device of the serpent, we admit, come from the 
VI. RELATION TO ART OF SCIENCE OF LIGHT. I23

sun. The flight of the dove, and its harmlessness,-do they also?

The flight,-yes, assuredly. The Innocence? -It is a new question. How of that ? Between movement and non-movement-nay, between sense and non-sense-the difference rests, we say, in the power of Apollo; but between malice and innocence, where shall we find the root of that distinction?

I06. Have you ever considered how much liceral truth there is in the words- "The light of the body is the eye. If, therefore, thine eye be evil"-and the rest? How can the eye be evil? How, if evil, can it fill the whole body with darkness?

What is the meaning of having one's body full of darkness? It cannot mean merely being blind. Blind, you may fall in a ditch if you move; but you may be well, if at rest. But to be evileyed, is not that worse than to have no eyes? and instead of being only in darkness, to have darkness in $u s$, portable, perfect, and eternal ?

I07. Well, in order to get at the meaning we may, indeed, now appeal to physical science, and ask her to help us. How many manner of eyes are there? You physical-science students should 
be able to tell us painters that. We only know, in a vague way, the external aspect and expression of eyes. We see, as we try to draw the endlessly-grotesque creatures about us, what infinite variety of instruments they have; but you know, far better than we do, how those instruments are constructed and directed. You know how some play in their sockets with independent revolution,-project into near-sightedness on pyramids of bone,-are brandished at the points of horns, - studded over backs and shoulders,-thrust at the ends of antennæ to pioneer for the head, or pinched up into tubercles at the corners of the lips. But how do the creatures see out of all these eyes?

108. No business of ours, you may think? Pardon me. This is no Siren's question - this is altogether business of ours, lest, perchance, any of us should see partly in the same manner. Comparative sight is a far more important question than comparative anatomy. It is no matter, though we sometimes walk-and it may often be desirable to climb-like apes; but suppose we only see like apes, or like lowor creatures ? I can tell you, the science of optics is an essential one to us; for exactly according to these 
VI. RELATION TO ART OF SCIENCE OF LIGHT. I 25

infinitely grotesque directions and multiplications of instrument, you have correspondent, not only intellectual but moral, faculty in the soul of the creatures. Literally, if the eye be pure, the body is pure ; but, if the light of the body be but darkness, how great is that darkness !

I09. Have you ever looked attentively at the study I gave you of the head of the rattle-snake? The serpent will keep its eyes fixed on you for an hour together, a vertical slit in each admitting such image of you as is possible to the rattlesnake retina, and to the rattlesnake mind. How much of you do you think it sees? I ask that, first, as a pure physical question. I do not know ; it is not my business to know. You, from your schools of physical science, should bring me answer. How much of a man can a snake see? What sort of image of him is received through that deadly vertical cleft in the iris;-through the glazed blue of the ghastly lens? Make me a picture of the appearance of a man, as far as you can judge it can take place on the snake's retina. Then ask yourselves, farther, kow much of speculation is possible to the snake, touching this human aspect?

I IO. Or, if that seem too far beneath possible 
inquiry, how say you of a tiger's eye, or a cat's? A cat may look at a king;-yes; but can it see a king when it looks at him? The beasts of prey never seem to me to look, in our sense, at all. Their eyes are fascinated by the motion of anything, as a kitten's by a ball;-they fasten, as if drawn by an inevitable attraction, on their food. But when a cat caresses you, it never looks at you. Its heart seems to be in its back and paws, not its eyes. It will rub itself against you, or pat you with velvet tufts, instead of talons; but you may talk to it an hour together, yet not rightly catch its eye. Ascend higher in the races of being - to the fawn, the dog, the horse ; you will find that, according to the clearness of sight, is indeed the kindness of sight, and that at last the noble eyes of humanity look through humanity, from heart into heart, and with no mechanical vision. And the Light of the body is the eye-yes, and in happy life, the light of the heart also.

I I I. But now note farther: there is a mathematical power in the eye which may far transcend its moral power. When the moral power is feeble, the faculty of measurement, or of distinct delineation, may be supreme; and of 
comprehension none. But here, again, I want the help of the physical science schools. I believe the eagle has no scent, and hunts by sight, yet flies higher than any other bird. Now, I want to know what the appearance is to an eagle, two thousand feet up, of a sparrow in a hedge, or of a partridge in a stubble-field. What kind of definition on the retina do these brown spots take to manifest themselves as signs of a thing eatable; and if an eagle sees a partridge so, does it see everything else so ? And then tell me, farther, does it see only a square yard at a time, and yet, as it flies, take summary of the square yards beneath it? When next you are travelling by express sixty miles an hour, past a grass bank, try to see a grasshopper, and you will get some idea of an eagle's optical business, if it takes only the line of ground underneath it. Does it take more?

I 12. Then, besides this faculty of clear vision, you have to consider the faculty of metric vision. Neither an eagle, nor a kingfisher, nor any other darting bird, can see things with both their eyes at the same time as completely as you and I can; but think of their faculty of measurement as compared with ours! You will find that it 
takes you months of labour before you can acquire accurate power, even of deliberate estimate of distances with the eye ; it is one of the points to which, most of all, I have to direct your work. And the curious thing is that, given the degree of practice, you will measure ill or well with the eye in proportion to the quantity of life in you. No one can measure with a glance, when they are tired. Only the other day I got half an inch out of a foot, in drawing merely a coat of arms, because I was tired. But fancy what would happen to a swallow, if it was half an inch out in a foot, in flying round a corner !

II3. Well, that is the first branch of the questions which we want answered by optical science; - the actual distortion, contraction, and other modification, of the sight of different animals, as far as it can be known from the forms of their eyes. Then, secondly, we ourselves need to be taught the connection of the sense of colour with health; the difference in the physical conditions which lead us to seek for gloom, or brightness of hue; and the nature of purity in colour, first in the object seen, and then in the eye which prefers it.

* * * * * * *


VI. RELATION TO ART OF SCIENCE OF LIGHT. I 29

(The portion of lecture here omitted referred to illustrations of vulgarity and delicacy in colour, showing that the vulgar colours, even when they seemed most glaring, were in reality impure and dull; and destroyed each other by contention; while noble colour, intensely bright and pure, was nevertheless entirely governed and calm, so that every colour bettered and aided all the rest.)

I 4. You recollect how I urged you in my opening course of lectures rather to work in the school of crystalline colour than in that of shade.

Since I gave that first course of lectures, my sense of the necessity of this study of brightness primarily, and of purity and gaiety beyond all other qualities, has deeply been confirmed by the influence which the unclean horror and impious melancholy of the modern French school - most literally the school of death-has gained over the popular mind. I will not dwell upon the evil phrenzy to-day. But it is in order at once to do the best I can, in counteraction of its deadly influence, though not without other and constant reasons, that I give you heraldry, with all its splendour and its pride, its brightness 
of colour, and honourableness of meaning, for your main elementary practice.

I I 5. To-day I have only time left to press on your thoughts the deeper law of this due joy in colour and light.

On any morning of the year, how many pious supplications, do you suppose, are uttered throughout educated Europe for "light"? How many lips at least pronounce the word, and, perhaps, in the plurality of instances, with some distinct idea attached to it? It is true the speakers employ it only as a metaphor. But why is their language thus metaphorical ? If they mean merely to ask for spiritual knowledge or guidance, why not say so plainly, instead of using this jaded figure of speech? No boy goes to his father when he wants to be taught, or helped, and asks his father to give him 'light.' He asks what he wants, advice or protection. Why are not we also content to ask our Father for what we want, in plain English?

The metaphor, you will answer, is put into our mouths, and felt to be a beautiful and necessary one.

I admit it. In your educational series, first of all examples of modern art, is the best 
engraving I could find of the picture which, founded on that idea of Christ's being the Giver of Light, contains, I believe, the most true and useful piece of religious vision which realistic art has yet embodied. But why is the metaphor so necessary, or, rather, how far is it a metaphor at all? Do you think the words 'Light of the World' mean only 'Teacher or Guide of the World'? When the Sun of Justice is said to rise with health in its wings, do you suppose the image only means the correction of error? Or does it even mean so much? The Light of Heaven is needed to do that perfectly. But what we are to pray for is the Light of the World; nay, the Light "that lighteth every man that cometh into the world."

I I6. You will find that it is no metaphornor has it ever been so.

To the Persian, the Greek, and the Christian, the sense of the power of the God of Light has been one and the same. That power is not merely in teaching or protecting, but in the enforcement of purity of body, and of equity or justice in the heart; and this, observe, not heavenly purity, nor final justice ; but, now, and here, actual purity in the midst of the world's 
foulness, - practical justice in the midst of the world's iniquity. And the physical strength of the organ of sight, - the physical purity of the flesh, the actual love of sweet light and stainless colour,--are the necessary signs, real, inevitable, and visible, of the prevailing presence, with any nation, or in any house, of the "Light that lighteth every man that cometh into the w orld."

I 17. Physical purity;-actual love of sweet light, and of fair colour. This is one palpable sign, and an entirely needful one, that we have got what we pretend to pray for every morning. That, you will find, is the meaning of Apollo's war with the Python-of your own St. George's war with the dragon. You have got that battle stamped again on every sovereign in your pockets, but do you think the sovereigns are helping, at this instant, St. George in his battle? Once, on your gold of the Henrys' times, you had St. Michael and the dragon, and called your coins 'angels.' How much have they done lately, of angelic work, think you, in purifying the earth?

I I 8. Purifying, literally, purging and cleansing. That is the first "sacred art" all men have to learn. And the words I deferred to 
the close of this lecture, about the proposed improvements in Oxford, are very few. Oxford is, indeed, capable of much improvement, but only by undoing the greater part of what has been done to it within the last twenty years; and, at present, the one thing that I would say to well-meaning persons is, 'For Heaven's sake -literally for Heaven's sake-let the place alone, and clean it.' I walked last week to Iffley-not having been there for thirty years. I did not know the church inside; I found it pitch-dark with painted glass of barbarous manufacture, and the old woman who showed it infinitely proud of letting me in at the front door instead of the side one. But close by it, not fifty yards down the hill, there was a little well-a holy well it should have been; beautiful in the recess of it, and the lovely ivy and weeds above it, had it but been cared for in a human way; but so full of frogs that you could not have dipped a cup in it without catching one.

What is the use of pretty painted glass in your churches when you have the plagues of Egypt outside of them ?

I I9. I walked back from Iffley to Oxford by 
what was once the most beautiful approach to an academical city of any in Europe. Now it is a wilderness of obscure and base buildings. You think it a fine thing to go into Iffley church by the front door;- - and you build cheap lodginghouses over all the approach to the chief university of English literature! That, forsooth, is your luminous cloister, and porch of Polygnotus to your temple of Apollo. And in the centre of that temple, at the very foot of the dome of the Radclyffe, between two principal colleges, the lane by which I walked from my own college half an hour ago, to this place,-Brasen-nose Laneis left in a state as loathsome as a back-alley in the East end of London.

I 20. These, I suppose, are the signs of extending liberality, and disseminated advantages of education.

Gentlemen, if, as was lately said by a leading member of your Government, the function of a university be only to examine, it may indeed examine the whole mob of England in the midst of a dunghill ; but it cannot teach the gentlemen of England in the midst of a dunghill; no, nor even the people of England. How many of her people it ought to teach is a question. We think, 
now-a-days, our philosophy is to light every man that cometh into the world, and to light every man equally. Well, when indeed you give up all other commerce in this island, and, as in Bacon's "New Atlantis," only buy and sell to get God's first creature, which was light, there may be some equality of gain for us in that possession. But until then,-and we are very far from such a time-the light cannot be given to all men equally. Nay, it is becoming questionable whether, instead of being equally distributed to all, it may not be equally withdrawn from us all : whether the ideas of purity and justice,- - of loveliness which is to sanctify our peace,-and of justice which is to sanctify our battle, are not vanishing from the purpose of our policy, and even from the conception of our education.

The uses, and the desire, of seclusion, of meditation, of restraint, and of correction-are they not passing from us in the collision of worldly interests, and restless contests of mean hope, and meaner fear? What light, what health, what peace, or what security,-youths of Englanddo you come here now to seek? In what sense do you receive-with what sincerity do you adopt for yourselves-the ancient legend of your 
schools, "Dominus illuminatio mea, et salus mea; quem timebo"?

I2I. Remember that the ancient theory on which this university was founded, - not the theory of any one founder, observe, nor even the concluded or expressed issue of the wisdom of many; but the tacit feeling by which the work and hope of all were united and completed---was, that England should gather from among her children a certain number of purest and best, whom she might train to become, each in their day of strength, her teachers and patterns in religion, her declarers and doers of justice in law and her leaders in battle. Bred, it might be, by their parents, in the fond poverty of learning, or amidst the traditions and discipline of illustrious houses,-in either manner separate, from their youth up, to their glorious offices-they came here to be kindled into the lights that were to be set on the hills of England, brightest of the pious, the loyal, and the brave. Whatever corruption blighted, whatever worldliness buried, whatever sin polluted their endeavour, this conception of its meaning remained; and was indeed so fulfilled in faithfulness, that to the men whose passions were tempered, and whose 
hearts confirmed, in the calm of these holy places, you, now living, owe all that is left to you of hope in heaven, and all of safety or honour that you have to trust and defend on earth.

Their children have forfeited, some by guilt, and many in folly, the leadership they inherited; and every man in England now is to do and to learn what is right in his own eyes. How much need, therefore, that we should learn first of all what eyes are; and what vision they ought to possess-science of sight granted only to clearness of soul; but granted in its fulness even to mortal eyes: for though, after the skin, worms may destroy their body, happy the pure in heart, for they, yet in their flesh, shall see the Light of Heaven, and know the will of God. 


\section{LECTURE VII.}

THE RELATION TO ART OF THE SCIENCES OF INORGANIC FORM.

February 9th, 1872.

I22. I DID not wish in my last lecture, after I had directed your attention to the special bearing of some of the principles I pleaded for, to enforce upon you any farther general conclusions. But it is necessary now to collect the gist of what I endeavoured to show you respecting the organs of sight ; namely, that in proportion to the physical perfectness or clearness of them is the degree in which they are raised from the perception of prey to the perception of beauty and of affection. The imperfect and brutal instrument of the eye may be vivid with malignity, or wild with hunger, or manifoldly detective with microscopic exaggeration, assisting theingenuity of insects with a multiplied and permanent monstrosity of all things round them; but the noble 
human sight, careless of prey, disdainful of minuteness, and reluctant to anger, becomes clear in gentleness, proud in reverence, and joyful in love. And finally, the physical splendour of light and colour, so far from being the perception of a mechanical force by a mechanical instrument, is an entirely spiritual consciousness, accurately and absolutely proportioned to the purity of the moral nature, and to the force of its natural and wise affections.

I23. That was the sum of what I wished to show you in my last lecture ; and observe, that what remains to me doubtful in these things,and it is much--I do not trouble you with. Only what I know that on experiment you can ascertain for yourselves, I tell you, and illustrate, for the time, as well as I can. Experiments in art are difficult, and take years to try ; you may at first fail in them, as you might in a chemical analysis; but in all the matters which in this place I shall urge on your attention I can assure you of the final results.

That, then, being the sum of what I could tell you with certainty respecting the methods of sight, I have next to assure you that this faculty of sight, disciplined and pure, is the only proper 
faculty which the graphic artist is to use in his inquiries into nature. His office is to show her appearances; his duty is to know them. It is not his duty, though it may be sometimes for his convenience, while it is always at his peril, that he knows more;-knows the causes of appearances, or the essence of the things that produce them.

I 24. Once again, therefore, I must limit my application of the word science with respect to art. I told you that I did not mean by 'science' such knowledge as that triangles on equal bases and between parallels are equal, but such knowledge as that the stars in Cassiopeia are in the form of a $W$. But, farther still, it is not to be considered as science, for an artist, that they are stars at all. What he has to know is that they are luminous points which twinkle in a certain manner, and are pale yellow, or deep yellow, and may be quite deceptively imitated at a certain distance by brass-headed nails. This he ought to know, and to remember accurately, and his art knowledge-the science, that is to say-of which his art is to be the reflection, is the sum of knowledges of this sort; his memory of the look of the sun and moon at such and such times, 
through such and such clouds; his memory of the look of the mountains,-of the look of sea, - of the look of human faces.

125. Perhaps you would not call that 'science' at all. It is no matter what either you or I call it. It $i$ s science of a certain order of facts. Two summers ago, looking from Verona at sunset, I saw the mountains beyond the Lago di Garda of a strange blue, vivid and rich like the bloom of a damson. I never saw a mountain-blue of that particular quality before or since. My science as an artist consists in my knowing that sort of blue from every other sort, and in my perfect recollection that this particular blue had such and such a green associated with it in the near fields. I have nothing whatever to do with the atmospheric causes of the colour: that knowledge would merely occupy my brains wastefully, and warp my artistic attention and energy from their point. Or to take a simpler instance yet : Turner, in his early life, was sometimes good-natured, and would show people what he was about. $\mathrm{He}$ was one day making a drawing of Plymouth harbour, with some ships at the distance of a mile or two, seen against the light. Having shown this drawing to a naval officer, the naval 
officer observed with surprise, and objected with very justifiable indignation, that the ships of the line had no port-holes. "No," said Turner, "certainly not. If you will walk up to Mount Edgecumbe, and look at the ships against the sunset, you will find you can't see theport-holes." "Well, but," said the navalofficer, still indignant, "you know the port-holes are there." "Yes," said Turner, "I know that well enough; but my business is to draw what I see, and not what I know is there."

I26. Now, that is the law of all fine artistic work whatsoever; and, more than that, it is, on the whole, perilous to you, and undesirable, that you should know what is there. If, indeed, you have so perfectly-disciplined your sight that it cannot be influenced by prejudice;-if you are sure that none of your knowledge of what is there will be allowed to assert itself; and that you can reflect the ship as simply as the sea beneath it does, though you may know it with the intelligence of a sailor,-then, indeed, you may allow yourself the pleasure, and what will sometimes be the safeguard from error, of learning what ships or stars, or mountains, are in reality; but the ordinary powers of human 
perception are almost certain to be disturbed by the knowledge of the real nature of what they draw : and, until you are quite fearless of your faithfulness to the appearances of things, the less you know of their reality the better.

127. And it is precisely in this passive and naïve simplicity that art becomes, not only greatest in herself, but most useful to science. If she knew anything of what she was representing, she would exhibit that partial knowledge with complacency; and miss the points beside it, and beyond it. Two painters draw the same mountain; the one has got unluckily into his head some curiosity about glacier marking; and the other has a theory of cleavage. The one will scratch his mountain all over; - the other split it to pieces; and both drawings will be equally useless for the purposes of honest science.

128. Any of you who chance to know my books cannot but be surprised at my saying these things; for, of all writers on art, I suppose there is no one who appeals so often as I do to physical science. But observe, I appeal as a critic of art, never as a master of it. Turner made drawings of mountains and clouds which the public said were absurd. I said, on the contrary, they 
were the only true drawings of mountains and clouds ever made yet: and I proved this to be so, as only it could be proved, by steady test of physical science: but Turner had drawn his mountains rightly, long before their structure was known to any geologist in Europe; and has painted perfectly truths of anatomy in clouds which I challenge any meteorologist in Europe to explain at this day.

I29. And indeed I was obliged to leave "Modern Painters" incomplete, or, rather, as a mere sketch of intention, in analysis of the forms of cloud and wave, because I had not scientific data enough to appeal to. Just reflect for an instant how absolutely whatever has been done in art to represent these most familiar, yet most spectral forms of cloud-utterly inorganic, yet, by spiritual ordinance, in their kindness fair, and in their anger frightful,-how all that has yet been done to represent them, from the undulating bands of blue and white which give to heraldry its nebule bearing, to the finished and deceptive skies of Turner, has been done without one syllable of help from the lips of science.*

* Rubens' rainbow, in the Loan Exhibition this year, was of dull blue, darker than the sky, in a scene lighted from the 
130. The rain which flooded our fields the Sunday before last, was followed, as you will remember, by bright days, of which Tuesday the 2oth was, in London, notable for the splendour, towards the afternoon, of its white cumulus clouds. There has been so much black east wind lately, and so much fog and artificial gloom, besides, that I find it is actually some two years since I last saw a noble cumulus cloud under full light. I chanced to be standing under the Victoria Tower at Westminster, when thelargest mass of them floated past, that day, from the north-west; and I was more impressed than ever yet by the awfulness of the cloud-form, and its unaccountableness, in the present state of our knowledge. The Victoria Tower, seen against it, had no magnitude : it was like looking at Mont Blanc over a lamp-post. The domes of cloudsnow were heaped as definitely; their broken flanks were as grey and firm as rocks, and the

side of the rainbow. Rubens is not to be blamed for ignorance of optics, but for never having so much as looked at a rainbow carefully: and I do not believe that my friend Mr. Alfred Hunt, whose study of rainbow, in the rooms of the Water Colour Society last year, was unrivalled, for vividness and truth, by any I know, learned how to paint it by studying optics. 
whole mountain, of a compass and height in heaven which only became more and more inconceivable as the eye strove to ascend it, was passing behind the tower with a steady march, whose swiftness must in reality have been that of a tempest : yet, along all the ravines of vapour, precipice kept pace with precipice, and not one thrust another.

I 3 I. What is it that hews them out? Why is the blue sky pure there,-cloud solid here; and edged like marble: and why does the state of the blue sky pass into the state of cloud, in that calm advance?

It is true that you can more or less imitate the forms of cloud with explosive vapour or steam; but the steam melts instantly, and the explosive vapour dissipates itself. The cloud, of perfect form, proceeds unchanged. It is not an explosion, but an enduring and advancing presence. The more you think of it, the less explicable it will become to you.

132. That this should yet be unexplained in the kingdom of the air is, however, no marvel, since aspects of a similar kind are unexplained in the earth, which we tread, and in the water which we drink and wash with. - You seldom 
pass a day without receiving some pleasure from the cloudings in marble; can you explain how the stone was clouded? You certainly do not pass a day without washing your hands. Can you explain the frame of a soap-bubble?

I33. I have allowed myself, by way of showing at once what I wanted to come to, to overlook the proper arrangement of my subject, and I must draw back a little.

For all his own purposes, merely graphic, we say, if an artist's eye is fine and faithful, the fewer points of science he has in his head, the better. But for purposes more than graphic, in order that he may feel towards things as he should, and choose them as we should, he ought to know something about them; and if he is quite sure that he can receive the science of them without letting himself become uncandid and narrow in observation, it is very desirable that he should be acquainted with a little of the alphabet of structure,-just as much as may quicken and certify his observation, without prejudicing it. Cautiously, therefore, and receiving it as a perilous indulgence, he may venture to learn, perhaps as much astronomy as may prevent his carelessly putting the new moon 
wrong side upwards; and as much botany as will prevent him from confusing, which I am sorry to say Turner did, too often, Scotch firs with stone pines. He may concede so much to geology as to choose, of two equally picturesque views, one that illustrates rather than conceals the structure of a crag : and perhaps, once or twice in his life, a portrait painter might advantageously observe how unlike a skull is to a face. And for you, who are to use your drawing as one element in general education, it is desirable that physical science should assist in the attainment of truth which a real painter seizes by practice of eye.

I34. For this purpose I shall appeal to your masters in science to furnish us, as they have leisure, with some simple and readable accounts of the structure of things which we have to draw continually. Such scientific accounts will not usually much help us to draw them, but will make the drawing, when done, far more valuable to us.

I have told you, for instance, that nobodyat least, no painter-can at present explain the structure of a bubble. To know that structure will not help you to draw sea-foam, but it will 
VII. SCIENCES OF INORGANIC FORM.

make you look at sea-foam with greater interest.

I am not able now to watch the course of modern science, and may perhaps be in error in thinking that the frame of a bubble is still unexplained. But I have not yet met, by any chance, with an account of the forces which, under concussion, arrange the particles of a fluid into a globular film; though, from what I know of cohesion, gravity, and the nature of the atmosphere, I can make some shift to guess at the kind of action that takes place in forming a single bubble. But how one bubble absorbs another without breaking it ; or what exact methods of tension prepare for the change of form, and establish it in an instant, I am utterly at a loss to conceive.

Here, I think, then, is one familiar matter which up to the possible point, science might condescendingly interpret for us. The exhaustion of the film in preparation for its change: the determination of the smaller bubble to yield itself up to the larger; the instantaneous flash into the new shape, and the swift adjustment of the rectangular lines of intersection in the marvellous vaulting -all this I want to be explained 
to us, so that, if we cannot understand it altogether, we may at least know exactly how far we do, and how far we do not.

I35. And, next to the laws of the formation of a bubble, I want to see, in simple statement, those of the formation of a bottle. Namely, the laws of its resistance to fracture, from without and within, by concussion or explosion; and the due relations of form to thickness of material ; so that, putting the problem in a constant form, we may know, out of a given quantity of material, how to make the strongest bottle under given limitations as to shape. For instance,you have so much glass given you : your bottle is to hold two pints, to be flat-bottomed, and so narrow and long in the neck that you can grasp it with your hand. What will be its best ultimate form ?

I 36. Probably, if you thought it courteous, you would laugh at me just now; and, at any rate, are thinking to yourselves that this art problem at least needs no scientific investigation, having been practically solved, long ago, by the imperative human instinct for the preservation of bottled stout. But you are only feeling now, gentlemen, and recognizing in one instance, 
VII. SCIENCES OF INORGANIC FORM. I5 I

what I tell you of all. Every scientific investigation is, in the same sense as this would be, useless to the trained master of any art. To the soap-bubble blower, and glass-blower,-to the pot-maker and bottle-maker,-if dexterous craftsmen, your science is of no account; and the imp of their art may be imagined as always looking triumphantly and contemptuously, out of its successfully-produced bottle, on the vain analysis of centrifugal impulse and inflating breath.

I 37. Nevertheless, in the present confusion of instinct and opinion as to beautiful form, it is desirable to have these two questions more accurately dealt with. For observe what they branch into. The coloured segments of globe out of which foam is constituted, are portions of spherical vaults constructed of fluent particles. You cannot have the principles of spherical vaulting put in more abstract terms.

Then considering the arch as the section of a vault, the greater number of Gothic arches may be regarded as the intersections of two spherical vaults.

Simple Gothic foliation is merely the triple, quadruple, or variously multiple repetition of such intersection. 
And the beauty-(observe this carefully)the beauty of Gotlijc arches, and of their foliation, always involves reference to the strength of their structure ; but only to their structure as self-sustaining; not as sustaining superincumbent weight. In the most literal of senses, "the earth hath bubbles as the water hath; and these are of them."

I 38. What do you think made Michael Angelo look back to the dome of Santa Maria del Fiore, saying, "Like thee I will not build one, better than thee I cannot" ? To you or to me there is nothing in that dome different from hundreds of others. Which of you, who have been at Florence, can tell me honestly he saw anything wonderful in it? But Michael Angelo knew the exact proportion of thickness to weight and curvature which enabled it to stand as securely as a mountain of adamant, though it was only a film of clay, as frail, in proportion to its bulk, as a sea shell. Over the massy war towers of the city it floated; fragile, yet without fear. "Better than thee I cannot."

I 39. Then think what the investigation of the bottle branches into, joined with that of its necessary companion, the cup. There is a sketch for 


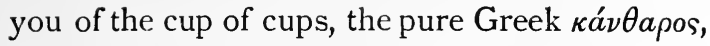
which is always in the hand of Dionusos, as the thunderbolt is in that of Zeus. Learn but to draw that thoroughly, and you won't have much more to learn of abstract form; for the investigation of the kinds of line that limit this will lead you into all the practical geometry of nature; the ellipses of her sea-bays in perspective; the parabolas of her waterfalls and fountains in profile; the catenary curves of their falling festoons in front; the infinite variety of accelerated or retarded curvature in every condition of mountain débris. But do you think mere science can measure for you any of these things? That book on the table is one of the four volumes of Sir William Hamilton's “Greek Vases." He has measured every important vase vertically and horizontally, with precision altogether admirable, and which may, I hope, induce you to have patience with me in the much less complex, though even more scrupulous, measurements which I shall require on my own examples. Yet English pottery remains precisely where it was, in spite of all this investigation. Do you fancy a Greek workman ever made a vase by measurement? He dashed it from his hand on 
the wheel, and it was beautiful: and a Venetian glass-blower swept you a curve of crystal from the end of his pipe; and Reynolds or Tintoret swept you a curve of colour from their pencils, as a musician the cadence of a note, unerring, and to be measured, if you please, afterwards, with the exactitude of Divine law.

140. But, if the truth and beauty of art are thus beyond attainment by help of science, how much more its invention? I must defer what I have chiefly to say on this head till next lecture ; but to-day I can illustrate, simply, the position of invention with respect to science in one very important group of inorganic forms-those of drapery.

141. If you throw at random over a rod a piece of drapery of any material which will fall into graceful folds, you will get a series of sinuous folds in catenary curves: and any given disposition of these will be nearly as agreeable as any other; though, if you throw the stuff on the rod a thousand times, it will not fall twice alike.

I42. But suppose, instead of a straight rod, you take a beautiful nude statue, and throw the piece of linen over that. You may encumber and conceal its form altogether; you may entirely 
conceal portions of the limbs, and show others ; or you may leave indications, under the thin veil, of the contours which are hidden ; but in ninetynine cases out of a hundred you will wish the drapery taken off again; you will feel that the folds are in some sort discrepant and harmful, and eagerly snatch them away. However passive the material, however softly accommodated to the limbs, the wrinklings will always look foreign to the form, like the drip of a heavy shower of rain falling off it, and will load themselves in the hollows uncomfortably. You will have to pull them about; to stretch them one way, loosen them in another, and supply the quantity of government which a living person would have given to the dress, before it becomes at all pleasing to you.

I43. Doing your best, you will still not succeed to your mind, provided you have, indeed, a mind worth pleasing. No adjustment that you can make, on the quiet figure, will give any approximation to the look of drapery which has previously accommodated itself to the action which brought the figure into the position in which it stays. On a really living person, gracefully dressed, and who has paused from graceful 
motion, you will get, again and again, arrangements of fold which you can admire: but they will not remain to be copied, the first following movement alters all. If you had your photographic plate ready and could photograph-I don't know if it has been tried-girls, like waves, as they move, you would get what was indeed lovely; and yet, when you compared even such results with fine sculpture, you would see that there was something wanting;-that, in the deepest sense, all was yet wanting.

I44. Yet this is the most that the plurality of artists can do, or think of doing. They draw the nude figure with careful anatomy; they put their model or their lay figure into the required position; they arrange draperies on it to their mind, and paint them from the reality. All such work is absolutely valueless,- - worse than valueless in the end of it, blinding us to the qualities of fine work.

In true design it is in this matter of drapery as in all else. There is not a fold too much, and all that are given aid the expression, whether of movement or character. Here is a bit of Greek sculpture, with many folds; here is a bit of Christian sculpture with few. From the many, 
not one could be removed without harm, and to the few, not one could be added. This alone is art, and no science will ever enable you to do this, but the poetic and fabric instincts only.

145. Nevertheless, however far above science, your work must comply with all the requirements of science. The first thing you have to ask is, Is it scientifically right? That is still nothing, but it is essential. In modern imitations of Gothic work the artists think it religious to be wrong, and that Heaven will be propitious only to saints whose stoles or petticoats stand or fall into incredible angles.

All that nonsense I will soon get well out of your heads by enabling you to make accurate studies from real drapery, so that you may be able to detect in a moment whether the folds in any design are natural and true to the form, or artificial and ridiculous.

I46. But this, which is the science of drapery, will never do more than guard you in your first attempts in the art of it. Nay, when once you have mastered the elements of such science, the most sickening of all work to you will be that in which the draperies are all right,---and nothing else is. In the present state of our schools one 
of the chief mean merits against which I shall have to warn you is the imitation of what milliners admire: nay, in many a piece of the best art I shall have to show you that the draperies are, to some extent, intentionally ill-done, lest you should look at them. Yet, through every complexity of desirableness, and counter-peril, hold to the constant and simple law I have always given you-that the best work must be right in the beginning, and lovely in the end.

147. Finally, observe that what is true respecting these simple forms of drapery is true of all other inorganic form. It must become organic under the artist's hand by his invention. As there must not be a fold in a vestment too few or too many, there must not, in noble landscape, be a fold in a mountain, too few or too many. As you will never get from real linen cloth, by copying it ever so faithfully, the drapery of a noble statue, so you will never get from real mountains, copy them never so faithfully, the forms of noble landscape. Anything more beautiful than the photographs of the Valley of Chamouni, now in your print-sellers' windows, cannot be conceived. For geographical and geological purposes they are worth 
anything ; for art purposes, worth-a good deal less than zero. You may learn much from them, and will mislearn more. But in Turner's "Valley of Chamouni" the mountains have not a fold too much, nor too little. There are no such mountains at Chamouni : they are the ghosts of eternal mountains, such as have been, and shall be, for evermore.

148. So now in sum, for I may have confused you by illustration,-

I. You are, in drawing, to try only to represent the appearances of things, never what you know the things to be.

II. Those appearances you are to test by the appliance of the scientific laws relating to aspect; and to learn, by accurate measurement, and the most fixed attention, to represent with absolute fidelity.

III. Having learned to represent actual appearances faithfully, if you have any human faculty of your own, visionary appearances will take place to you which will be nobler and more true than any actual or material appearances; and the realization of these is the function of every fine art, which is founded absolutely, 
therefore, in truth, and consists absolutely in imagination. And once more we may conclude with, but now using them in a deeper sense, the words of our master-" The best in this kind are but shadows."

It is to be our task, gentlemen, to endeavour that they may be at least so much. 


\section{LECTURE VIII.}

THE RELATION TO ART OF THE SCIENCES

OF ORGANIC FORM.

\section{March 2nd, I872.}

I49. I HAVE next in order to speak of the relation of art to science, in dealing with its own principal subject-organic form, as the expression of life. And, as in my former lecture, I will tell you at once what I wish chiefly to enforce upon you.

First,-but this I shall have no time to dwell upon,-That the true power of art must be founded on a general knowledge of organic nature, not of the human frame only.

Secondly.-That in representing this organic nature, quite as much as in representing inanimate things, Art has nothing to do with structures, causes, or absolute facts; but only with appearances.

Thirdly.-That in representing these appearances, she is more hindered than helped by the 
knowledge of things which do not externally appear; and therefore, that the study of anatomy generally, whether of plants, animals, or man, is an impediment to graphic art.

Fourthly. - That especially in the treatment and conception of the human form, the habit of contemplating its anatomical structure is not only a hindrance, but a degradation ; and farther yet, that even the study of the external form of the human body, more exposed than it may be healthily and decently in daily life, has been cssentially destructive to every school of art in which it has been practised.

I50. These four statements I undertake, in the course of our future study, gradually to confirm to you. In a single lecture I, of course, have time to do little more than clearly state and explain them.

First, I tell you that art should take cognizance of all living things, and know them, so as to be able to name, that is to say, in the truest distinctive way, to describe them. The Creator daily brings, before the noblest of His creatures, every lower creature, that whatsoever Man calls it, may be the name thereof.

Secondly.--In representing, nay, in thinking 
VIII. SCIENCES OF ORGANIC FORM.

of, and caring for, these beasts, man has to think of them essentially with their skins on them, and with their souls in them. He is to know how they are spotted, wrinkled, furred, and feathered: and what the look of them is, in the eyes ; and what grasp, or cling, or trot, or pat, in their paws and claws. He is to take every sort of view of them, in fact, except one,- the Butcher's view. He is never to think of them as bones and meat.

Thirdly.-In the representation of their appearance, the knowledge of bones and meat, of joint and muscle, is more a hindrance than a help.

Lastly.-With regard to the human form, such knowledge is a degradation as well as a hindrance; and even the study of the nude is injurious, beyond the limits of honour and decency in daily life.

Those are my four positions. I will not detain you by dwelling on the first two- that we should know every sort of beast: and know it with its skin on it, and its soul within it. What you feel to be a paradox-perhaps you think an incredible and insolent paradox-is my telling you that you will be hindered from doing this by the 
study of anatomy. I address myself, therefore, only to the last two points.

I 5 I. Among your standard engravings, I have put that of the picture by Titian, in the Strozzi Palace, of a little Strozzi maiden feeding her dog. I am going to put in the Rudimentary Series, where you can always get at it (R. I25), this much more delightful, though not in all points standard, picture by Reynolds, of an infant daughter of George the Third's, with her Skye terrier.

I have no doubt these dogs are the authentic pets, given in as true portraiture as their mistresses ; and that the little Princess of Florence and Princess of England were both shown in the company which, at that age, they best liked ;the elder feeding her favourite, and the baby with her arms about the neck of hers.

But the custom of putting either the dog, or some inferior animal, to be either in contrast, or modest companionship, with the nobleness of human form and thought, is a piece of what may be called mental comparative anatomy, which has its beginning very far back in art indeed. One of quite the most interesting Greek vases in the British Museum is that of which the painting 
VIII. SCIENCES OF ORGANIC FORM.

long went under the title of "Anacreon and his Dog." It is a Greek lyric poet, singing with lifted head, in the action given to Orpheus and Philammon in their moments of highest inspiration; while, entirely unaffected by and superior to the music, there walks beside him a sharpnosed and curly-tailed dog, painted in what the exclusive admirers of Greek art would, I suppose, call an ideal manner; that is to say, his tail is more like a display of fireworks than a tail ; but the ideal evidently founded on the material existence of a charming, though supercilious, animal not unlike the one which is at present the chief solace of my labours in Oxford, Dr. Acland's dog Bustle. I might go much farther back than this; but at all events, from the time of the golden dog of Pandareos, the fawn of Diana, and the eagle, owl, and peacock of the great Greek gods, you find a succession of animal types-centralized in the Middle Ages, of course, by the hound and the falcon-used in art either to symbolize, or contrast with, dignity in human persons. In modern portraiture, the custom has become vulgarized by the anxiety of everybody who sends their picture, or their children's, to the Royal Academy, to have it 
demonstrated to the public by the exhibition of a pony, and a dog with a whip in its mouth, that they live, at the proper season, in a country house. But by the greater masters the thing is done always with a deep sense of the mystery of the comparative existences of living creatures, and of the methods of vice and virtue exhibited by them. Albert Dürer scarcely ever draws a scene in the life of the Virgin, without putting into the foreground some idle cherubs at play with rabbits or kittens; and sometimes lets his love of the grotesque get entirely the better of him, as in the engraving of the Madonna with the monkey. Veronese disturbs the interview of the queen of Sheba with Solomon, by the petulance of the queen of Sheba's Blenheim spaniel, whom Solomon had not treated with sufficient respect; and when Veronese is introduced himself, with all his family, to the Madonna, I am sorry to say that his own pet dog turns its back to the Madonna, and walks out of the room.

I52. But among all these symbolic playfulnesses of the higher masters, there is not one more perfect than this study by Reynolds of the infant English Princess with her wire-haired 
VIII. SCIENCES OF ORGANIC FORM.

terrier. He has put out his whole strength to show the infinite differences, yet the blessed harmonies, between the human and the lower nature. First, having a blue-eyed, , soft baby to paint, he gives its full face, as round as may be, and rounds its eyes to complete openness, because somebody is coming whom it does not know. But it opens its eyes in quiet wonder, and is not disturbed, but behaves as a princess should. Beside this soft, serenely-minded baby, Reynolds has put the roughest and roughestminded dog he could think of. Instead of the full round eyes, you have only the dark places in the hair where you know the terrier's eyes must be-sharp enough, if you could see them -and very certainly seeing you, but not at all wondering at you, like the baby's. For the terrier has instantly made up his mind about you; and above all, that you have no business there; and is growling and snarling in his fiercest manner, though without moving from his mistress's side, or from under her arm. You have thus the full contrast between the grace and true charm of the child, who "thinketh no

* I have not seen the picture: in the engraving the tint of the eyes would properly represent grey or blue. 
evil" of you, and the uncharitable narrowness of nature in the grown-up dog of the world, who thinks nothing but evil of you. But the dog's virtue and faithfulness are not told less clearly; the baby evidently uses the creature just as much for a pillow as a playmate;-buries its arm in the rough hair of it with a loving confidence, half already converting itself to protection: and baby will take care of dog, and dog of baby, through all chances of time and fortune.

I 53. Now the exquisiteness with which the painter has applied all his skill in composition, all his dexterity in touch of pencil, and all his experience of the sources of expression, to complete the rendering of his comparison, cannot, in any of the finest subtleties of it, be explained; but the first steps of its science may be easily traced; and with little pains you may see how a simple and large mass of white is opposed to a rugged one of grey; how the child's face is put in front light, that no shadow may detract from the brightness which makes her, as in Arabian legends, "a princess like to the full moon"-how, in this halo, the lips and eyes are brought out in deep and rich colour, while 
scarcely a gleam of reflection is allowed to disturb the quietness of the eyes;-(the terrier's, you feel, would glitter enough, if you could see them, and flash back in shallow fire; but the princess's eyes are thinking, and do not flash;) -how the quaint cap surrounds, with its not wholly painless formalism, the courtly and patient face, opposed to the rugged and undressed wild one; and how the easy grace of soft limb and rounded neck is cast, in repose, against the uneasily gathered up crouching of the short legs, and petulant shrug of the eager shoulders, in the ignobler creature.

I 54. Now, in his doing of all this, Sir Joshua was thinking of, and seeing, whatever was best in the creatures, within and without. Whatever was most perfectly doggish-perfectly childish -in soul and body. The absolute truth of outer aspect, and of inner mind, he seizes infallibly; but there is one part of the creatures which he never, for an instant, thinks of, or cares for,their bones. Do you suppose that, from first to last, in painting such a picture, it would ever enter Sir Joshua's mind to think what a dog's skull would look like, beside a baby's? The quite essential facts to him are those of which 
the skull gives no information-that the baby has a flattish pink nose, and the dog a bossy black one. You might dissect all the dead dogs in the water supply of London without finding out, what, as a painter, it is here your only business precisely to know, - what sort of shininess there is on the end of a terrier's nose ; and for the position and action of the creatures, all the four doctors together, who set Bustle's leg for him the other day, when he jumped out of a two-pair-of-stairs window to bark at the volunteers, could not have told Sir Joshua how to make his crouching terrier look ready to snap, nor how to throw the child's arm over its neck in complete, yet not languid, rest.

I 55. Sir Joshua, then, does not think of, or care for, anatomy, in this picture; but if he had, would it have done him harm? You may easily see that the child's limbs are not drawn with the precision that Mantegna, Dürer, or Michael Angelo would have given them. Would some of their science not have bettered the picture?

I can show you exactly the sort of influence their science would have had.

In your Rudimentary Series, I have placed in sequence two of Dürer's most celebrated 
plates (R. 65, R. 66), the coat of arms with the skull, and the Madonna crowned by angels; and that you may see precisely what qualities are, and are not, in this last, I have enlarged the head by photography, and placed it in your Reference Series (II7). You will find the skull is perfectly understood, and exquisitely engraved, but the face, imperfectly understood and coarsely engraved. No man who has studied the skull as carefully as Dürer did, ever could engrave a face beautifully, for the perception of the bones continually thrusts itself upon him in wrong places, and in trying to conquer or modify it, he distorts the flesh. Where the features are marked, and full of character, he can quit himself of the impression; but in the rounded contour of women's faces he is always forced to think of the skull; and even in his ordinary work often draws more of bones and hair, than face.

I 56. I could easily give you more definite, but very disagreeable, proofs of the evil of knowing the anatomy of the human face too intimately : but will rather give you further evidence by examining the skull and face of the creature who has taught us so much already, - - the eagle. 
Here is a slight sketch of the skull of the golden eagle. It may be interesting to you sometimes to make such drawings roughly for the sake of the points of mechanical arrangementas here in the circular bones of the eye-socket ; but don't suppose that drawing these a million of times over will ever help you in the least to draw an eagle itself. On the contrary, it would almost to a certainty hinder you from noticing the essential point in an eagle's head-the projection of the brow. All the main work of the eagle's eye is, as we saw, in looking down. To keep the sunshine above from teasing it, the eye is put under a triangular penthouse, which is precisely the most characteristic thing in the bird's whole aspect. Its hooked beak does not materially distinguish it from a cockatoo, but its hooded eye does. But that projection is not accounted for in the skull; and so little does the anatomist care about it, that you may hunt through the best modern works on ornithology, and you will find eagles drawn with all manner of dissections of skulls, claws, clavicles, sternums, and gizzards; but you won't find so much as one poor falcon drawn with a falcon's eye. 
VIII. SCIENCES OF ORGANIC FORM.

I 57. But there is another quite essential fcint $\mathrm{i}^{\mathrm{n}}$ an eagle's head, in comprehending which, again, the skull will not help us. The skull in the human creature fails in three essential points. It is eyeless, noseless, and lipless. It fails only in an eagle in the two points of eye and lip ; for an eagle has no nose worth mentioning ; his beak is only a prolongation of his jaws. But he has lips very much worth mentioning, and of which his skull gives no account. One misses them much from a human skull :- "Here hung those lips that I have kissed, I know not how oft,"-but from an eagle's you miss them more, for he is distinct from other birds in having with his own eagle's eye, a dog's lips, or very nearly such; an entirely fleshy and ringent mouth, bluish pink, with a perpetual grin upon it.

So that if you look, not at his skull, but at him, attentively enough, you will precisely get Eschylus's notion of him, essential in the Greek

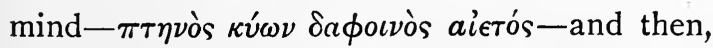
if you want to see the use of his beak or bill, as distinguished from a dog's teeth, take a drawing from the falconry of the Middle Ages, and you will see how a piece of flesh becomes

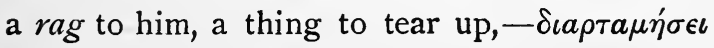




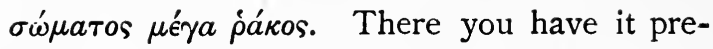
cisely, in a falcon I got out of Mr. Coxe's favourite fourteenth century missal.

Now look through your natural history books from end to end ; see if you can find one drawing, with all their anatomy, which shows you either the eagle's eye, his lips, or this essential use of his beak, so as to enable you thoroughly to understand those two lines of Eschylus: then, look at this Greek eagle on a coin of Elis, R. 50, and this Pisan one, in marble, Edu. I 3 I, and you will not doubt any more that it is better to look at the living birds, than to cut them to pieces.

I 58. Anatomy, then,-I will assume that you grant, for the moment, as I will assiriedly prove to you eventually, - will not help us to draw the true appearances of things. But may it not add to our intelligent conception of their nature?

So far from doing this, the anatomical study which has, to our much degradation and misfortune, usurped the place, and taken the name, at once of art and of natural history, has produced the most singularly mischievous effect on the faculty of delineation with respect to different races of animals. In all recent books on natural history, you will find the ridiculous and ugly 
VIII. SCIENCES OF ORGANIC FORM.

creatures done well, the noble and beautiful creatures done, I do not say merely ill, but in no wise. You will find the law hold universally that apes, pigs, rats, weasels, foxes, and the like, -but especially apes,-are drawn admirably; but not a stag, not a lamb, not a horse, not a lion; - the nobler the creature, the more stupidly it is always drawn, not from feebleness of art power, but a far deadlier fault than that-a total want of sympathy with the noble qualities of any creature, and a loathsome delight in their disgusting qualities. And this law is so thoroughly carried out that the great French historian of the mammalia, St. Hilaire, chooses, as his single example of the highest of the race, the most nearly bestial type he can find, human, in the world. Let no girl ever look at the book, nor any youth who is willing to take my word; let those who doubt me, look at the example he has given of womankind.

I 59. But admit that this is only French anatomy, or ill-studied anatomy, and that, rightly studied, as Dr. Acland, for instance, would teach it us, it might do us some kind of good.

I must reserve for my lectures on the school of Florence any analysis of the effect of anatomical study on European art and character; 
you will find some notice of it in my lecture on Michael Angelo; and in the course of that analysis, it will be necessary for me to withdraw the statement made in the "Stones of Venice," that anatomical science was helpful to great men, though harmful to mean ones. I am now certain that the greater the intellect, the more fatal are the forms of degradation to which it becomes liable in the course of anatomical studies; and that to Michael Angelo, of all men, the mischief was greatest, in destroying his religious passion and imagination, and leading him to make every spiritual conception subordinate to the display of his knowledge of the body. To-day, however, I only wish to give you my reasons for withdrawing anatomy from your course of study in these schools.

I60. I do so, first, simply with reference to our time, convenience, and systematic method. It has become a habit with drawing-masters to confuse this particular science of anatomy with their own art of drawing, though they confuse no other science with that art. Admit that, in order to draw a tree, you should have a knowledge of botany: Do you expect me to teach you botany here? Whatever I want you to 
know of it I shall send you to your Professor of Botany and to the Botanic Gardens, to learn. I may, perhaps, give you a rough sketch of the lines of timber in a bough, but nothing more.

So again, admit that, to draw a stone, you need a knowledge of geology. I have told you that you do not, but admit it. Do you expect me to teach you, here, the relations between quartz and oxide of iron; or between the Silurian and Permian systems? If you care about them, go to Professor Phillips, and come back to me when you know them.

And, in like manner, admit that, to draw a man, you want the knowledge of his bones :you do not; but admit that you do. Why should you expect me, here, to teach you the most difficult of all the sciences? If you want to know it, go to an hospital, and cut dead bodies to pieces till you are satisfied; then come to me, and I'll make a shift to teach you to draw, even thenthough your eyes and memory will be full of horrible things which Heaven never meant you so much as a glance at. But don't expect me to help you in that ghastly work : any more than among the furnaces and retorts in Professor Maskelyne's laboratory. 
I6I. Let us take one more step in the logical sequence. You do not, I have told you, need either chemistry, botany, geology, or anatomy, to enable you to understand art, or produce it. But there is one science which you must be acquainted with. You must very intensely and thoroughly know-how to behave. You cannot so much as feel the difference between two casts of drapery, between two tendencies of line, -how much less between dignity and baseness of gesture,-but by your own dignity of character. But, though this is an essential science, and although I cannot teach you to lay one line beside another rightly, unless you have this science, you don't expect me in these schools to teach you how to behave, if you happen not to know it before!

I62. Well, here is one reason, and a sufficiently logical one, as you will find it on consideration, for the exclusion of anatomical study from all drawing schools. But there is a more cogent reason than this for its exclusion, especially from elementary drawing-schools. It may be sometimes desirable that a student should see, as I said, how very unlike a face a skull is ; and at a leisure moment he may, without much 
harm, observe the equivocation between knees and ankles by which it is contrived that his legs, if properly made at the joints, will only bend backwards, but a crane's forwards. But that a young boy, or girl, brought up fresh to the schools of art from the country, should be set to stare, against every particle of wholesome grain in their natures, at the Elgin marbles, and to draw them with dismal application, until they imagine they like them, makes the whole youthful temper rotten with affectation, and sickly with strained and ambitious fancy. It is still worse for young persons to be compelled to endure the horror of the dissecting-room, or to be made familiar with the conditions of actual bodily form, in a climate where the restraints of dress must for ever prevent the body from being perfect in contour, or regarded with entirely simple feeling.

163. I have now, perhaps too often for your patience, told you that you must always draw for the sake of your subject-never for the sakc of your picture. What you wish to see in reality, that you should make an effort to show, in pictures and statues; what you do not wish to see in reality, you should not try to draw. 
But there is, I suppose, a very general impression on the mind of persons interested in the arts, that because nations living in cold climates are necessarily unfamiliar with the sight if the naked body, therefore, art should take it upon herself to show it them; and that they will be elevated in thought, and made more simple and grave in temper, by seeing, at least in colour and marble, what the people of the south saw in its verity.

164. I have neither time nor inclination to enter at present into discussion of the various effects, on the morality of nations, of more or less frank showing of the nude form. There is no question that if shown at all, it should be shown fearlessly, and seen constantly; but I do not care at present to debate the question : neither will I delay you by any expression of my reasons for the rule I am about to give. Trust me, I have many; and I can assert to you as a positive and perpetual law, that so much of the nude body as in the daily life of the nation may be shown with modesty, and seen' with reverence and delight,- - so much, and no more, ought to be shown by the national arts, either of painting or sculpture. What, more than 
this, either art exhibits, will, assuredly, pervert taste, and, in all probability, morals.

165. It will, assuredly, pervert taste in this essential point, that the polite ranks of the nation will come to think the living creature and its dress exempt from the highest laws of taste; and that while a man or woman must, indeed, be seen dressed or undressed with dignity, in marble, they may be dressed or undressed, if not with indignity, at least, with less than dignity, in the ball-room, and the street. Now the law of all living art is that the man and woman must be more beautiful than their pictures, and their pictures as decorous as the living man or woman; and that real dress, and gesture, and behaviour, should be more graceful than any marble or colour can effect similitude of.

166. Thus the idea of a different dress in art and reality, of which that of art is to be the ideal one, perverts taste in dress; and the study of the nude which is rarely seen, as much perverts taste in art.

Of all pieces of art that I know, skilful in execution, and not criminal in intention ;-without any exception, quite the most vulgar, and in the solemn sense of the word, most abominable, 
are the life studies which are said to be the best made in modern times, - those of Mulready, exhibited as models in the Kensington Museum.

I67. How far the study of the seldom-seen nude leads to perversion of morals, I will not, to-day, inquire; but I beg you to observe that even among the people where it was most frank and pure, it unquestionably led to evil far greater than any good which demonstrably can be traced to it. Scarcely any of the moral power of Greece depended on her admiration of beauty, or strength in the body. The power of Greece depended on practice in military exercise, involving severe and continual ascetic discipline cf the senses; on a perfect code of military reroism and patriotic honour; on the desire to live by the laws of an admittedly divine justice; and on the vivid conception of the presence of spiritual beings. The mere admiration of physical beauty in the body, and the arts which sought its expression, not only conduced greatly to the fall of Greece, but were the cause of errors and crimes in her greatest time, which must for ever sadden our happiest thoughts of her, and have rendered her example almost useless to the future. 
VIII. SCIENCES OF ORGANIC FORM. I 83

I68. I have named four causes i $f$ her power ; discipline of senses; romantic ideal of heroic honour ; respect for justice ; and relief in God. There was a fifth-the most precious of allthe belief in the purity and force of life in man; and that true reverence for domestic affection, which, in the strangest way, being thc essential strength of every nation under the sun, had yet been lost sight of as the chief element of Greek virtue, though the Iliad itself is nothing but the story of the punishment of the rape of Helen ; and though every Greek hero called himself chiefly by his paternal name,--Tydides, rather than Diomed;-Pelides, rather than Achilles.

Among the new knowledges which the modern sirens tempt you to pursue, the basest and darkest is the endeavour to trace the origin of life, otherwise than in Love. Pardon me, therefore, if I give you a piece of theology to-day : it is a science much closer to your art than anatomy.

I69. All of you who have ever read your Gospels carefully must have wondered, sometimes, what could be the meaning of those words, "If any speak against the Son of Man it shall be forgiven; but if against the Holy Spirit, it 
shall not be forgiven, neither in this world nor in the next."

The passage may have many meanings which I do not know; but one meaning I know positively, and I tell you so just as frankly as I would that I knew the meaning of a verse in Homer.

Those of you who still go to chapel say every day your creed; and, I suppose, too often, less and less every day believing it. Now, you may cease to believe two articles of it, and,-admitting Christianity to be true,-still be forgiven. But I can tell you-you must not cease to believe the third!

You begin by saying that you believe in an Almighty Father. Well, you may entirely lose the sense of that Fatherhood, and yet be forgiven.

You go on to say that you believe in a Saviour Son. You may entirely lose the sense of that Sonship, and yet be forgiven.

But the third article-disbelieve if you dare!

"I believe in the Holy Ghost, the Lord and Giver of life."

Disbelieve that; and your own being is degraded into the state of dust driven by the wind; 
VIII. SCIENCES OF ORGANIC FORM. I $S_{5}$

and the elements of dissolution have entered your very heart and soul.

All Nature, with one voice-with one glory, -is set to teach you reverence for the life communicated to you from the Father of Spirits. The song of birds, and their plumage ; the scent of flowers, their colour, their very existence, are in direct connection with the mystery of that communicated life: and all the strength, and all the arts of men, are measured by, and founded upon, their reverence for the passion, and their guardianship of the purity, of Love.

I70. Gentlemen, - the word by which I at this moment address you-by which it is the first of all your duties through life, to permit all men to address you with truth-that epithet of 'gentle,' as you well know, indicates the intense respect for race and fatherhood-for family dignity and chastity, - which was visibly the strength of Rome, as it had been, more disguisedly, the strength of Greece. But have you enough noticed that your Saxon word 'kindness' has exactly the same relation to 'kin,' and to the Chaucerian 'kind,' that 'gentle' has to 'gentilis'?

Think out that matter a little, and you will 
find that-much as it looks like it-neither chemistry, nor anatomy, nor republicanism, are going to have it all their own way-in the making of either beasts, or gentlemen. They look sometimes, indeed, as if they had got as far as two of the Mosaic plagues, and manufactured frogs in the ditches, and lice on 'he land; but their highest boasters will not claim, yet, so much even as that poor victory.

I71. My friends, let me very strongly recommend you to give up that hope of finding the principle of life in dead bodies; but to take all pains to keep the life pure and holy in the living bodies you have got; and, farther, not to seek your national amusement in the destruction of animals, nor your national safety in the destruction of men; but to look for all your joy to kindness, and for all your strength to domestic faith, and law of ancestral honour. Perhaps you will not now any more think it strange that in beginning your natural history studies in this place, I mean to teach you heraldry, but not anatomy. For, as you learn to read the shields, and remember the stories, of the great houses of England, and find how all the arts that glorified them were founded on the passions 
VIII. SCIENCES OF ORGANIC FORM. 187 that inspired, you will learn assuredly, that the utmost secret of national power is in living with honour, and the utmost secrets of human art are in gentleness and truth. 


\section{LECTURE IX.}

THE STORY OF THE HALCYON.

March 7th, 1872.

172. I mUST to-day briefly recapitulate the purport of the preceding lectures, as we are about now to enter on a new branch of our subject.

I stated, in the first two, that the wisdom of art and the wisdom of science consisted in their being each devoted unselfishly to the service of men; in the third, that art was only the shadow of our knowledge of facts; and that the reality was always to be acknowledged as more beautiful than the shadow. In the fourth lecture I endeavoured to show that the wise modesty of art and science lay in attaching due value to the power and knowledge of other people, when greater than our own; and in the fifth, that the wise self-sufficiency of art and science lay in a proper enjoyment of our own knowledge and 
power, after it was thus modestly esteemed. The sixth lecture stated that sight was a distinctly spiritual power, and that its kindness or tenderness was proportioned to its clearness. Lastly, in the seventh and eighth lectures, I asserted that this spiritual sight, concerned with external aspects of things, was the source of all necessary knowledge in art ; and that the artist has no concern with invisible structures, organic or inorganic.

I73. No concern with invisible structures. But much with invisible things; with passion, and with historical association. And in these two closing lectures, I hope partly to justify myself for pressing on your attention some matters as little hitherto thought of in drawingschools, as the exact sciences have been highly, and, I believe, unjustly, esteemed;-mythology, namely, and heraldry.

I can but in part justify myself now. Your experience of the interest which may be found in these two despised sciences will be my best justification. But to-day (as we are about to begin our exercises in bird-drawing) I think it may interest you to review some of the fables connected with the natural history of a single 
bird, and to consider what effect the knowledge of such tradition is likely to have on our mode of regarding the animated creation in general.

I74. Let us take an instance of the feeling towards birds which is especially characteristic of the English temper at this day, in its entire freedom from superstition.

You will find in your Rudimentary Series (225), Mr. Gould's plate of the lesser Egret,the most beautifil, I suppose, of all birds that visit, or, at least, once visited, our English shores. Perfectly delicate in form, snow-white in plumage, the feathers like frost-work of dead silver, exquisitely slender, separating in the wind like the streams of a fountain, the creature looks a living cloud rather than a bird.

It may be seen often enough in South France and Italy. The last (or last but one ?) known of in England came thirty years ago, and this was its reception, as related by the present happy possessor of its feathers and bones :-

"The little Egret in my possession is a most beautiful specimen: it was killed by a labourer with a stick, in Ake Carr, near Beverley, about I840, and was brought to me, tied up in a pocket-handkerchief, covered with black wet 
mud and blood, in which state it was sent to Mr. Reed, of Doncaster, and restored by him in a most marvellous manner."

I75. Now, you will feel at once that, while the peasant was beating this bird into a piece of bloody flesh with his stick, he could not, in any true sense, see the bird; that he had no pleasure either in the sight of that, or of anything near it.

You feel that he would become capable of seeing it in exact proportion to his desire not to kill it; but to watch it in its life.

Well, that is a quite general law: in the degree in which you delight in the life of any creature, you can see it; no otherwise.

And you would feel, would you not, that if you could enable the peasant rightly to see the bird, you had in great part educated him ?

I76. You would certainly have gone, at least, the third of the way towards educating him. Then the next thing to be contrived would be that he should be able to see a man rightly, as well as a bird; to understand and love what was good in a man, so that supposing his master was a good man, the sight of his master should be a joy to him. You would say that he was 
therein Detter educated than if he wanted to put a gun through a hedge and shoot his master.

Then the last part of education will bewhatever is meant by that beatitude of the pure in heart-seeing God rightly, of which I shall not speak to-day.

177. And in all these phases of education, the main point, you observe, is that it should be a beatitude: and that a man should learn

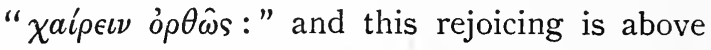
all things to be in actual sight; you have the truth exactly in the saying of Dante when he is brought before Beatrice, in heaven, that his eyes "satisfied themselves for their ten years' thirst."

This, then, I repeat, is the sum of education. All literature, art, and science are vain, and worse, if they do not enable you to be glad; and glad justly.

And I feel it distinctly my duty, though with solemn and true deference to the masters of education in this university, to say that I believe our modern methods of teaching, and especially the institution of severe and frequent examination, to be absolutely opposed to this great end ; and that the result of competitive labour in youth 
is infallibly to make men know all they learn wrongly, and hate the habit of learning; so that instead of coming to Oxford to rejoice in their work, men look forward to the years they are to pass under her teaching as a deadly agony, from which they are fain to escape, and sometimes for their life, must escape, into any method of sanitary frivolity.

I78. I go back to my peasant and his egret. You all think with some horror of this man, beating the bird to death, as a brutal person. He is so; but how far are we English gentlemen, as a body, raised above him ? We are more delicately nurtured, and shrink from the notion of bruising the creature and spoiling its feathers. That is so far right, and well. But in all probability this countryman, rude and cruel though he might be, had some other object in the rest of his day than the killing of birds. And very earnestly I ask you, have English gentlemen, as a class, any other real object in their whole existence than killing birds? If they discern a duty, they will indeed do it to the death; but have the English aristocracy at this moment any clear notion of their duty? I believe solemnly, and without jest, their idea of their caste is that 
its life should be, distinctively from inferior human lives, spent in shooting.

And that is not an idea of caste with which England, at this epoch, can any longer be governed.

I79. I have no time to-day to push my argument farther; but I have said enough, I think, to induce you to bear with me in the statement of my main theorem-that reading and writing are in no sense education, unless they contribute to this end of making us feel kindly towards all creatures; but that drawing, and especially physiologic drawing, is vital education of a most precious kind. Farther, that more good would be done by any English nobleman who would keep his estate lovely in its native wildness; and let every animal live upon it in peace that chose to come there, than will be done, as matters are going now, by the talk of all the Lords in Parliament as long as we live to listen to them; and I will even venture to tell you my hope, though I shall be dead long before its possible fulfilment, that one day the English people will, indeed, so far recognize what education means as to surround this university with the loveliest park in England, twenty miles square; that they will 
forbid, in that environment, every unclean, mechanical, and vulgar trade and manufacture, as any man would forbid them in his own garden; -that they will abolish every base and ugly building, and nest of vice and misery, as they would cast out a devil; - that the streams of the Isis and Cherwell will be kept pure and quiet among their fields and trees; and that, within this park, every English wild flower that can bloom in lowland will be suffered to grow in luxuriance, and every living creature that haunts wood and stream know that it has happy refuge.

And now to our immediate work.

I80. The natural history of anything, or of any creature, divides itself properly into three branches.

We have first to collect and examine the traditions respecting the thing, so that we may know what the effect of its existence has hitherto been on the minds of men, and may have at our command what data exist to help us in our inquiries about it, or to guide us in our own thoughts of it.

We have secondly to examine and describe the thing, or creature, in its actual state, with utmost attainable veracity of observation. 
Lastly, we have to examine under what laws of chemistry and physics the matter of which the thing is made has been collected and constructed.

Thus we have first to know the poetry of it -i.e., what it has been to man, or what man has made of it.

Secondly, the actual facts of its existence.

'Thirdly, the physical causes of these facts, if we can discover them.

I $8 \mathrm{I}$. Now, it is customary, and may be generally advisable, to confine the term 'natural history' to the last two branches of knowledge only. I do not care what we call the first branch; but, in the accounts of animals that I prepare for my schools at Oxford, the main point with me will be the mythology of them; the second, their actual state and aspect, (second, this, because almost always hitherto only half known); and the anatomy and chemistry of their bodies, I shall very rarely, and partially, as I told you, examine at all: but I shall take the greatest pains to get at the creature's habits of life; and know all its ingenuities, humours, delights, and intellectual powers. That is to say, what art it has, and what affection; and how these are prepared for in its external form. 
I82. I say, deliberately and energetically, 'prepared for,' in opposition to the idea, too prevalent in modern philosophy, of the form's being fortuitously developed by repetition of impulse. It is of course true that the aspects and characters of stones, flowers, birds, beasts, and men, are inseparably connected with the conditions under which they are appointed to have existence; but the method of this connection is infinitely varied; so far from fortuitous, it appears grotesquely, often terrifically arbitrary ; and neither stone, flower, beast, nor man can understand any single reason of the arbitrament, or comprehend why its Creator made it thus.

I83. To take the simplest of instances, which happens also to be one of the most important to you as artists, -it is appointed that vertebrated animals shall have no more than four legs, and that, if they require to fly, the two legs in front must become wings, it being against law that they should have more than these four members in ramification from the spine.

Can any law be conceived more arbitrary, or more apparently causeless? What strongly

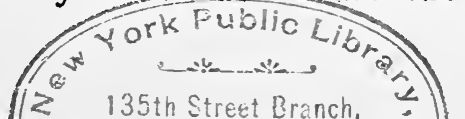


planted three-legged animals there might have been! what symmetrically radiant five-legged ones ! what volatile six-winged ones! what circumspect seven-headed ones! Had Darwinism been true, we should long ago have split our heads in two with foolish thinking, or thrust out, from above our covetous hearts, a hundred desirous arms and clutching hands; and changed ourselves into Briarean Cephalopoda. But the law is around us, and within; unconquerable; granting, up to a certain limit, power over our bodies to circumstance and will; beyond that limit, inviolable, inscrutable, and, so far as we know, eternal.

I 84. For every lower animal, similar laws are established; under the grasp of these it is capable of change, in visibly permitted oscillation between certain points ; beyond which, according to present experience, it cannot pass. The adaptation of the instruments it possesses in its members to the conditions of its life is always direct, and occasionally beautiful; but in the plurality of instances, partial, and involving painful supplementary effort. Some animals have to dig with their noses, some to build with their tails, some to spin with their stomachs: 
their dexterities are usually few-their awkwardnesses numberless ; - a lion is continually puzzled how to hold a bone; and an eagle can scarcely pull the meat off one, without upsetting himself.

I85. Respecting the origin of these variously awkward, imperfectly, or grotesquely developed phases of form and power, you need not at present inquire: in all probability the race of man is appointed to live in wonder, and in acknowledgment of ignorance ; but if ever he is to know any of the secrets of his own or of brutal existence, it will assuredly be through discipline of virtue, not through inquisitiveness of science. I have just used the expression, "had Darwinism been true," implying its fallacy more positively than is justifiable in the present state of our knowledge ; but very positively I can say to you that I have never heard yet one logical argument in its favour, and I have heard, and read, many that were beneath contempt. For instance, by the time you have copied one or two of your exercises on the feather of the halcyon, you will be more interested in the construction and disposition of plume-filaments than heretofore; and you may, perhaps, refer, in hope of help, to $\mathrm{Mr}$. 
Darwin's account of the peacock's feather. I went to it myself, hoping to learn some of the existing laws of life which regulate the local disposition of the colour. But none of these appear to be known ; and I am informed only that peacocks have grown to be peacocks out of brown pheasants, because the young feminine brown pheasants like fine feathers. Whereupon I say to myself, "Then either there was a distinct species of brown pheasants originally born with a taste for fine feathers; and therefore with remarkable eyes in their heads, - which would be a much more wonderful distinction of species than being born with remarkable eyes in their tails,-or else all pheasants would have been peacocks by this time!" And I trouble myself no more about the Darwinian theory.

When you have drawn some of the actual patterns of plume and scale with attention, I believe you will see reason to think that spectra of organic species may be at least as distinct as those of metals or gases ; but learn at all events what they are now, and never mind what they have been.

I86. Nor need you care for methods of classification any more than for the origin of classes. 
Leave the physiologists to invent names, and dispute over them; your business is to know the creature, not the name of it momentarily fashionable in scientific circles. What practical service you can get from the order at present adopted, take, without contention; and as far as possible, use English words, or be sure you understand the Latin ones.

I87. For instance, the order at present adopted in arranging the species of birds, is, as you know, founded only on their ways of using their feet.

Some catch or snatch their prey, and are called "Snatchers"-RAPTORES.

Some perch on branches, and are called "Insitters," or "Upon-sitters "—InSEssores.

Some climb and cling on branches, and are called " Climbers"-scansores.

Some scratch the ground, and are called "Scratchers"-RASORES.

Some stand or wade in shallow water, and, having long legs, are called "Stilt-walkers" GRALLATORES.

Some float, and make oars of their feet, and are called "Swimmers"-NATATORES.

I 88. This classification is unscholarly, because 
there are many snatchers and scratchers who perch as well as the sitters; and many of the swimmers sit, when ashore, more neatly than the sitters themselves; and are most grave insessors, in long rows, on rock or sand: also, ' insessor' does not mean properly a sitter, but a besieger; and it is awkward to call a bird a 'Rasor.' Still, the use of the feet is (on the whole) characteristic, and convenient for first rough arrangement; only, in general reference, it will be better to use plain English words than those stiff Latin ones, or their ugly translations. Linnæus, for all his classes except the stiltwalkers, used the name of the particular birds which were the best types of their class; he called the snatchers "hawks" (Accipitres), the swimmers, geese, (Anseres), the scratchers, fowls, (Gallinae), and the perchers, sparrows, (Passeres). He has no class of climbers; but he has one since omitted by Cuvier, "pies," which, for certain mythological reasons presently to be noted, I will ask you to keep. This will give you seven orders, altogether, to be remembered; and for each of these we will take the name of its most representative bird. The hawk has best right undoubtedly to stand for 
the snatchers; we will have his adversary, the heron, for the stilt-walkers; you will find this very advisable, no less than convenient; because some of the beaks of the stilt-walkers turn down, and some turn up ; but the heron's is straight, and so he stands well as a pure middle type. Then, certainly, gulls will better represent the swimmers than geese; and pheasants are a prettier kind of scratchers than fowls. We will take parrots for the climbers, magpies for the pies, and sparrows for the perchers. Then take them in this order: Hawks, parrots, pies, sparrows, pheasants, gulls, herons ; and you can then easily remember them. For you have hawks at one end, the herons at the other, and sparrows in the middle, with pies on one side and pheasants opposite, for which arrangement you will find there is good reason; then the parrots necessarily go beside the hawks, and the gulls beside the herons.

I 89. The bird whose mythic history I am about to read to you belongs essentially and characteristically to that order of pies, picæ, or painted birds, which the Greeks continually opposed in their thoughts and traditions to the singing birds, representing the one by the 
magpie, and the other by the nightingale. The myth of Autolycus and Philammon, and Pindar's exquisite story of the infidelity of Coronis, are the centres of almost countless traditions, all

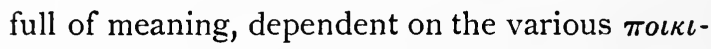
$\lambda i a$, to eye and ear, of these opposed races of birds. The Greek idea of the Halcyon united both these sources of delight. I will read you what notices of it I find most interesting, not in order of date, but of brevity; the simplest first.

190. "And the King of Trachis, the child of the Morning Star, married Alcyone. And they perished, both of them, through their pride; for the king called his wife, Hera; and she her husband, Zeus: but Zeus made birds of them

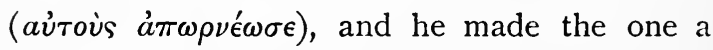
Halcyon, and the other a Sea-mew."-Appollodorus, i. 7,4 .

"When the King of Trachis, the son of Hesperus, or of Lucifer, and Philonis, perished in shipwreck, his wife Alcyone, the daughter of Æolus and Ægiale, for love of him, threw herself into the sea;-who both, by the mercy of the gods, were turned into the birds called IIalcyons. These birds, in the winter-time, build their nests, and lay their eggs, and hatch 
their young on the sea ; and the sea is quiet in those days, which the sailors call the Halcyonia." -Hyginus, Fab. LXV.

I9I. "Now the King of Trachis, the son of Lucifer, had to wife Halcyone. And he, wishing to consult the oracle of Apollo concerning the state of his kingdom, was forbidden to go, by Halcyone, nevertheless he went; and perished by shipwreck. And when his body was brought to his wife Halcyone, she threw herself into the sea. Afterwards, by the mercy of Thetis and Lucifer, they were both turned into the sea-birds called Halcyons. And you ought to know that Halcyone is the woman's name, and is always a feminine noun; but the bird's name is Halcyon, masculine and feminine, and so also its plural, Halcyones. Also those birds make their nests in the sea, in the middle of winter ; in which days the calm is so deep that hardly anything in the sea can be moved. Thence, also, the days themselves are called Halcyonia."-Servius, in Virg. Georg. i. 399.

192. "And the pairing of birds, as I said, is for the most part in spring time, and early summer; except the halcyon's. For the halcyon has its young about the turn of days in winter, 
wherefore, when those days are fine, they are called 'Halcyonine' (ả $\lambda \kappa v o ́ \nu \epsilon \iota \iota)$; seven, indeed, before the turn, and seven after it, as

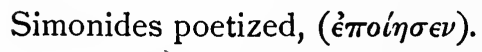

'As, when in the wintry month

Zeus gives the wisdom of calm to fourteen days,

Then the people of the land call it

The hour of wind-hiding, the sacred

Nurse of the spotted Halcyon.'

"And in the first seven days the halcyon is said to lay her eggs, and in the latter seven to bring forth and nourish her young. Here, indeed, in the seas of Greece, it does not always chance that the Halcyonid days are at the solstice; but in the Sicilian sea, almost always. But the æthuia and the laros bring forth their young, (two, or three) among the rocks by the sea-shore; but the laros in summer, the æthuia in first spring, just after the turn of days; and they sit on them as other birds do. And none of these birds lie torpid in holes during the winter; but the halcyon is, of all, seen the seldomest, for it is seen scarcely at all, except just at the setting and turn of Pleias, and then it will but show itself once, and away; flying, perhaps, once round a ship at anchor, and then it is gone instantly."-Aristotle, Hist. Av., v. 8, 9. 
193. "Now we are ready enough to extol the bee for a wise creature, and to consent to the laws by which it cares for the yellow honey, because we adore the pleasantness and tickling to our palates that is in the sweetness of that; but we take no notice of the wisdom and art of other creatures in bringing up their young, as for instance, the halcyon, who as soon as she has conceived, makes her nest by gathering the thorns of the sea-needle-fish; and, weaving these in and out, and joining them together at the ends, she finishes her nest; round in the plan of it, and long, in the proportion of a fisherman's net ; and then she puts it where it will be beaten by the waves, until the rough surface is all fastened together and made close. And it becomes so hard that a blow with iron or stone will not easily divide it; but, what is more wonderful still, is that the opening of the nest is made so exactly to the size and measure of the halcyon that nothing larger can get into it, and nothing smaller ! - so they say ; - no, not even the sea itself, even the least drop of it."-Plutarch: De Amore Prolis.

I have kept to the last Lucian's dialogue, " the Halcyon," to show you how the tone of Christian 
thought, and tradition of Christ's walking on the sea, began to steal into heathen literature.

\section{Socrates-ChaEREPhon.}

194. "Chaerephon. What cry is that, Socrates, which came to us from the beach? how sweet it was; what can it be? the things that live in the sea are all mute.

"Socrates. Yet it is a sea-creature, Chaerephon; the bird called Halcyon, concerning which the old fable runs that she was the daughter of Eolus, and, mourning in her youth for her lost husband, was winged by divine power, and now flies over the sea, seeking him whom she could not find, sought throughout the earth.

"Chacrephon. And is that indeed the Halcyon's cry? I never heard it yet; and in truth it is very pitiful. How large is the bird, Socrates?

"Socrates. Not great; but it has received great honour from the Gods, because of its lovingness; for while it is making its nest, all the world has the happy days which it calls halcyonidæ, excelling all others in their calmness, though in the midst of storm; of which you see this very day is one, if ever there was. Look, 
how clear the sky is, and the sea waveless and calm, like a mirror!

"Chaerephon. You say truly, and yesterday was just such another. But in the name of the Gods, Socrates, how is one to believe those old sayings, that birds were ever changed into women; or women into birds, for nothing could seem more impossible?

I95. "Socrates. Ah, dear Chaerephon, it is likely that we are poor and blunt judges of what is possible and not: for we judge by comparing to human power a power unknown to us, unimaginable, and unseen. Many things, therefore, that are easy, seem to us difficult; and many things unattainable that may be attained; being thus thought of, some through the inexperience, and some through the infantine folly, of our minds. For in very deed every man may be thought of as a child-even the oldest of us, - since the full time of life is little, and as a baby's compared to universal time. And what should we have to say, my good friend, who know nothing of the power of gods or of the spirits of Nature, whether any of such things are possible or not? You saw, Chaerephon, what a storm there was, the day before yesterday; 
it makes one tremble even to think of it again; - that lightning, and thunder, and sudden tempest, so great that one would have thought all the earth falling to ruin; and yet, in a little while, came the wonderful establishing of calm, which has remained even till now. Whether, then, do you think it the greater work, to bring such a calm out of that tormenting whirlwind, and reduce the universe to peace, or to change the form of a woman into that of a bird? For indeed we see how very little children, who know how to knead clay, do something like this also ; often out of one lump they will make form after form, of different natures: and surely to the spirit-powers of Nature, being in vast and inconjecturable excess beyond ours, all such things must be in their hands easy. Or how much do you think heaven greater than thyself -can you say, perchance?

"Chaerephon. Who of men, O Socrates, could imagine or name any of these things?

196. "Socrates. Nay; do we not see also, in comparing man with man, strange differences in their powers and imbecilities? for complete manhood, compared with utter infancy, as of a child five or ten days old, has difference in 
power, which we may well call miraculous : and when we see man excel man so far, what shall we say that the strength of the whole heaven must appear, against ours, to those who can see them together, so as to compare them ? Also, to you and me, and to many like us, sundry things are impossible that are easy to other people; as singing to those ignorant of music, and reading or writing to those ignorant of letters;-more impossible than to make women birds, or birds of women. For Nature, as with chance throw, and rough parable, making the form of a footless and wingless beast in changeable matter; then putting on feet and wings, and making it glitter all over with fair variegation and manifold colour, at last brings out, for instance, the wise bee, maker of the divine honey ; and out of the voiceless and spiritless egg she brings many kinds of flying and foot-going and swimming creatures, using besides (as runs the old Logos) the sacred art of the great Aether. ${ }^{*}$ We then, being altogether mortal and mean, and neither able to see clearly great things nor small, and, for the most part being unable to help ourselves even in our

* Note this sentence respecting the power of the creative Athena. 
own calamities, - what can we have to say about the powers of the immortals, either over halcyons or nightingales? But the fame of fable such as our fathers gave it to us, this, to my children, $\mathrm{O}$ thou bird singing of sorrow, I will deliver concerning thy hymns: and I myself will sing often of this religious and human love of thine, and of the honour thou hast for it from the Gods. Wilt not thou do likewise, O Chaerephon?

"Chaerephon. It is rightly due indeed, $\mathrm{O}$ Socrates, for there is two-fold comfort in this, both for men and women, in their relations with each other.

"Socrates. Shall we not then salute the halcyon, and so go back to the city by the sands, for it is time?

"Chaerephon. Indeed let us do so."

197. The note of the scholiast on this dialogue is the only passage in which I can find any approximately clear description of the Greek halcyon. It is about as large, he says, as a small sparrow; (the question how large a Greek sparrow was we must for the present allow to remain open ;) and it is mixed of green and blue, with gleaming of purple above, and it has a 
slender and long beak : the beak is said to be " chloros," which I venture to translate "green," when it is used of the feathers, but it may mean anything, used of the beak. Then follows the same account as other people's, of the nest-building, except that the nest is compared in shape to a medicinal gourd. And then the writer goes on to say that there are two species of halcyons -one larger than the other, and silent, but the smaller, fond of singing ( $\left.\omega \delta \iota \kappa \eta^{\prime}\right)$; and that the females of these are so true to their mates that, when the latter grow old, the female bird flies underneath them, and carries them wherever they would like to go; and after they die will not eat nor drink anything, and so dies too. "And there is a certain kind of them, of which, if any one hear the voice, it is an altogether true sign to him that he will die in a short time."

I98. You will, I think, forgive me, if after reading to you these lovely fables, I do not distract you, or detain, with the difficult investigation of the degree in which they are founded on the not yet sufficiently known facts of the Kingfisher's life.

I would much rather that you should remain impressed with the effect which the lovely colour 
and fitful appearance of the bird have had on the imagination of men. I may satisfy you by the assurance that the halcyon of England is also the commonest halcyon of Greece and of Palestine; and I may at once prove to you the real gain of being acquainted with the traditions of it, by reading to you two stanzas, certainly among the most familiar to your ears in the whole range of English poetry ; yet which, I am well assured, will sound, after what we have been reflecting upon to-day, almost as if they were new to you. Note especially how Milton's knowledge that Halcyone was the daughter of the Winds, and Ceyx the son of the Morning Star, affects the course of his thought in the successive stanzas-

"But peaceful was the night, Wherein the Prince of light

His reign of peace upon earth began :

The winds with wonder whist,

Smoothly the waters kist,

Whispering new joys to the mild ocean,

Who now hath quite forgot to rave,

While birds of calm sit brooding on the charmèd wave.

' The stars, with deep amaze,

Stand fix'd in steadfast gaze,

Bending one way their precious influence;

And will not take their flight, 
For all the morning light

Of Lucifer, that often warn'd them thence;

But in their glimmering orbs did glow,

Until their Lord Himself bespake, and bid them go."

I99. I should also only weary you if I attempted to give you any interpretation of the much-entangled web of Greek fables connected with the story of Halcyone. You observe that in all these passages I have said "King of Trachis" instead of Ceyx. That is partly because I don't know how to pronounce Ceyx either in Greek or English ; but it is chiefly to make you observe that this story of the sea-mew and Halcyon, now known through all the world, like the seamew's cry, has its origin in the "Rough country," or crag-country, under Mount Eta, made sacred to the Greek mind by the death of Heracles; and observe what strange connection that death has with the Halcyon's story. Heracles goes to this "Rough country" to seek for rest; all the waves and billows of his life having-as he thinks now-gone over him. But he finds death.

As far as I can form any idea of this "rough, or torn, country" from the descriptions of Colonel Leake or any other traveller, it must resemble closely the limestone cliffs just above 
Altorf, which break down to the valley from the ridge of the Windgelle, and give source, at their foot, to faultlessly clear streams,--green-blue among the grass.

You will find Pausanias noting the springs of Thermopylæ as of the bluest water he ever saw ; and if you fancy the Lake Lucerne to be the sea bay running inland from Artemisium, you will have a clear and useful, nor in any serious way, inaccurate, image of the scene where the Greeks thought their best hero should die. You may remember also, with advantage, that Morgarten - the Thermopylæ of Switzerland-lies by the little lake of Egeri, not ten miles from this bay of Altorf ; and that the Heracles of Switzerland is born under those Trachinian crags.

If, farther, you remember that the Halcyon would actually be seen flitting above the blue water of the springs, like one of their waves caught up and lighted by the sun; and the seamews haunting the cliffs, you will see how physical circumstances modify the under-tone of the words of every mythic tradition.

I cannot express to you how strange-how more and more strange every day-it seems to me, that I cannot find a single drawing, nor 
definite account, of scenes so memorable as this, to point you to ; but must guess and piece their image together for you as best I can from their Swiss similitudes. No English gentleman can pass through public school-life without knowing his Trachiniæ; yet I believe, literally, we could give better account of the forms of the mountains in the moon, than we could of CEta. And what has art done to help us? How many Skiddaws or Benvenues, for one Eta,-if one! And when the English gentleman becomes an artpatron, he employs his painter-servant only to paint himself and his house ; and when Turner was striving, in his youth, to enforce the mythology, and picture these very scenes in Greece, and putting his whole strength into the endeavour to conceive them, the noble pictures remained in his gallery; and for bread, he had to paint — Hall, the seat of —-, Esquire, with the carriage drive, the summer-house, and the squire going out hunting.

If, indeed, the squire would make his seat worth painting, and would stay there, and would make the seats, or, shall we call them, forms, of his peasantry, worth painting too, he would be interpreting the fable of the Halcyon to purpose. 
But you must, at once, and without any interpreter, feel for yourselves how much is implied in those wonderful words of Simonides-written six hundred years before Christ;-“" when in the wild winter months, Zeus gives the wisdom of calm;" and how much teaching there is for us in the imagination of past days,- this dreampicture of what is true in days that are, and are to come,-that perfect domestic love not only makes its nest upon the waves, but that the waves will be calm that it may.

200. True, I repeat, for all ages, and all. people, that, indeed, are desirous of peace, and loving in trouble! But what fable shall we invent, what creature on earth or sea shall we find, to symbolize this state of ours in modern England? To what sorrowful birds shall we be likened, who make the principal object of our lives dispeace, and unrest; and turn our wives and daughters out of their nests, to work for themselves?

Nay, strictly speaking, we have not even got so much as nests to turn them out of. I was infinitely struck, only the other day, by the saying of a large landed proprietor (a good man, who was doing all he could for his tenantry, 
and building new cottages for them), that the best he could do for them, under present conditions of wages, and the like, was, to give them good drainage and bare walls.

"I am obliged," he said to me, "to give up all thought of anything artistic, and even then, I must lose a considerable sum on every cottage I build."

201. Now, there is no end to the confused states of wrong and misery which that landlord's experience signifies. In the first place, no landlord has any business with building cottages for his people. Every peasant should be able to build his own cottage,-- to build it to his mind; and to have a mind to build it too. In the second place, note the unhappy notion which has grown up in the modern English mind, that wholesome and necessary delight in what is pleasant to the eye, is artistic affectation. You have the exponent of it all in the central and mighty affectation of the Houses of Parliament. A number of English gentlemen get together to talk; they have no delight whatever in any kind of beauty; but they have a vague notion that the appointed place for their conversation should be dignified and ornamental ; and they build over 
their combined heads the absurdest and emptiest piece of filigree,-and, as it were, eternal foolscap in freestone,-which ever human beings disgraced their posterity by. Well, all that is done, partly, and greatly, in mere jobbery ; but essentially also in a servile imitation of the Hottel-de-Ville builders of old time; but the English gentleman has not the remotest idea that when Hôtels-de-Ville were built, the ville enjoyed its hotel; - the town had a real pride in its town hall, and place of council, and the sculptures of it had precious meaning for all the populace.

202. And in like manner, if cottages are ever to be wisely built again, the peasant must enjoy his cottage, and be himself its artist, as a bird is. Shall cock-robins and yellow-hammers have wit enough to make themselves comfortable, and bullfinches peck a Gothic tracery out of dead clematis, - and your English yeoman be fitted by his landlord with four dead walls and a drainpipe? That is the result of your spending $300,000 l$ a year at Kensington in science and art, then? You have made beautiful machines, too, wherewith you save the peasant the trouble of ploughing and reaping, and threshing; and 
after being saved all that time and toil, and getting, one would think, leisure enough for his education, you have to lodge him also, as you drop a puppet into a deal box, and you lose money in doing it! and two hundred years ago, without steam, without electricity, almost without books, and altogether without help from "Cassell's Educator" or the morning newspapers, the Swiss shepherd could build himself a châlet, daintily carved, and with flourished inscriptions, and with red and blue and white

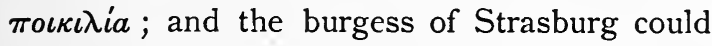
build himself a house like this I showed you, and a spire such as all men know ; and keep a precious book or two in his public library, and praise God for all : while we,-what are we good for, but to damage the spire, knock down half the houses, and burn the library,-and declare there is no God but Chemistry?

203. What are we good for? Are even our machines of destruction useful to us? Do they give us real power? Once, indeed, not like halcyons, but like sea-eagles, we had our homes upon the sea ; fearless alike of storm or enemy, winged like the wave petrel; and as Arabs of an indeed pathless desert, we dwelt in the 
presence of all our brethren. Our pride is fallen; no reed shaken with the wind, near the little singing halcyon's nest, is more tremulous than we are now; though we have built iron nests on the sea, with walls impregnable. We have lost our pride-but have we gained peace ? Do we even care to seek it, how much less strive to make it?

204. Have you ever thought seriously of the meaning of that blessing given to the peacemakers? People are always expecting to get peace in heaven; but you know whatever peace they get there will be ready made. Whatever making of peace they can be blest for, must be on the earth here : not the taking of arms against, but the building of nests amidst, its "sea of troubles." Difficult enough, you think? Perhaps so, but I do not. see that any of us try. We complain of the want of many things-we want votes, we want liberty, we want amusement, we want money. Which of us feels, or knows, that he wants peace?

205. There are two ways of getting it, if you do want it. The first is wholly in your own power; to make yourselves nests of pleasant thoughts. Those are nests on the sea indeed. 
but safe beyond all others; only they need much art in the building. None of us yet know, for none of us have yet been taught in early youth, what fairy palaces we may build of beautiful thought-proof against all adversity. Bright fancies, satisfied memories, noble histories, faithful sayings, treasure-houses of precious and restful thoughts, which care cannot disturb, nor pain make gloomy, nor poverty take away from us-houses built without hands, for our souls to live in.

206. And in actual life, let me assure you, in conclusion, the first 'wisdom of calm,' is to plan, and resolve to labour for, the comfort and beauty of a home such as, if we could obtain it, we would quit no more. Not a compartment of a model lodging-house, not the number so-and-so of Paradise Row ; but a cottage all of our own, with its little garden, its pleasant view, its surrounding fields, its neighbouring stream, its healthy air, and clean kitchen, parlours, and bedrooms. Less than this, no man should be content with for his nest ; more than this few should seek : but if it seem to you impossible, or wildly imaginary, that such houses should ever be obtained for the greater part of the English peop!e, 
again believe me, the obstacles which are in the way of our obtaining them are the things which it must be the main object now of all true science, true art, and true literature to overcome Science does its duty, not in telling us the causes of spots in the sun; but in explaining to us the laws of our own life, and the consequences of their violation. Art does its duty, not in filling monster galleries with frivolous, or dreadful, or indecent pictures; but in completing the comforts and refining the pleasures of daily occurrence, and familiar service : and literature does its duty, not in wasting our hours in political discussion, or in idle fiction; but in raising our fancy to the height of what may be noble, honest, and felicitous in actual life;-in giving us, though we may ourselves be poor and unknown, the companionship of the wisest fellow-spirits of every age and country, - and in aiding the communication of clear thoughts and faithful purposes, among distant nations, which will at last breathe calm upon the sea of lawless passion, and change into such halcyon days the winter of the world, that the birds of the air may have their nests in peace, and the Son of Man, where to lay His head. 


\section{LECTURE $\mathrm{X}$.}

THE HERALDIC ORDINARIES.

\section{March 9th, I872.}

207. In my last lecture, I endeavoured to illustrate to you the use of art to the science of physiology. I am to-day to introduce to you its elementary forms as an exponent of the science of history. Which, speaking with perfect accuracy, we ought to call, also, "physiology," or natural history of man; for it ought to be in truth the history of his Nature; and not merely of the accidents which have befallen him. Do we not too much confuse the important part of the science with the unimportant?

In giving the natural history of the lion, you do not care materially where such and such a lion was trapped, or how many sheep it had eaten. You want to know what sort of a minded and shaped creature it is, or ought to be. But in all our books of human history we only care to tell what has happened to men, and how 
many of each other they have, in a manner, eaten, when they are, what Homer calls $\delta \eta \mu o-$ Bópoı, people-eaters; and we scarcely understand, even to this day, how they are truly minded. Nay, I am not sure that even this art of heraldry, which has for its main object the telling and proclamation of our chief minds and characters to each other, and keeping record of descent by race, as far as it is possible, (or, under the present aspect of Darwinism, pleasant,) to trace it;-I am not sure that even heraldry has always understood clearly what it had to tell. But I am very sure it has not been understood in the telling.

208. Some of you have, I hope, looked at this book* of Arthur Helps, on 'War and Culture,' about which I cannot now say what I wou'd, because he has done me the grace of dedicating it to me; but you will find in it, directly bearing on our present subject, this story about heraldry:

"A friend of mine, a physician, became entangled in the crowd at Kennington on that memorable evening when a great Chartist row was expected, and when Louis Napoleon armed

* Conversations on War and General Culture. 
himself with a constable's staff to support the cause of order. My friend observed a young man of pleasant appearance, who was very busy in the crowd, and appeared to be a leader amongst them. Gradually, by the pressure of the crowd, the two were brought near together, and the good doctor had some talk with this fiery partisan. They exchanged confidences; and to his astonishment, the doctor found that this furious young Chartist gained his livelihood, and a very good livelihood too, by heraldic painting--by painting the coats-of-arms upon carriages. Now, if you can imagine this young man's darling enterprise to have been successful, if Chartism had prevailed, what would have become of the painting of arms upon carriage-panels? I believe that my good doctor insinuated this suggestion to the young man, and that it was received with disdain. I must own, therefore, that the utile, even when brought home to a man's self, has much less to do with people's political opinions and desires, than might at first be supposed. Indeed, I would venture to maintain, that no great change has ever been produced in the world by motives of self-interest. Sentiment, that thing which many wise people affect to despise, is the 
commanding thing as regards popular impulses and popular action."

209. This last sentence would have been wholly true, had Mr. Helps written 'no great living change.' The changes of Dissolution are continually produced by self-interest,-for instance, a great number of the changes in your methods of life in England just now, and many of those in your moral temper, are produced by the percentage on the sale of iron. And I should have otherwise interpreted the heroism of the young Chartist, and said that he was moved on the Ioth of April, by a deep under-current of self-interest; that by overthrowing Lordship, he expected to get much more for himself than his salary as an heraldic painter; and that he had not, in painting his carriage-panels, sentiment enough, or even sentiment at all.

"Paint me my arms,-_" said Giotto, as the youth threw him his white shield with that order - " he speaks as if he were one of the Bardi !" Our English panel-painter had lost the consciousness that there yet remained above him, so much as one, of the Bardi.

May not that be somewhat the Bardi's fault? in that they have not taught their Giottos, lately, 
the function of heraldry, or of any other higher historical painting.

We have, especially, to-day, to consider what that function is.

2IO. I said that the function of historical painting, in representing animals, is to discern and record what is best and most beautiful in their ways of life, and their forms; so also, in representing man, it is to record of man what has been best in his acts and way of life, and fairest in his form.

But this way of the life of man has been a long one. It is difficult to know it-more difficult to judge; to do either with complete equity is impossible; but it is always possible to do it with the charity which does not rejoice in iniquity.

2I I. Among the many mistakes we have lately fallen into, touching that same charity, one of the worst is our careless habit of always thinking of her as pitiful, and to be concerned only with miserable and wretched persons; whereas her chief joy is in being reverent, and concerned mainly with noble and venerable persons. Her poorest function is the giving of pity; her highest is the giving of praise. For there are many men, who, however fallen, do not like 
to be pitied ; but all men, however far risen, like to be praised.

212. I had occasion in my last lecture to express my regret that the method of education in this country has become so distinctly competitive. It . is necessary, however, to distinguish carefully between the competition which is for the means of existence, and that which is for the praise of learning. For my own part, so far as they affect our studies here, I equally regret both : but competition for money I regret absolutely ; competition for praise, only when it sets the reward for too short and narrow a race. I want you to compete, not for the praise of what you know, but for the praise of what you become; and to compete only in that great school, where death is the examiner, and God the judge. For you will find, if you look into your own hearts, that the two great delights, in loving and praising, and the two great thirsts, to be loved and praised, are the roots of all that is strong in the deeds of men, and happy in their repose. We yet, thank Heaven, are not ashamed to acknowledge the power of love; but we confusedly and doubtfully allege that of honour; and though we cannot but instinctively triumph still, over a 
won boat-race, I suppose the best of us would shrink somewhat from declaring that the love of praise was to be one of the chief motives of their future lives.

2I3. But I believe you will find it, if you think, not only one of the chief, but absolutely the chief, motive of human action; nay, that love itself is, in its highest state, the rendering of an exquisite praise to body and soul; and our English tongue is very sacred in this; for its Saxon word, love, is connected, through the old French verb, loer, (whence louange), with the Latin, ' laus,' not ' amor.'

And you may sum the duty of your life in the giving of praise worthily, and being yourselves worthy of it.

214. Therefore in the reading of all history, your first purpose must be to seek what is to $1 \mathrm{e}$ praised; and disdain the rest: and in doing so, remember always that the most important part of the history of man is that of his imagination. What he actually does, is always in great part accidental; it is at best a partial fulfilment of his purpose ; and what we call history is often, as I said, merely a record of the external accidents which befall men getting together in large 
crowds. The real history of mankind is that of the slow advance of resolved deed following laboriously just thought: and all the greatest men live in their purpose and effort more than it is possible for them to live in reality. If you would praise them more worthily, it is for what they conceived and felt; not merely for what they have done.

215. It is therefore a true historian's work diligently to separate the deed from the imagination; and when these become inconsistent, to remember that the imagination, if precious at all, is indeed the most precious. It is no matter how much, or how little of the two first books of Livy may be literally true. The history of the Romans is the history of the nation which could conceive the battle of the Lake Regililus. I have rowed in rough weather on the Lake of the four cantons often enough to know that the legend of Tell is, in literal detail, absurd : but the history of Switzerland is that of the people who expressed their imagination of resistance to injustice by that legend, so as to animate their character vitally to this day.

216. But in no part of history does the ideal 
separate itself so far from the reality; and in no part of it is the ideal so necessary and noble, as in your own inherited history-that of Christian Chivalry.

For all English gentlemen this is the part of the tale of the race of man which it is most essential for them to know. They may be proud that it is also the greatest part. All that hitherto has been achieved of best,-all that has been in noble preparation instituted,-is begun in the period, and rooted in the conception, of Chivalry.

You must always carefully distinguish that conception from the base strength of the resultless passions which distort and confuse it. Infinitely weaker, the ideal is eternal and creative ; the clamorous rages pass away,-ruinous it may be, prosperous it may be, for their time ;-but insignificant for ever. You find kings and priests alike, always inventing expedients to get money ; you find kings and priests alike, always inventing pretexts to gain power. If you want to write a practical history of the Middle Ages, and to trace the real reasons of the things that actually happened, investigate first the history of the money; and then of the quarrels for office and 
territory. But the things that actually happened were of small consequence-the thoughts that were developed are of infinite consequence.

2I7. As I was walking back from Hincksey last evening, somewhat discomfited by the look of bad weather, and more in myself, as I thought over this closing lecture, wondering how far you thought I had been talking idly to you, instead of teaching you to draw, through this term, I stopped before Messrs. Wyatt's window ; caught -as it was intended every one should be-by this display of wonderful things. And I was very unhappy as I looked, for it seemed to me you could not but think the little I could show you how to do quite valueless; while here were produced, by mysteries of craft which you might expect me at once to explain, brilliant water-colours in purple and gold, and photographs of seawaves, and chromolithotints of beautiful young ladies, and exquisitely finished engravings of all sorts of interesting scenes, and sublime personages: patriots, saints, martyrs, penitents, and who not! and what not! all depicted with a dexterity which it has cost the workmen their life's best energy to learn, and requires great cleverness thus to apply. While in your room 
for study, there are only ugly photographs of Dürers and Holbeins, and my rude outlines from leaves, and you scarcely ever hear me say anything in praise of that delightful and elaborate modern art at all.

218. So I bought this Madonna, * which was the prettiest thing I saw : and it will enable me to tell you why this modern art is, indeed, so little to be studied, even at its best. I think you will all like the plate, and you ought to like it ; but observe in what its beauty consists. First, in very exquisite line engraving : against that I have nothing to say, feeling the greatest respect for the industry and skill it requires. Next, in a grace and severity of action which we all are ready to praise ; but this is not the painter's own bestowing; the trick of it is learned from Memling and Van Eyck, and other men of the northern religious school. The covering of the robe with jewels is pleasing to you; but that is learned from Angelico and John Bellini; and if you will compare the jewel-painting in the John Bellini (Standard No. 5), you will find this false and formal in comparison. Then the face is much dignified by having a crown set on it- 
which is copied from the ordinary thirteenth century form, and ill done. The face itself is studied from a young German mother's, and is only by the painter's want of skill made conventional in expression, and formal in feature. It would have been wiser and more difficult to have painted her as Raphael or Reynolds would, with true personal resemblance, perfected in expression.

2 I9. Nevertheless, in its derivative way, this is very lovely. But I wish you to observe that it is derivative in all things. The dress is derivative; the action, derivative: above all, the conception is derivative altogether, from that great age of Christian chivalry, which, in art and thought alike, surpassed the Greek chivalry, because it added to their enthusiasm of patriotism the enthusiasm of imaginative love, sanctified by this ruling vision of the Madonna, as at once perfect maid and perfect mother.

And your study of the art of the middle ages must begin in your understanding how the men of them looked on Love as the source of all honour, as of life; and how, from the least thing to the greatest, the honouring of father and mother, the noble esteem of children, and the 
sincere respect for race, and for the courtesies and prides that graced and crowned its purity, were the sources of all their virtue, and all their joy.

220. From the least things, I say, to the greatest. I am to speak to-day of one of, apparently, the least things; which is, indeed, one of the greatest. How much of the dignity of this Madonna, do you suppose, depends on the manner she bears her dress, her crown, her jewels, and her sceptre?

In peasant and prince alike, you will find that, ultimately, character is truly heralded in dress; and that splendour in dress is as necessary to man as colour to birds and flowers, but splendour with more meaning. Splendour observe, however, in the true Latin sense of the word; brightness of colour; not gaudiness: what I have been telling you of colour in pictures will apply equally to colour in dress : vulgarity consists in the insolence and discord of it, not in brightness.

22 I. For peasant and prince alike, in healthy national order, brightness of dress and beautiful arrangement of it are needful. No indication of moral decline is more sure than the squalor 
of dress among the lower orders, and the fear or shame of the higher classes to bear their proper insignia.

Such fear and shame are singularly expressed, here in Oxford, at this hour. The nobleman ceases to wear the golden tassel in his cap, so accepting, and publicly heralding his acceptance of, the popular opinion of him that he has ceased to be a nobleman, or noteworthy person.* And the members of the University, generally, shrink from wearing their academical dress, so accepting, and publicly heralding their acceptance of, the popular opinion that everybody else may be as good scholars as they. On the other hand, I see continually in the streets young men in bright costumes of blue and white ; in such evidently proud heraldry proclaiming their conviction that the chief object of residence in Oxford is learning to row ; the rowing itself being, I

* "Another stride that has been taken appears in the perishing of heraldry. Whilst the privileges of nobility are passing to the middle class, the badge is discredited, and the titles of lordship are getting musty and cumbersome. I wonder that sensible men have not been already impatient of them. They belong, with wigs, powder, and scarlet coats, to an earlier age, and may be advantageously consigned, with paint and tattoo, to the dignitaries of Australia and Polynesia."-R. W. Emerson (English Traits). 
imagine, not for real boat service, but for purposes of display.

222. All dress is thus heraldic; a soldier's dress only more definitely so, in proclaiming the thing he means to die as well as to live for ; but all is heraldic, from the beggar's rag to the king's diadem; it may be involuntarily, it may be, insolently; but when the characters of men are determined, and wise, their dress becomes heraldic reverently, and in order. "Togam e tugurio proferre uxorem Raciliam jubet;" and Edie Ochiltree's blue gown is as honourably heraldic as a knight's ermine.

223. The beginning of heraldry, and of all beautiful dress, is, however, simply in the wearing of the skins of slain animals. You may discredit, as much as you choose, the literal meaning of that earliest statement, "Unto Adam also, and to his wife, did the Lord God make coats of skin, and clothed them :" but the figurative meaning of it only becomes the stronger. For if you think of the skins of animals as giving the four great materials of dress-leather, fur, wool, and down, you will see in this verse the summary of what has ever since taken place in the method of the providence of the Maker of 
Man and beast, for the clothing of the naked creature who was to rule over the rest.

224. The first practical and savage use of such dress was that the skin of the head of the beast became a covering for the head of its slayer; the skin of its body his coat; the skin of the fore legs was knotted in front, and the skin of the hind legs and tail became tassels, the jags of the cut edges forming a kind of fringe here and there.

You have thus the first conception of a helmet with the mane of the animal for its crest or plume, and the first conception of a cuirass variously fringed, striped, or spotted; in complete accoutrement for war, you have to add spear, (or arrow), and shield. The spear is properly a beam of wood, iron pointed; the shield a disk of leather, iron fronted.

And armed strength for conflict is symbolized for all future time by the Greeks, under the two types of Heracles and Athena; the one with the low lion's crest and the arrow, the other with the high horse's crest, and the spear; one with the lion-skin, the other with the goat-skin ;both with the round shield.

225. The nebris of Dionusos and leopard-skin 
of the priests of Egypt relate to astronomy, not war ; and the interest in their spots and bars, as variously symbolic, together with real pleasure in their grotesqueness, greatly modified the entire system of Egyptian colour-decoration. On the earliest Greek vases, also, the spots and bars of the animals are carried out in spots or chequers upon the ground, (sometimes representing flowers), and the delight in "divers colours of needlework," and in fantasy of embroidery, gradually refine and illumine the design of Eastern dress. But only the patterns derived from the colours of animals become classical in heraldry under the general name of "furres," one of them "vaire " or verrey (" the variegated fur,") rudely figuring the material composed of the skins of small animals sewn together, alternately head to tail ; the other, ermine, peculiarly honourable, from the costliness, to southern nations, of the fur it represents.

226. The name of the principal heraldic colour has a similar origin : the " rams' skins dyed red" which were used for the curtains of the Jewish tabernacle, were always one of the principal articles of commerce between the east and west: in mediæval Latin they were called "gulae," 
and in the French plural "gules," so that to be dressed in "gules" came gradually to mean being dressed in the particular red of those skins, which was a full soft scarlet, not dazzling, but warm and glowing. It is used, in opposition to darker purple, in large masses in the fresco painting of later Rome;-is the dominant colour of ornamental writing in the middle ages (giving us the ecclesiastical term "rubric"), and asserts itself finally, and most nobly, in the fresco paintings of Ghirlandajo and Luini. I have tried to represent very closely the tint of it Luini has given to St. Catherine's mantle, in my study in your schools. Titian keeps it also as the keynote of his frescoes; so also Tintoret; but Raphael, Correggio, and Michael Angelo, all substituted orange for it in opposition to purple; and the entire scheme of colour in the Vatican frescoes is of orange and purple, broken by green and white, on a ground of grey. This orange and purple opposition in meaner hands became gaudy and feeble, and the system of mediæval colour was at last totally destroyed by it; the orange remaining to this day the favourite, and most distinctive, hue in bad glass painting 
227. The forms of dress, however, derived from the skins of animals are of much more importance than the colours. Of these the principal is the crest, which is properly the mane of lion or horse. The skin of the horse was neither tough, nor of convenient size for wearing; but the classical Greek helmet is only an adaptation of the outline of its head, with the mane floating behind: many Etruscan helmets have ears also, while in mediæval armour, light plates, cut into the shape of wings of birds, are often placed on each side of the crest, which then becomes not the mane of the animal merely, but the image of the entire creature which the warrior desires to be renowned for having slain.

228. The Heraldic meaning of the crest is accordingly, first, that the Knight asserts himself to have prevailed over the animal it represents ; and to be stronger than such a creature would be, therefore, against his human enemies. Hence, gradually, he considers himself invested with the power and character of the slain creature itself ; and, as it were, to have taken from it, for his spoil, not its skin only but its strength. The crest, therefore, is the heraldic indication of 
personality, and is properly to be distinguished from the bearing on the shield, because that indicated race; but the crest, personal character and valour.

229. I have traced the practical truth which is the foundation of this idea of the transmitted strength of the slain creature becoming the inheritance of its victor, in the account given of the coins of Camarina, in "The Queen of the Air." But it is strange and sad to reflect how much misery has resulted, in the history of man, from the imaginative excuse for cruelty afforded by the adopted character of savage animals; and how many wolves, bears, lions, and eagles, have been national symbols, instead of gentler creatures. Even the heraldic symbol of Christ is in Italy oftener the lion than the lamb: and among the innumerable painters of his Desert Prophet, only Filippo Lippi understood the full meaning of the raiment of camel's hair, and made him wear the camel's skin, as Heracles the Lion's.

230. Although the crest is thus essentially an expression of personal character, it practically becomes hereditary; and the sign on shield and helmet is commonly the same. But the shield has a system of bearings peculiar to itself, to 
which I wish especially to direct your attention to-day.

Our word 'shield' and the German 'schild ' mean 'the covering thing,' that behind which you are sheltered, but you must be careful to distinguish it from the word shell, which means properly a scale or plate, developed like a fish's scale, for the protection of the body.

There are properly only two kinds of shields, one round and the other square, passing into oval and oblong; the round one being for use in free action, the square one for adjustment to ground or walls; but, on horseback, the lower part of the shield must be tapered off, in order to fall conveniently on the left side of the horse.

And, therefore, practically you have two great forms of shield; the Greek round one, for fighting on foot, or in the chariot, and the Gothic pointed one, for fighting on horseback. The oblong one for motionless defence is, however, almost always given to the mythic figure of Fortitude, and the bearings of the Greek and Gothic shields are always designed with reference to the supposed figures of the circle and square.

The Greek word for the round shield is 
aspis.' I have no doubt, merely a modification, of 'apsis,' the potter's wheel ; the proper word for the Gothic shield is 'ecu,' from the Latin 'scutum,' meaning a shield covered with leather. From 'ecu' you have 'ecuyer ;'-from scutum 'scutiger,' both passing into our English 'squire.'

231. The aspis of the Greeks might be much heavier than the Gothic shield, because a Greek never rode fully armed; his object was to allow both to his horse and to himself the most perfect command of limb compatible with protection; if, therefore, he was in full armour, and wanted his horse to carry him, he put a board upon wheels, and stood on that, harnessing sometimes to it four horses of the highest breed abreast. Of all hitherto practised exertions of manual dexterity, the driving thus at full speed over rough ground, standing in the chariot, is, as far as I know, the greatest ever attained by general military discipline.

It is true that to do anything perfectly well is about equally difficult; and I suppose that in a chariot race, a tournament, or a modern game at cricket, the manual art of the most highlytrained men would be almost equally fine; still, practically, in Gothic chiyalry, the knight trusted 
more to his weight and less to his skill than a Greek did; nor could a horse's pace under armour ever render precision of aim so difficult as at unarmed speed.

232. Another great difference of a parallel kind exists in the knight's body armour. A Greek never hopes to turn a lance by his cuirass, nor to be invulnerable except by enchantment, in his body-armour, because he will not have it cumbrous enough to impede his movements; but he makes his shield, if possible, strong enough to stop a lance, and carries it as he would a piece of wall : a Gothic knight, on the contrary, endeavoured to make his coat armour invulnerable, and carried the shield merely to ward thrusts on the left side, never large enough to encumber the arm that held the reins. All fine design in Gothic heraldry is lounded, therefore, on the form of a short, hut pointed shield, convex enough to throw the point of a spear aside easily ; a form roughly extending from the beginning of the twelfth to the middle of the fifteenth century, but of which the most beautiful types are towards the end of the thirteenth.

233. The difference in method of device 
between the Gothic and classic shields resulted partly from this essential difference in form. The pointed shield, having definitely two sides, like a pointed arch, and a determined position, naturally suggested an arrangement of bearings definitely on one side or the other, or above, or below the centre, while the Greek shield had its boss, or its main bearing, in the centre always, with subordinate decoration round. Farther, the Gothic fineness of colour-instinct seized at once on this division of parts as an opportunity for inlaying or counterchanging colours; and finally, the respect for race, carried out by registry of the remotest branches of noble families, compelled the Gothic heralds of later times to use these methods of dividing or quartering in continually redoubled complexity.

234. Essentially, therefore, as distinguished from the classic shield, the Gothic one is particoloured beneath its definite bearings, or rather, bi-coloured; for the tinctures are never more than two in the main design of them; and the specific methods of arrangement of these two masses of colour have deeper and more ancient heraldic significance than, with few exceptions, their superimposed bearings. I have arranged 
the twelve principal ones ${ }^{*}$ in the 7 th of your rudimentary exercises, and they will be entirely fixed in your minds by once drawing it.

235. Observe respecting them.

I. The Chiefe; a bar of colour across the upper part of the shield, signifies authority or chief-dom, as the source of all order, power, and peace.

2. The cross, as an ordinary, distinguished from the cross as a bearing, consists simply of two bars dividing the shield into four quarters; and, I believe, that it does not in this form stand properly as a symbol of Christian faith, but only as one of Christian patience and fortitude. The cross as a symbol of faith is terminated within the field.

3. The Fesse, a horizontal bar across the middle of the shield, represents the knight's girdle, or anything that binds and secures, or continues. The word is a corruption of fascia. Sir Francis Drake received for arms from Queen

* Charges which "doe peculiarly belong to this art, and are of ordinary use therein, in regard whereof they are called 'ordinaries.'"-See Guillim, sect. ii. chap. iii. (Ed. I638.)

"They have also the title of honourable ordinaries in that the court armour is much honoured thereby." The French call them "pièces honorables." 
Elizabeth a Fesse waved between two polestars, where it stands for the waved surface of the sea, and partly, also, to signify that Sir Francis put a girdle round the earth; and the family of Drummond carries three diminutive Fesses, or bars, waved, because their ancestor brought Queen Margaret safe through many storms.

4. The Bend, an oblique bar descending from right to left of the holder of the shield, represents the sword belt. The Latin balteus and balteum are, I believe, the origin of the word. They become bendellus and bendellum; then bandeau and bande. Benda is the word used for the riband round the neck of St. Etheldreda, in the account of her death quoted by Du Cange. I believe, also, the fesse stands often for the cross-bar of the castle gate, and the bend for its very useful diagonal bar: this is only a conjecture, but I believe as likely to be true as the idea, certainly admitted in heraldry, that the bend sometimes stands for a scaling ladder: so also the next four most important ordinaries have all an architectural significance.

5. The Pale, an upright bar dividing the shield in half, is simply an upright piece of 
timber in a palisade. It signifies either defence or enclosure.

6. The Pile, a wedge-shaped space of colour with the point downwards, represents what we still call a pile; a piece of timber driven into moist ground to secure the foundation of any building.

7. The Canton, a square space of colour in either of the upper corners of the shield, signifies the corner-stone of a building. The origin and various use of this word are very interesting. The Greek $\kappa a \nu \theta o$ s, used by Aristotle for the corner of the eyes, becomes canto, and then cantonus. The French coin (corner), is usually derived from the Latin cuneus; but I have no doubt it is one corruption of canton: the mediæval-Latin cantonus is either an angle or recess, or a four-square corner-stone. The heraldic canton is the corner-stone of a building, and the French cantonnier is a road-mender, because the essential thing in repairing a road is to get its corner or edge firm.

8. The Chevron, a band bent at an angle (properly a right angle), with its point upwards, represents the gable or roof of a house. Thus the four last-named ordinaries represent the four essentials of a fixed habitation: the pale, 
its enclosure within a given space of ground; the pile, its foundation; the canton, its wall, and the chevron its roof.

9. The Orle, a narrow band following the outline of the shield midway between its edge and centre, is a more definite expression of enclosure or fortification by moat or rampart. The relations of this word, no less than that of the canton, are singular, and worth remembering. Du Cange quotes under it an order of the municipality of Piacenza, that always, in the custom-house where the salt-tax was taken, "a great orled disk" should be kept; "dischus magnus orlatus," i.e., a large plate, with a rim, in which every day fresh salt should be placed. Then note that the word disk is used in the Middle Ages, either for a plate, or a table, (the "holy disk" is the patina of the sacrament), but most generally for a table, whence you get the old German disch; our dish, the French disner, diner ; and our dinner. The disk cut out into a ring becomes a quoit, which is the simplest form of orle. The word 'orle' itself comes, I believe, from ora, in old Latin, which took a diminutive, orula; or perhaps the ' 1 ' was put in merely to distinguish, to the ear, a 
margined thing, 'orlatus,' from a gilded thing, 'auratus.' It stands for the hem of a robe, or the fillet of a crown, as well as for any margin; and it is given as an ordinary to such as have afforded protection and defence, because it defends what is within it. Reduced to a narrow band, it becomes a 'Tressure.' If you have a sovereign of 1860 to 1870 in your pocket, and look at the right hand upper corner of the Queen's arms, you will see the Scottish Lion within the tressure decorated with fleur-de-lys, which Scotland bears in memory of her treaty with Charlemagne.

IO. The Gyron, a triangular space of colour with its point in the centre of the shield, derives its name from the old Latin gyro, a fold, " pars vestis quâ laxior fit, et in superiori parte contracta, in largiorem formam in imo se explicat." The heraldic 'gyron,' however, also has a collateral reference to, and root in, the word 'gremium,' bosom or lap ; and it signifies properly the chief fold or fall of the dress either over the bosom, or between the knees; and has whatever symbolic expression may be attributed to that fold, as a sign of kindness or protection. The influence of the lines taken by softly falling 
drapery in giving gentleness to the action of figures was always felt by the Gothic artists as one of the chief elements of design; and the two constantly repeated figures of Christ holding souls in the 'gremium' of His robe, and of the Madonna casting hers over suppliants, gave an inevitably recognised association to them.

I I. The Flasque, a space of colour terminated by a curved line on each flank of the shield, derives its name from the Latin flecto, and is the bearing of honour given for successful embassy. It must be counted among the ordinaries, but is of rare occurrence in what groups of authentic bearings I have examined.

12. The Saltire, from salir, represents the securest form of machine for mounting walls; it has partly the same significance as the ladder of the Scaligers, but, being properly an ordinary, and not a bearing, has the wider general meaning of successful ascent, not that of mere local attack. As a bearing, it is the St. Andrew's Cross.

236. These twelve forms of ordinary then, or first colour divisions of the shield, represent 
symbolically the establishment, defence, and exaltation of the Knight's house by his Christian courage; and are in this symbolism, different from all other military bearings. They are throughout essentially founded on the "quartering" or division of the field into four spaces by the sign of the Cross : and the history of the chivalry of Europe is absolutely that of the connection of domestic honour with Christian faith, and of the exaltation of these two sentiments into the highest enthusiasm by cultivated imagination.

The means of this culture by the finer arts; the errors, or falls, of the enthusiasm so excited ; its extinction by avarice, pride, and lust, in the period of the (so called) Renaissance, and the possibility of a true Renaissance, or Restoration, of courage and pure hope to Christian men in their homes and industries, must form the general subject of the study into which I have henceforth to lead you. In a future course of lectures it will be my endeavour to show you, in the elementary forms of Christian architecture, the evidence of such mental development and decline in Europe from the tenth to the seventeenth century; but remember that my 
power or any one else's, to show you truths of this kind, must depend entirely on the degree of sympathy you have in yourselves with what is decorous and generous. I use both these words advisedly, and distinctively, for every high quality of art consists either in some expression of what is decent,--becoming, -or disciplined in character, or of what is bright and generous in the forces of human life.

I need not say that I fear no want of such sympathy in you; yet the circumstances in which you are placed are in many respects adverse to it.

237. I find, on returning to the University after a period of thirty years, the scope of its teaching greatly extended, the zeal of its masters certainly undiminished; and, as far as I can judge, the feeling of the younger members of the University better, and their readiness to comply with all sound advice, greater, than in my time. What scandals there have been among us, I think have been in great part accidental, and consequent chiefly on the intense need for excitement of some trivial kind, which is provoked by our restless and competitive work. In temper, in general amenability to right guidance, and in 
their sense of the advantages open to them, more may now be hoped than ever yet from the students of Oxford-one thing only I find wanting to them altogether-distinctness of aim.

238. In their new schools of science they learn the power of machinery and of physical elements, but not that of the soul; I am afraid, in our new schools of liberal religion they learn rather to doubt their own faiths than to look with patience or respect on those of others ; and in our new schools of policy, to efface the canons of the past, without having formed any distinct conception of those which must regulate the institutions of the future.

239. It is therefore a matter of very deep rejoicing to me that, in bringing before your examination the best forms of English art, I am necessarily leading you to take interest in the history of your country at the time when, so to speak, it became England. You see how, in every college which is now extending or renewing its buildings, the adopted style is approximately that of the thirteenth century ;-it being felt, and rightly felt, by a continuaily-extending instinct, that only then the national mind had unimpaired power of ideal conception. Whatever 
else we may have advanced in, there is no dispute that, in the great arts, we have steadily, since that thirteenth century, declined: and I have, therefore, since accepting this professorship, partly again taken up my abandoned idea of writing the story of that century, at least in England; of writing it, or, at all events, collecting it, with the help of my pupils, if they care to help me. By myself, I can do nothing; yet I should not ask them to help me if I were not certain that at this crisis of our national existence the fixing the minds of young and old upon the customs and conception of chivalry is the best of all moral education. One thing I solemnly desire to see all children taught-obedience; and one to all persons entering into life-the power of unselfish admiration.

240. The incident which I have related in my fourth lecture on sculpture, seen by me last year on the bridge of Wallingford, is a sufficient example of the courtesies in which we are now bringing up our peasant children. Do you think that any science or art we can teach them will make them happy under such conditions? $\mathrm{Nay}$, in what courtesy or in what affection are we even now carefully training ourselves;- 
above all, in what form of duty or reverence to those to whom we owe all our power of understanding even what duty or reverence means? I warned you in my former lecture against the base curiosity of seeking for the origin of life in the dust; in earth instead of heaven : how much more must I warn you against forgetting the true origin of the life that is in your own souls, of that good which you have heard with your ears, and your fathers have told you. You buy the picture of the Virgin as furniture for your rooms; but you despise the religion, and you reject the memory, of those who have taught you to love the aspect of whatsoever things and creatures are good and pure : and too many of you, entering into life, are ready to think, to feel, to act, as the men bid you who are incapable of worship, as they are of creation ;- whose power is only in destruction: whose gladness only in disdain; whose glorying is in their shame. You know well, I should think, by this time, that I am not one to seek to conceal from you any truth of nature, or superstitiously decorate for you any form of faith ; but I trust deeply -(and I will strive, for my poor part, wholly, so to help you in steadfastness of heart)- 
that you, the children of the Christian chivalry which was led in England by the Lion-Heart, and in France by Roland, and in Spain by the Cid, may not stoop to become as these, whose thoughts are but to invent new foulness with which to blaspheme the story of Christ, and to destroy the noble works and laws that have been founded in His name.

Will you not rather go round about this England and tell the towers thereof, and mark well her bulwarks, and consider her palaces, that you may tell it to the generation following? Will you not rather honour with all your strength, with all your obedience, with all your holy love and never-ending worship, the princely sires, and pure maids, and nursing mothers, who have bequeathed and blest your life ?-that so, for you also, and for your children, the days of strength, and the light of memory, may be long in this lovely land which the Lord your God has given you.

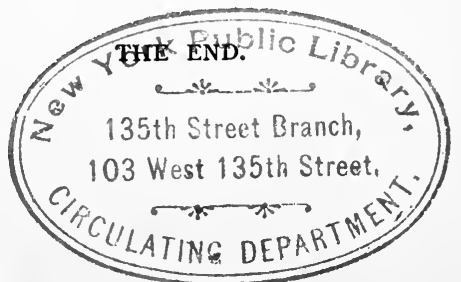





